\title{
ROLA RZEMIOSLA SKANDYNAWSKIEGO W DZIEJACH GOSPODARCZYCH WCZESNOŚREDNIOWIECZNEJ EUROPY W ŚWIETLE BADAŃ METALOZNAWCZYCH NOŻY ŻELAZNYCH*
}

\author{
THE ROLE OF SCANDINAVIAN CRAFTSMANSHIP IN THE ECONOMIC \\ HISTORY OF EARLY-MEDIEVAL EUROPE IN THE LIGHT \\ OF METAL SCIENCE RESEARCH INTO IRON KNIVES
}

\begin{abstract}
Władysław Łosiński has never been published before. It has been printed based on an original typescript of a research paper entitled as above, completed by W. Łosiński in November 1995. The typescript is stored in the archive of the Centre for Medieval Archaeology of the Baltic States at the Institute of Archaeology and Ethnology of the Polish Academy of Science in Szczecin, W. Łosiński's alma mater. The decision to print the article stemmed from its high scholarly value. The fact that the author failed to finish the editorial work on the text has been disregarded. Therefore, the planned map of the finds is missing while the list of literature on the subject is incomplete. Since the editors could not follow the author's precise bibliographic guidelines, the bibliography has not been supplemented. The text's proof-reading has been limited to necessary editorial corrections which are intended by the editors to make the reading easier (punctuation, spelling mistakes, correcting
\end{abstract}

* Od Redakcji: niniejszy artykuł prof. Władysława Łosińskiego nie był dotąd publikowany. Podstawą druku jest maszynopis autorskiego opracowania naukowego o wyżej wymienionym tytule, ukończony przez W. Losińskiego w listopadzie 1995 r. Maszynopis przechowywany jest w archiwum Ośrodka Archeologii Średniowiecza Krajów Nadbałtyckich Instytutu Archeologii i Etnologii PAN w Szczecinie (nr inw. 150/95), czyli w macierzystej placówce naukowej W. Łosińskiego. O druku artykułu przesądziły jego bardzo wysokie walory naukowe. Pominięto w tym przypadku fakt, iż Autor nie ukończył prac redakcyjnych nad tekstem, w związku z czym brakuje mapy znalezisk, która była planowana, a wykaz literatury cytowanej w tekście jest niepełny. Ponieważ Redakcja nie dysponowała precyzyjnymi wskazówkami bibliograficznymi Autora, wykazu literatury nie uzupełniono. Korektę tekstu ograniczono do niezbędnych poprawek edytorskich, które w zamyśle Redakcji mają ułatwić lekturę artykułu (interpunkcja, usunięcie tzw. literówek, wprowadzenie poprawnych zapisów tytułów cytowanych prac). W publikowanej wersji artykułu zaznaczono partie tekstu, których nie można było odczytać w maszynopisie, jak również partie wyrazów odtworzone na podstawie zachowanych fragmentów. Maszynopis artykułu przekształcił w wersję cyfrową mgr Andrzej Krzyszowski z Muzeum Archeologicznego w Poznaniu, któremu wyrażamy w tym miejscu serdeczne podziękowanie za pomoc. Kolega Krzyszowski (współpracujący z prof. W. Łosińskim w przygotowaniu do druku monografii wczesnośredniowiecznego cmentarzyska kurhanowego w Świelubiu pod Kołobrzegiem) przypomniał też Redakcji o istnieniu maszynopisu niniejszego artykułu. 
the titles of the quoted works etc.). In the published version of the article, the editors marked parts of illegible text in the typescript and parts of words reconstructed on the basis of the preserved fragments. At the beginning of the early Middle Ages, many countries of the former Barbaricum initiated farfetched changes in the smithing technology. The changes are most spectacularly demonstrated in the emergence (at least on a large part of the area) and, more importantly, dissemination of welding iron and steel, a difficult procedure requiring a good command of the smith craft. The technology represents the top achievement of the then smithing. One variant calls for special attention, namely the technology of three-layer welding of iron and steel. In Russian literature on the subject it is referred to as the three-layer package; in Western and Central-European literature it is sometimes called the "sandwich technique". It was applied mainly in production of tools, especially knives. It consisted in combining a centrally located steel interlayer that formed the blade, with lateral layers of malleable iron.

Metal science research, carried out on iron historic objects, unfortunately not always conducted on a large enough scale, suggests that the popularisation of the method of welding iron and steel in the early Middle Ages, did not encompass European countries to the same degree. In the western part of Europe, the technique has been identified in England, especially the east coast (York). On the other hand, in northern, central and eastern Europe they are represented by numerous collections from countries which, in the early Middle Ages, were parts of the sub-continental, Baltic economic zone. Outside of Scandinavia, it included the northern part of the western Slavic domain and, further on, the area inhabited by the Balts and the seaside Finns plus the vast terrain of northern Rus with the Merya people and Ugro-Finnish tribes in the east. In the $9^{\text {th }}-11^{\text {th }}$ centuries, this vast territory was of special interest to Scandinavians, both on the western and the eastern route of their migration. Perhaps they should be recognised as the people in charge of propagating this method of tool production in this vast area, inhabited by various peoples representing diverse cultural influences and different manufacturing traditions.

Keywords: Europe, Scandinavians, early Middle Ages, economy, smith craft, iron knives, metal science research, "sandwich" technology.

U progu wczesnego średniowiecza w wielu krajach dawnego Barbaricum zostały zapoczątkowane daleko idące zmiany w technologii wytwórczości kowalskiej. Ich najbardziej spektakularnym wyrazem było pojawienie się, co najmniej na znacznej części tego obszaru, a przede wszystkim upowszechnienie się zgrzewania żelaza i stali, zabiegu o znacznej skali trudności, wymagającego dobrego opanowania kunsztu rzemiosła kowalskiego. Była to technologia reprezentująca szczytowe osiągnięcie ówczesnego kowalstwa. Szczególną uwagę zwraca jeden z jej wariantów, a mianowicie technika trójwarstwowego zgrzewania żelaza i stali, w literaturze rosyjskiej znana pod mianem trójwarstwowego pakietu, a w literaturze zachodnio- i środkowoeuropejskiej określana niekiedy terminem ,sandwichtechnique". W opracowanym przez nas schemacie produkcji noży wczesnośredniowiecznych ten sposób zgrzewania dwóch materiałów o różnej zawartości węgla zaliczono do typu IV:A:2 (por. załącznik nr 1). Technikę te stosowano głównie w produkcji narzędzi, w tym zwłaszcza noży. Polegała ona na łączeniu centralnie umieszczonej wkładki stalowej, tworzącej ostrze, z bocznymi warstwami żelaza kowalnego. Był to niezmiernie efektywny sposób produkcji, zapewniający z jednej strony dużą twardość ostrza, zachowującego niezmiennie swe właściwości aż po całkowitą destrukcję narzędzia, z drugiej zaś sporą elastyczność wyrobu, dzięki bocznym nakładkom wykonanym z miękkiego, plastycznego żelaza. Metoda ta gwarantowała ponadto spore oszczędności w zużyciu wysokojakościowej, zawsze trudno dostępnej stali. Ten sposób zgrzewania żelaza i stali, o starej genezie i ro- 
dowodzie, w okresie wpływów rzymskich i u schyłku starożytności znany w głównych centrach cywilizacyjnych ówczesnej Europy ${ }^{1}$ we wczesnym średniowieczu stał

${ }^{1} \mathrm{Na}$ temat pojawienia i rozprzestrzeniania się umiejętności zgrzewania żelaza i stali w kowalstwie europejskim patrz zbiorczo Pleiner 1962, s. 124 i n. Pierwsze przykłady wyrobów zgrzewanych, w tym również wykonanych w technice sandwich, znane są już okresu halsztackiego (Piaskowski 1959, s. 204, 207; 1969a, s. 346, tab. 4; 1972, s. 76-77). Na obszarze rozsiedlenia plemion celtyckich częściej spotyka się je dopiero w okresie późnolateńskim, i to tylko na niektórych terenach, wchodzących w skład tego kręgu kulturowego (por. zwłaszcza Piaskowski 1961, s. 88 i n.; 1965, s. 264 i n.; 1970, s. 387 i n.; Schaaber 1963, s. 129 i n.; Schulz, Pleiner 1965; Spehr 1971; Emmerling 1972, s. 283, ryc. 4:1-9; Pleiner 1974, s. 461 i n.; 1982a, s. 86 i n.; Voznesenskaja 1984, s. 163 i n.; Lang 1985, s. $61 \mathrm{i}$ n.). W tym czasie stosowano różne metody zgrzewania żelaza i stali, między innymi typu IV:A:1, IV:B:2, IV:C, a także IV:A:2 [zob. załącznik nr 1 - dop. Red.], pojawiły się ponadto wyroby dziwerowane. W okresie wpływów rzymskich technologia zgrzewania żelaza i stali znalazła szerokie zastosowanie w warsztatach działających na terytorium imperium rzymskiego. Najlepiej informują o tym wyniki badań metaloznawczych licznych mieczów uznawanych za wyroby rzymskie (por. ostatnio Biborski, Kaczanowski, Kędzierski, Stępiński 1982a, s. 65 i n.; z innych licznych opracowań patrz zwłaszcza Neumann 1927, s. 241 i n.; Høeg 1952, s. 218 i n.; Schürmann 1959, s. 121 i n.; Böhne 1963, s. 227 i n.; Rosenqvist 1967/1968, s. 143 i n; Emmerling 1972, s. 296; 1978, s. 92 i n.; Piaskowski 1974b, s. 62 i n.; Biborski 1978, s. 53 i n.; Kędzierski, Stępiński 1981, s. 65 i n.; Biborski, Kaczanowski, Kędzierski, Stępiński 1982b, s. 99 i n.; Thomsen 1994, s. 281 i n.; na temat technologii produkcji innych form wyrobów patrz Pleiner 1970, s. 113 i n.). Obok prostszych metod zgrzewania, w tym i typu sandwich (wg Biborskiego, Kaczanowskiego, Kędzierskiego, Stępińskiego [1982a] typ B.I.2.1.1.), na szeroką skalę stosowano technikę dziwerowania. Miecze tej klasy znajdowały powszechny zbyt na obszarze Barbaricum (na temat eksportu broni z imperium rzymskiego patrz ostatnio Kaczanowski 1992a; 1992b, s. 171; 1994, s. 207 i n.). Niekiedy sądzi się, że część z nich mogła być tam wytwarzana przez przybyszów z rzymskich ośrodków produkcyjnych lub też przez rzemieślników germańskich, dobrze obeznanych z tajnikami warsztatu kowali rzymskich (por. ostatnio Lund Hansen 1994, s. 193 i n.; Schnurbein von 1994, s. 377-378; ze starszych prac patrz Pleiner 1975, s. 89). Badania metaloznawcze prostszych form wyrobów, w tym również narzędzi pracy, nie potwierdzają jednak sugestii o opanowaniu przez kowali działających na znacznej części Barbaricum umiejętności zgrzewania żelaza i stali. W centralnej Europie umiejętność ta była obca zarówno na terenie obecnych Niemiec wschodnich (Piaskowski 1969b, s. 301 i n.), jak i na obszarze współczesnej Polski (z obszernej literatury na ten temat patrz zwłaszcza Piaskowski 1969a, s. 332, tab. 4; 1982, s. 13 i n.; 1991, s. 41 i n.). Nieliczne przedmioty zgrzewane, w tym i dziwerowane miecze, znajdowane tam w inwentarzu kultur z okresu rzymskiego uznaje się za wyroby importowane. Jedynie w południowej Polsce można się miejscami liczyć ze stosowaniem metod utwardzania wyrobów, głównie jednak drogą nawęglania wtórnego. Przypuszcza się, że jest to spuścizna tradycji celtyckiej (Piaskowski 1964, s. 169 i n.; 1991, s. 49). Wszędzie tam pojawienie się umiejętności zgrzewania żelaza i stali przypada dopiero na wczesne średniowiecze (Piaskowski 1973, s. 29 i n.; 1974a, s. 83 i n.). Bardziej złożona jest kwestia datowania początków wprowadzenia technologii zgrzewania na terenie Skandynawii (Thålin-Bergman 1979, s. 120 i n.). Być może miało to miejsce już w okresie wpływów rzymskich, w każdym razie wyroby zgrzewane, w tym i dziwerowane miecze, znane są tam już w okresie Vendel (Thålin 1967, s. 225 i n.). Sądzi się, że miecze ze znanych znalezisk w Vendel i Valsgårde, a także kilka okazów z Gotlandii, wykonano w technice pattern-welding (Thålin-Bergman 1983, s. 157). Z bezpośrednim przejęciem dziedzictwa cywilizacji rzymskiej liczyć się głównie należy na terytorium królestwa Franków. W okresie merowińskim i wczesnokarolińskim powszechnie stosowano tam technologię zgrzewania żelaza i stali. Masowo produkowano dziwerowane miecze. Zgodnie sądzi się, że technika ta osiągnęła wówczas najwyższy poziom rozwoju. Stosowano i prostsze metody zgrzewania, w tym technikę typu sandwich (z bogatej literatury na ten temat patrz między innymi: France-Lanord 1949, s. 19 i n.; Salin 1957; Böhne, Dannheimer 1961, s. 107 i n.; Böhne 1963, s. 227 i n.; Bühler, Strassburger 1966, s. 613 i n.; Emmerling 1972, s. 296 i n.; Antejn 1973, s. 20 i n.; Piaskowski 1974a, s. 93; 1974b, s. 65; Pleiner 1975, s. 89-90). Te doskonałe wyroby, zwłaszcza broń, znajdowały szeroki zbyt w wielu krajach ówczesnej Europy. Równie wcześnie, jak w centralnej i zachodniej Europie, doszło do opanowania technologii zgrzewania żelaza i stali na jej wschodnich ru- 
bieżach. W strefie nadczarnomorskiej umiejętność tę wcześnie posiedli Scytowie (Šramko, Solncev, Fomin 1963, s. 36 i n.; Šramko, Fomin, Solncev 1970, s. 40 n.; 1971, s. 140 i n.; Voznesenskaja, Chomutova 1974, s. 180 i n.), a później Sarmaci (Šramko, Solncev, Stepanskaja, Fomin 1974, s. 181 i n.), mieszkańcy tych ziem do momentu rozsiedlenia się tam w połowie III w. [n.e. - dop. Red.] plemion kultury czerniachowskiej (Rusanova, Symonovič [red.] 1993, s. 150). W kręgu scytyjskosarmackim stosowano rozmaite techniki zgrzewania, zarówno typu 1V:C:1, jak i IV:B oraz IV:A:1-2, wydaje się jednak, że technologia ta nie była $\mathrm{w}$ tej dobie szerzej rozpowszechniona. Podobnie było również na terenie królestwa bosporańskiego (Alekseeva, Rozanova, Terechova 1994, s. 157 i n.), a także na obszarze zachodniego Kaukazu, znajdującym się w strefie oddziaływań cywilizacji rzymskiej, gdzie jednak obok wyrobów żelaznych ze stalowymi nakładkami już w IV-VI w. [n.e. - dop. Red.] pojawiły się miecze wykonane w technice dziweru (Bgažda, Terechova, Rozanova 1990, s. 184 i n.).Wyroby zgrzewane z żelaza i stali spotyka się również $\mathrm{w}$ inwentarzu kultur położonych bardziej na północ, w strefie leśnej i częściowo leśno-stepowej. W pojedynczych egzemplarzach występują one w materiałach kultury zarubinieckiej (III/II w. p. n.e.-połowa I w. n.e.), gdzie reprezentowane są głównie przez okazy typu IV:A:1 (Gopak, Chavljuk 1972, s. 90 i n.; Gopak, Šovkopljas 1983, s. 154 i n.; Gopak 1984, s. 88 i n.). Nie znaczy to jednak, aby ludność tej kultury przyswoiła sobie umiejętność zgrzewania żelaza i stali (Voznesenskaja 1972, s. 30, ryc. 7; Slavjane 1990, s. 384 i n., ryc. 84; Gurin 1982, s. 96, tab. 19). Obecność tam wyrobów zgrzewanych thumaczy się zazwyczaj kontaktami z kręgiem cywilizacji lateńskiej (Voznesenskaja 1972, s. 32; Slavjane 1990, s. 384), chociaż nie można również wykluczać wpływów scytyjsko-sarmackiego Południa, z którym związki kultury zarubinieckiej były dość silne (Slavjane 1990, s. 405 i n.; Rusanova, Symonovič [red.] 1993, s. 20 i n.). Podobne wyniki przyniosły badania metaloznawcze materiałów postzarubinieckich (Gopak, Zavernjaev 1981, s. 181 i n.). Na stanowiskach tej kultury wyroby zgrzewane mają czasami formę, która zbliża je do inwentarza kultury diakowskiej (patrz poniżej), gdzie jednak widoczne są również wpływy celtyckie (Rusanova, Symonovič [red.] 1993, s. 83). Z opanowaniem technologii, zgrzewania żelaza i stali można się natomiast liczyć w kulturze czerniachowskiej (II/III-połowa V w.), chociaż i tam odsetek wyrobów zgrzewanych nie jest wysoki (Voznesenskaja 1970, s. 34 i n.; 1972, s. 8 i n.; Gurin 1982, tab. 19; Baran, Gopak 1986, s. 68 i n.; Slavjane 1990, s. 385 i n.). Spotyka się przedmioty wykonane zarówno w technice IV: C:1, jak i IV:A:2, zaliczane przez Voznesenską do grupy wyrobów [tekst nieczytelny]. Pojawienie się tej technologii to najpewniej przede wszystkim wynik bliskich kontaktów gospodarczych z prowincjonalnorzymskimi centrami wytwórczości. Kultura czerniachowska jest w każdym razie przykładem jednej z nielicznych kultur na obszarze Barbaricum, gdzie w okresie wpływów rzymskich stosowano w miejscowych warsztatach kowalskich zgrzewanie żelaza i stali. Wyroby wykonane w tej technologii występują również na stanowiskach kultury typu kijowskiego (II/III-połowa V w.). Należą one jednak do rzadkości, spotyka się je między innymi w grupie noży (Rusanova, Symonovič [red.] 1993, s. 120). Ich obecność tłumaczyć być może należy kontaktami ludności tej kultury z kręgiem czerniachowskim. Bardziej złożona jest sprawa genezy technologii zgrzewania żelaza i stali na terytorium rozsiedlenia plemion kultury diakowskiej, wiązanej zarówno z Ugrofinami, jak i - zwłaszcza w późniejszej fazie rozwoju tej kultury - z Bałtami (Dubynin 1970, s. 54 i n., 94 i n.; D’jakovskaja kul'tura 1974, s. 76 i n., 189 i n.; Sedov 1987, s. 68-69). Na stanowiskach datowanych na 1 . połowę i początki 2. połowy I tysiąclecia n.e. wyroby zgrzewane występują tam w dość długich seriach (Voznesenskaja 1965, s. 129 i n.; 1970b, s. 192 n.; Chomutova 1978 , s. 62 i n.). Są one reprezentowane przez okazy wykonane przede wszystkim w technice IV:A:1, rzadziej IV:B:2 i 1V:C:1, wyjątkowo IV:A:2. Te ostatnie spotyka się wyłącznie na stanowiskach chronologicznie najmłodszych, może zatem pochodzą one dopiero z IX w. Sądzi się, że plemiona zamieszkujące zachodnią część terytorium kultury diakowskiej osiągnęły wyższy poziom w rozwoju technologii kowalstwa. Byłaby to zatem głównie zasługa żywiołu bałtyjskiego. Według niektórych badaczy Bałtowie, zasiedlający południowo-wschodnie wybrzeża Bałtyku, wcześnie mieli opanować umiejętność zgrzewania żelaza i stali, jeszcze w okresie wpływów rzymskich, a zwłaszcza u schyłku starożytności w dobie wędrówek ludów (Stankus 1970, s. 57 i n.; 1975, s. 43-44; 1984, s. 135 i n.; 1985, s. 133 i n.; 1988, s. 65 i n.). Badania polskie (Piaskowski 1981, s. 11 i n.) nie potwierdziły - jak dotąd - tej sugestii, wykazały jedynie, że Bałtowie wcześnie podjęli produkcję stali otrzymywanej w procesie dymarkowym z wytopu rud wysokofosforowych (Piaskowski 1982, s. 18 i n.; 1991, s. 49 i n.). Sprawa nie jest zatem do końca jasna, a trudności z precyzyjnym datowaniem materiałów bałtyjskich nie ułatwiają rozwiązania tej kwestii (por. tu uwagi Pleinera 1983). 
się jednym ze standardów technologicznych, powszechnie stosowanych w wytwórczości kowalskiej.

Jak wynika z dotychczas przeprowadzonych badań metaloznawczych zabytków żelaznych, nie wszędzie podejmowanych niestety na zadowalającą skalę, umasowienie się we wczesnym średniowieczu tej metody zgrzewania żelaza i stali nie objęło w równym stopniu ogółu krajów europejskich. Już pierwszy ogląd mapy ze skartowanymi nożami wykonanymi w technice sandwich ukazuje skupianie się ich na obszarze o dość wyraźnie zarysowanych granicach. W zachodniej części Europy spotyka się je w Anglii, zwłaszcza na jej wschodnich wybrzeżach (York), natomiast w Europie Północnej, Środkowej i Wschodniej są one reprezentowane przez liczne kolekcje pochodzące z krajów wchodzących we wczesnym średniowieczu w skład subkontynentalnej, nadbałtyckiej strefy gospodarczej. Poza Skandynawią obejmowała ona północną część Słowiańszczyzny zachodniej, a dalej terytoria zamieszkane przez Bałtów i Finów nadmorskich, a także rozległe obszary Rusi północnej po Wes', Merię i Murom [plemiona ugrofińskie - dop. Red.] na wschodzie. Wszędzie tam badania metaloznawcze potwierdziły powszechne występowanie noży zgrzewanych z żelaza i stali, wykonanych w technice trójwarstwowego pakietu ${ }^{2}$.

To rozległe terytorium w IX-XI w. znalazło się w strefie szczególnych zainteresowań Skandynawów, zarówno na zachodnim, jak i na wschodnim szlaku ich wędrówki (por. ostatnio Wikinger 1992; ze strony nauki polskiej patrz Leciejewicz 1979). Może im zatem należałoby przypisać upowszechnienie się na tym olbrzymim obszarze, zasiedlonym przez różne ludy o własnym odrębnym piętnie kulturowym i o odmiennych tradycjach wytwórczości, tej metody produkcji narzędzi.

Z powyższego przeglądu wynika, że w późnym okresie przedrzymskim i w okresie rzymskim aż po schyłek okresu wędrówek ludów technologię zgrzewania żelaza i stali, pomijając nie do końca jeszcze jasną sytuację w środowisku bałtyjskim, stosowano przede wszystkim w głównych centrach cywilizacyjnych ówczesnej Europy. W pierwszych wiekach n.e. wiodąca była rola imperium rzymskiego. Na obszarze Barbaricum z przyswojeniem sobie tej umiejętności można liczyć się zaledwie na terenie rozsiedlenia plemion kultury czerniachowskiej i być może również w Skandynawii. Podobnie mogło być także na innych ziemiach, położonych zwłaszcza w bezpośrednim sąsiedztwie limesu. Nigdzie tam jednak nie stwierdzono dominacji jednej z licznych technik zgrzewania, wszędzie stosowano równolegle różne jej warianty, w tym również typu IV:A:2. Ze standaryzacją na tym odcinku mamy dopiero do czynienia w okresie wczesnego średniowiecza, kiedy to technika sandwich opanowała warsztat ówczesnego kowala w znacznej części Europy. U schyłku starożytności z bezpośrednim przejęciem dziedzictwa rzymskiego należy liczyć się przede wszystkim w krajach powstałych na gruzach cesarstwa rzymskiego.

2 Ostatnio por. Pleiner 1993, s. 84. Terytorialnie ograniczony zasięg masowego występowania noży wykonanych $\mathrm{w}$ technice sandwich dobrze ilustrują materiały pochodzące $\mathrm{z}$ tych krajów, w których badania metaloznawcze przeprowadzono na szerszą skalę. Do nich zaliczają się zwłaszcza Czechy i Słowacja. Potwierdzona tam została znajomość trójwarstwowego zgrzewania (Pleiner 1967, s. 81; 1993, s. 79-80), technologii tej nie stosowano jednak w produkcji noży (Pleiner, Plzák, Quadrat 1956, s. 317 i n.; Piaskowski 1964b, s. 134 i n.; Pleiner 1967, s. 83 i n.; 1969, s. 558 i n.; 1979a, s. 245 i n.; 1979b, s. 396 i n.; 1982b, s. 274 i n.; 1989, s. 77 i n.; 1993, s. 74 i n.). Dość podobne wyniki przyniosły badania metaloznawcze zabytków żelaznych pochodzących z wczesnośredniowiecznej Bułgarii (patrz ostatnio Mamzer 1988, tab. VII, VIII). 
Taką hipotezę, czasami jedynie domysł, sformułowano już, i to nie tylko w nauce polskiej (por. ostatnio Pleiner 1993, s. 84). Jeżeli tak było w istocie, to Normanowie byliby nosicielami jednej z ważniejszych zdobyczy ówczesnej techniki i technologii, ważącej na poziomie tak istotnej w gospodarce gałęzi produkcji, jaką było rzemiosło kowalskie. Dla problematyki kształtowania się oblicza gospodarczego europejskiego wczesnego średniowiecza jest to kwestia na tyle istotna, iż warto ją przetestować na podstawie obecnie dostępnych materiałów. Zasób źródeł jest jednak ogromny (chociaż terytorialnie bardzo nierównomiernie rozłożony), stąd też dla potrzeb niniejszego artykułu ograniczymy się do oglądu materiałów z trzech szczególnie ważnych rejonów, a mianowicie z samej Skandynawii oraz z obszaru Rusi północnej (wraz z jej gospodarczymi pertynencjami) na wschodzie i z Anglii za zachodzie. W strefie naszego zainteresowania znajdują się zatem poza macierzystymi terenami rozsiedlenia Normanów, dwa skrajnie położone rejony, ku którym kierowały się wyprawy wikingów. Problem ten przedyskutujemy na przykładzie noży, wszędzie masowo znajdowanych na stanowiskach wczesnośredniowiecznych, najczęściej też poddawanych analizom metalograficznym.

W krajach skandynawskich badania metaloznawcze zabytków żelaznych mają już odległą tradycję. Dopiero jednak w ostatnich latach podjęto tam bardziej systematyczne prace, obejmujące dłuższą serię noży. W porównaniu do skali podobnych badań prowadzonych w Rosji i Polsce, częściowo także na Litwie i Łotwie, są to dopiero początki realizacji szerszego programu badań metaloznawczych tej kategorii zabytków. Nie ułatwia to podjęcia się zadania pełniejszej oceny stanu technologii kowalstwa wczesnośredniowiecznych Normanów, punkt startu naszych uwag nie jest zatem zbyt korzystny. To, co jednak już dziś wiadomo na ten temat, warto wstępnie podsumować ${ }^{3}$.

Większość materiałów pochodzi z terenu Szwecji. Znana stamtąd seria obejmuje ponad 50 noży wybranych do badań metaloznawczych z 5 stanowisk archeologicznych, w tej liczbie $\mathrm{z}$ tak ważnych dla archeologii skandynawskiej zespołów osadniczych, jak Helgö, Birka i Eketorp, skąd pochodzi zdecydowana większość noży uwzględnionych $\mathrm{w}$ naszej analizie. Kolekcję tę uzupełniają pojedyncze okazy z wyspy Bornholm (Lousgaard) oraz 8 egzemplarzy z Haithabu, założonego nad odnogą [rzeki - dop. Red.] Schlei u nasady Półwyspu Jutlandzkiego.

Na szczególną uwagę zasługuje zbiór 15 noży z wyspy Helgö (Tomtlund 1973, s. 42 i n.; Modin, Pleiner 1978, s. 81 i n.), położonej u ujścia jeziora Mälaren, w środkowej Szwecji. Odkryto tam niezmiernie interesujący zespół osadniczy, składający się z kilku grup domostw i znajdujących się w ich sąsiedztwie cmentarzysk (Helgö I-X: 1961-1986). Początki osady sięgają schyłku starożytności. W okresie

\footnotetext{
3 Patrz też na niżej cytowaną literaturę. Ze strony nauki polskiej stanowisko takie zajął ostatnio J. Piaskowski. Z tą sugestią autor niniejszych słów zapoznał się po raz pierwszy na posiedzeniu naukowym Komisji Archeologicznej Poznańskiego Towarzystwa Przyjaciół Nauk w dniu 5.11.1987 r.
} 
wędrówek ludów i w starszych fazach okresu Vendel był to już liczący się punkt osadniczy. Osada egzystowała także w młodszych fazach okresu Vendel oraz w okresie wikińskim aż do początku XI w. (por. Lundström 1968, s. 278 i n.; Jankuhn 1971, s. 18 i n.; Holmqvist 1974, s. 21 i n.; 1976a, s. 127 i n.; 1976b, s. 35 i n.; Ellmers 1985, s. 38-39; ze strony nauki polskiej patrz Leciejewicz 1963, s. 333 i n.; 1976, s. 40, 115). Do niedawna zespół ten uznawano za przykład wczesnej formy osady rzemieślniczo-targowej, poprzedzającej powstanie ośrodka wczesnomiejskiego w Birce. Dziś pogląd ten nie znajduje już uznania, daleko jednak jeszcze do pełnego wyjaśnienia funkcji i roli Helgö w dziejach, zwłaszcza gospodarczych, wczesnośredniowiecznej Skandynawii (por. tu instruktywny przegląd rozmaitych opinii na ten temat w pracy Lundström [red.] 1988). Przypuszcza się, że poszczególne zespoły domostw pochodzą z różnych faz rozwoju osady. W V-VI w. najbardziej aktywne miało być skupisko wschodnie, później zaś punkt ciężkości osady przesunął się w kierunku zachodnim. W VII-VIII w. centrum Helgö wiąże się z grupą środkową, a w okresie wikińskim ze skupiskiem zachodnim (Clarke, Ambrosiani 1991, s. 68 i n.). Sądzi się, że tej translokacji towarzyszyły zmiany w charakterze osiedla, w zasadzie jednak zawsze mieściło się ono w strukturze typowej dla osadnictwa wiejskiego. W sposobie zabudowy, a przede wszystkim w rozległości osady i liczebności jej mieszkańców, Helgö odbiegało od modelu wczesnych osad rzemieślniczo-handlowych. Nie była to jednak osada o „czysto” wiejskim charakterze. Przeczy temu znaleziony tam niezmiernie bogaty i zróżnicowany inwentarz zabytkowy. Imponująca jest zwłaszcza liczba wyrobów o obcej proweniencji, wywodzących się z różnych, niekiedy bardzo odległych krajów i ośrodków produkcji. Do znalezisk powszechnych należą wytwory związane z kręgiem merowińskim i wczesnokarolińskim, spotyka się także przedmioty o rodowodzie anglosaskim, aryjskim i bałtyjskim. Reprezentowane są również dzieła rzemiosła kultur Wschodu. Do odkryć unikatowych w środowisku północnoeuropejskim zalicza się zwłaszcza indyjski posążek Buddy oraz brązowy czerpak pochodzenia zapewne koptyjskiego. Niezmiernie długa jest ponadto lista znalezisk monetarnych (Helgö X: 1986). Ze starszej fazy rozwoju Helgö na szczególną uwagę zasługuje bogata kolekcja solidów bizantyjskich. Z późniejszej doby pochodzą emisje europejskie, $w$ tym i nordyjskie, a przede wszystkim monety arabskie związane głównie z najstarszą falą dopływu srebra kufickiego na wybrzeża szwedzkie, przypadającą na schyłek VIII i początek IX w. do około 833 r. (Łosiński 1988, s. 116 i n.). Kilka zaledwie dirhemów wiąże się z kolejnym strumieniem kruszcu orientalnego z około połowy IX stulecia, brak tu natomiast emisji samanidzkich, tak licznie spotykanych w zespołach birczańskich (Birka I: 1940-1943; Linder Welin 1973, s. 197 i n.; Randsborg 1980, ryc. 92). Poświadczone są także kontakty ze słowiańskim wybrzeżem Bałtyku, skąd docierały między innymi naczynia typu Feldberg (Helgö I: 1961, s. 184, tabl. 59; na temat najstarszej ceramiki słowiańskiej w środowisku skandynawskim patrz ostatnio Callmer 1988, s. 654 i n.; tamże również o znaleziskach w Helgö). Wiążą się one, podobnie jak wspomniane powyżej monety arabskie oraz 
emisje europejskie, z późniejszą fazą rozwoju osiedla [w Helgö - dop. Red.], przypadającą na schyłek okresu Vendel i początki kresu wikińskiego.

W Helgö równie liczne są ślady działalności produkcyjnej, w tym zwłaszcza obróbki metali kolorowych i żelaza. Sądzi się, że te dziedziny wytwórczości rozwijały się przede wszystkim w okresie wędrówki ludów i w starszych fazach okresu Vendel, później zaś skala produkcji miała ulec znacznemu ograniczeniu, czemu nie towarzyszył jednak spadek liczby importów (por. tu zwłaszcza rozprawy Callmera $\mathrm{i}$ Lamma w pracy Lundström [red.] 1988, s. 31 i n., s. 89 i n.). Obok tygli odlewniczych, masowo znajdowane są żużle żelazne, w tej liczbie duże okazy w kształcie czaszy (Helgö X: 1986, s. 131 i n.), stanowiące odpowiedniki form zaliczanych przez J. Piaskowskiego (1987, s. 331 i n.) do typu II. Zwraca uwage wyjątkowo niska zawartość fosforu w żużlach, mieszczącego się w przedziale od 0,13 do $0,37 / 0,47 \mathrm{P}_{2} 0_{5}$. Wskazywałoby to na pozyskiwanie żelaza między innymi z wysokojakościowych rud niskofosforowych, które w Skandynawii były dość powszechnie eksploatowane aż do schyłku okresu wikińskiego (Arrhenius 1959, s. 26 i n., tab. 8; ten sam autor podaje jednak, że wśród wyrobów z Helgö [s. 28 i n.] zdecydowanie przeważają przedmioty wykonane z żelaza wysokofosforowego). Do znalezisk szczególnie interesujących należą grzywny żelazne różnego typu i pochodzenia (Helgö V/1: 1978, s. 30 i n.), jedne charakterystyczne dla obszaru Szwecji północnej, inne zaś rozpowszechnione zwłaszcza w prowincji Småland i na Olandii (por. szerzej na ten temat Müller-Wille 1980, s. 129 i n.; patrz też Helgö X: 1986, s. 146 i n.). Handel żelazem był w każdym razie zjawiskiem powszechnym. Wśród grzywien spotyka się okazy o podwyższonej zawartości niklu (Hansson, Modin 1973, s. 5 i n.; Thålin 1973, s. 31 i n.). Rudy o takim składzie znane są z północnej Szwecji.

Ogół przedstawionych powyżej danych wskazuje na wyjątkową pozycję osiedla, które słusznie chyba wiąże się ze środowiskiem możnowładczym. Być może była to posiadłość władców wczesnopaństwowej organizacji Swewów, co dobrze thumaczyłoby znaczną aktywność osady w sferze produkcji i wymiany (Clarke, Ambrosiani 1991, s. 71). Tę liczącą się pozycję Helgö utrzymało najpewniej do początku okresu wikińskiego, nie później jednak niż do około połowy IX stulecia, jak wynikałoby $\mathrm{z}$ datowania monet arabskich ${ }^{4}$.

${ }^{4}$ Charakter osady w Helgö nie przystaje do modelu najstarszych osiedli rzemieślniczo-handlowych zakładanych od schyłku VII, a zwłaszcza od początku VIII w., zarówno na obszarze rozsiedlenia Normanów, jak i na terytorium Słowian nadbałtyckich. Początkowo były to zazwyczaj osady sezonowo jedynie zamieszkane, wcześnie jednak powstawały również trwale zasiedlone osiedla, skupiające wyspecjalizowanych rzemieślników i kupców. Dobrych przykładów tego typu wczesnych, nieagrarnych aglomeracji dostarczyły badania przeprowadzone w Ribe (Jensen 1991) i Åhus (Callmer 1988, s. 658, 660) w środowisku nordyjskim oraz w Dierkow (Warnke 1988, s. 69 i n.) i Gross Strömkendorf (Wietrzichowski 1993) na obszarze północnej Połabszczyzny (por. tu także Callmer 1994, s. 76 i n.; Łosiński 1995, s. 79 i n.). Wszędzie powstanie tych najstarszych punktów wymiany, niemieszczących się $\mathrm{w}$ tradycyjnych strukturach przestrzennych osadnictwa, wiązało się najpewniej z ekspansją gospodarczą Fryzów. Wcześnie jednak nosicielami tej idei stali się Skandynawowie, dzięki którym doświadczenia te zostały przeniesione na szlakach ich wędrówek do różnych krajów ówczesnej Europy. 
W tym kontekście tym bardziej interesujące są wyniki badań metaloznawczych noży. Niestety nie do końca jasna jest ich pozycja chronologiczna, najpewniej jednak większość z nich pochodzi z okresu Vendel i z początku okresu wikińskiego.

Zwraca uwage przede wszystkim spora rozmaitość stosowanych wówczas metod produkcji noży. Niektóre z nich wykonano z jednego kawałka metalu, inne natomiast zgrzewano z kilku warstw surowca. Wśród pierwszych spotyka się okazy wykute z kilku warstw surowca. Wśród pierwszych spotyka się okazy wykute zarówno z żelaza, jak i ze stali, drugie zaś wykonano przez zgrzanie prętów o podobnej lub znacznie różniącej się zawartości węgla. Jedynie te ostatnie to wyroby zgrzewane z żelaza i stali, stanowiące zaledwie nieco powyżej 25\% badanego zbioru. W odsetku $20 \%$ są one reprezentowane przez szczególnie interesujące nas tu noże z centralnie umieszczoną wkładką stalową ujętą przez dwie boczne warstwy żelaza (Tomtlund 1973, noże nr 4 i 5; Modin, Pleiner 1978, nóż nr 11355). Spotyka się wśród nich okazy o wydłużonym trzpieniu, niezmiernie charakterystyczne dla środowiska skandynawskiego począwszy od okresu merowińskiego (Petersen 1951, s. 188 i n.). Do tej grupy technologicznej nawiązuje nóż nr 11 (Tomtlund 1973, ryc. 2), zgrzany jednak z trzech warstw stali (wariant typu II:C:2), [co - dop. Red.] nie miało - jak się powszechnie sądzi w literaturze metaloznawczej - racjonalnego uzasadnienia. Można zatem sądzić, że w środkowej Szwecji $\mathrm{w}$ interesującym nas tu okresie technika typu sandwich znajduje się dopiero w fazie pierwszych prób i eksperymentów, nie zawsze w pełni udanych. Dotyczyłoby to w każdym razie tej części wytwórczości kowalskiej, która była nastawiona na produkcję wyrobów powszechnego użytku, do których zaliczały się niewątpliwie noże, potrzebne w każdym gospodarstwie domowym i w warsztacie rzemieślniczym.

Równolegle stosowano i inne techniki zgrzewania. Wiele tu przykładów indywidualnych rozwiązań, z których jedynie niektóre stały się później powszechnie obowiązującymi standardami technologicznymi. Dotyczy to zwłaszcza okazów z ostrzami stalowymi w postaci klinowatych wkładek (Tomtlund 1973, nóż nr 1), lub też nakładek (tamże, nóż nr 10), zgrzanych z żelaznym korpusem narzędzia. I wśród tych noży spotyka się jednak egzemplarze z grzbietem wykonanym ze stali (nóż nr 10). Całościowo zatem sytuacja była mało stabilna, okres ten charakteryzowała wielość technik produkcji noży, chociaż były to jednocześnie czasy, w których pojawiły się rozwiązania technologiczne, później masowo stosowane w warsztacie w pełni profesjonalnego rzemieślnika.

Ten etap umasowienia się techniki typu sandwich dobrze ilustrują wyniki badań metaloznawczych noży z osiedla wczesnomiejskiego w Birce, założonego na wyspie Björke, we wschodniej części jeziora Mälaren, najpewniej już - jak się ostat-

Natomiast model typu Helgö jest może zaczynem nieagrarnych struktur osadniczych powstałych z inicjatywy władzy książęcej. W Norwegii wiele późniejszych miast rozwinęło się z folwarku książęcego (ze strony nauki polskiej patrz Urbańczyk 1994, s. 114 i n.). 
nio sądzi - około 750 r. (tradycyjne początki Birki datuje się około 800 r.). W okresie wikińskim był to najbardziej liczący się ośrodek życia gospodarczego w środkowej Szwecji, ważne centrum rzemiosła i wymiany, często odwiedzane przez obcych kupców (Birka I-V; 1938-1989; Ambrosiani, Arrhenius, Danielsson, Kyhlberg, Werner 1973; Holmquist Olausson 1993; w ostatnich latach podjęto ponowne badania w Birce, patrz Ambrosiani, Clarke [red.] 1992; ze strony nauki polskiej por. Leciejewicz 1979, s. 117 i n.). Przebywali tam najpewniej także przybysze ze słowiańskich wybrzeży Bałtyku, chociaż nie do końca jasny jest ich status społeczny. Mogli to być zarówno niewolni, jak i rzemieślnicy wędrowni i kupcy. W 2. połowie X w., być może już w latach 970. [w 70. latach X w. dop. Red.], Birka utraciła swe funkcje gospodarcze, a później została opuszczona. W XI stuleciu jej miejsce zajęła pobliska Sigtuna.

Z Birki dysponujemy szczegółowymi informacjami na temat sposobu wykonania 12 noży (Arrhenius 1989, s. 79 i n.). Pochodzą one zarówno z osady wczesnomiejskiej (svarta jorden), jak i z rozpościerających się wokół niej cmentarzysk. $\mathrm{Z}$ serii tej zaledwie jeden nóż, odkryty na terenie osiedla, został wykuty z jednego kawałka metalu; była to stal o strukturze perlitu. Pozostałe egzemplarze to wyroby zgrzewane z żelaza i stali, stanowiące łącznie ponad $90 \%$ kolekcji. Zdecydowanie najliczniejsze są noże wykonane $\mathrm{w}$ technice sandwich $\mathrm{z}$ centralnie umieszczoną wkładką stalową (IV:A:2). Są one reprezentowane przez 75\% ogółu okazów. Jest wśród nich okaz wybrakowany, w którym warstwę stali zastąpiono prętem żelaznym, chociaż mogło tu dojść także do odwęglenia stali w czasie ciałopalenia, jak skłonna jest sądzić B. Arrhenius (1989, s. 81). Interesujące jednak, że nóż ten pochodzi z grobu (nr 618) o bardzo wczesnej metryce, datowanego na koniec VIII lub na około 800 r. (Müller-Wille 1985, s. 467), może zatem był to raczej produkt wykonany przez kowala przyswajającego sobie dopiero skomplikowane reguły reżimu trójwarstwowego zgrzewania żelaza i stali. Pozostałe noże tej grupy w sposobie wykonania reprezentują klasyczne przykłady techniki typu sandwich, przy czym czasami jednak obok jednorodnej, średnio- lub wysokowęglowej stali używano także metalu o strukturze pasmowej. W każdym razie w okresie funkcjonowania Birki ten sposób produkcji był już powszechnie obowiązującym standardem technologicznym. Potwierdzają to również makroskopowe obserwacje szeregu noży, wśród których liczne okazy, zwłaszcza o prostym tylcu typu A1 według B. Arrhenius, masowo produkowane już $\mathrm{w}$ starszej fazie istnienia zespołu birczańskiego, można zaszeregować do grupy wyrobów zgrzewanych z żelaza i stali w interesującym nas wariancie.

Materiały z Birki ujawniły jednak również znajomość innych technik zgrzewania żelaza i stali. W grobie nr 187 znaleziono nóż z wkładką stalową w postaci klina umieszczonego między dwoma warstwami żelaza (IV:B:2), a w grobie nr 60A odkryto okaz ze stalową nakładką, tworzącą ostre narzędzia (IV:C:1), zgrzaną z korpusem o strukturze pasmowej, powstałej - jak sądzi B. Arrhenius (1989, s. 84) - przez połączenie na gorąco wielu warstw metalu o różnej strukturze. Ten ostatni to nóż o rzadkiej formie, którego miejscowe pochodzenie podawane jest w wątp- 
liwość (por. na ten temat Arrhenius 1988, s. 102). Obydwa okazy chronologicznie wiążą się z młodszą, a w jednym przypadku nawet ze schyłkową fazą funkcjonowania Birki (na temat datowania grobów patrz Callmer 1977; Selling 1955, tab. 1). Wskazywałoby to na stosunkowo późne pojawienie się tu noży wykonanych w technice typu IV:B:2 i IV:C:1. Można zatem sądzić, że w IX i w 1. połowie $\mathrm{X}$ w. w warsztacie miejscowych kowali niepodzielnie obowiązywał standard trójwarstwowego zgrzewania typu sandwich. Ta jednolitość sposobu produkcji noży wiele mówi o profesjonalizmie tamtejszych wytwórców.

Wydaje się, że nie było to zjawisko o lokalnym jedynie zasięgu. Noże wykonane w technice trójwarstwowego pakietu znane są również z innych stanowisk archeologicznych datowanych na okres wikiński. Jeden egzemplarz odkryto w Hagestad na terenie Skanii (Thomson 1968, s. 136, 138), dalszy pochodzi z Haithabu. Materiały $\mathrm{z}$ tego ostatniego ośrodka omówimy szczegółowiej w dalszej części pracy.

W środowisku skandynawskim technika typu sandwich była niezmiernie żywotna. Tezę tę dobrze ilustrują materiały pozyskane na grodzisku w Eketorp na Olandii. Jest to jeden $\mathrm{z}$ najbardziej interesujących obiektów obronnych na terenie Szwecji (Stenberger 1974, s. 7 i n.; Borg 1976, s. 203 i n.; Eketorp 1976). Na miejscu grodu z okresu wpływów rzymskich (Eketorp I) i warowni zamieszkanej w V-VII, być może do początku VIII w. (Eketorp II), w końcu X stulecia wzniesiono rozległy ośrodek obronny w założeniu kolistym i zwartej, radialnie rozmieszczonej zabudowie z pustym wewnętrznym placem (Eketorp III). Działały tam warsztaty kowalskie usytuowane na obszarze międzywala. Przypuszcza się, że obiekt ten istniał do około 1300 roku. Jego funkcja nie rysuje się do końca jasno. W domostwach odkrytych w obrębie obwałowań brak palenisk, liczny inwentarz wskazuje jednak na permanentne zasiedlenie grodu. Najbardziej przekonująca jest sugestia E. Nyléna (1982, s. 205), który mimo różnic w sposobie zabudowy dopatruje się funkcjonalnych podobieństw między Eketorp III a grodami typu Trelleborg, uznawanymi za ośrodki związane ze strukturami władzy wczesnopaństwowej. Liczne militaria odkryte w Eketorp potwierdzałyby słuszność tej hipotezy. Nie stałby z nią w sprzeczności fakt występowania monet, odważników i innych przedmiotów związanych z zajęciami kupieckimi, znajdowanych w zabudowaniach grodu. Mało prawdopodobna jest $\mathrm{w}$ każdym razie sugestia o funkcji obiektu jako ośrodka wczesnomiejskiego typu Birki czy Haithabu. Z Eketorp III znane są również liczne ślady związków Olandii ze słowiańskimi wybrzeżami Bałtyku.

Ogół noży poddanych badaniom metaloznawczym pochodzi z zespołów związanych wyłącznie z najmłodszą fazą zasiedlenia grodu (Eketorp III). Jest to seria obejmująca 25 okazów, przy czym więcej o technologii wykonania wiemy jedynie na temat 23 egzemplarzy (Arrhenius 1988, s. 97 i n.). Wśród tych ostatnich spotyka się wyłącznie noże zgrzewane, najczęściej z żelaza i stali, czasami jednak również z kilku kawałków stali o podobnej zawartości węgla. Spora ich część to okazy wykonane $\mathrm{w}$ technice sandwich (IV:A:2), tak powszechnie stosowanej w Birce w IX-X w. W Eketorp noże tego typu reprezentowane są jednak zaledwie 
przez blisko 35\% okazów (dla całego zbioru odsetek ten jest jeszcze niższy i wynosi $32 \%$. W długiej serii odnotowano natomiast egzemplarze typu IV:B ze stalowymi wkładkami umieszczonymi między dwoma warstwami żelaza (odpowiednio $30,5 \%$ i $28 \%$ ), jest ich zatem zdecydowanie więcej aniżeli w kolekcji birczańskiej, skąd znany jest zaledwie jeden przykład tego rodzaju. W Eketorp licznie wystąpiły ponadto noże ze stalowym ostrzem w postaci nakładki zgrzewanej z żelaznym, czasami jednak również ze stalowym korpusem (odpowiednio 36\% i 34,8\%) dla serii skróconej do 23 i wydłużonej do 25 egzemplarzy). Spotyka się wśród nich noże o dwuwarstwowym grzbiecie (IV:D:2) lub też o głowni ze stalową otuliną (IV:D:1). Są to rozwiązania, zwłaszcza to drugie, dość rzadko stosowane we wczesnośredniowiecznym kowalstwie europejskim ${ }^{5}$. W tej grupie noży wyraźnie dominują jednak okazy wykonane w technice typu IV:C:1, które wraz z egzemplarzami o klinowatych wkładkach stalowych typu IV:B stanowią najliczniejszy składnik analizowanej kolekcji. Można zatem sądzić, że w XI-XIII w. te dwa standardy technologiczne, oszczędniejsze w zużyciu stali, częściowo również prostsze w wykonaniu, z wolna wypierały tak masowo stosowaną dotąd technikę typu sandwich. Ze względu na słabe rozwarstwienie chronologiczne badanej serii trudno dokładniej ustalić datę zaniku tej techniki zgrzewania, na pewno jednak była ona jeszcze w użyciu co najmniej do końca XI stulecia. Zmiany w technologii produkcji noży szłyby zatem w kierunku uproszczenia zabiegów wytwórczych i racjonalizacji gospodarki surowcowej. Dość podobnie na tę sprawę zapatruje się B. Arrhenius (1988, s. 100), przywołując jako analogię podobnego procesu materiały z ruskiego Nowogrodu Wielkiego, gdzie jednak - jak zobaczymy poniżej - technikę trójwarstwowego pakietu stosowano aż do schyłku XII stulecia.

Zgoła inne wyniki przyniosły badania metaloznawcze noży z Haithabu (Pleiner 1983, s. 63 i n.), założonego u nasady Półwyspu Jutlandzkiego w strefie kontaktowej sasko-duńsko-słowiańskiej (Jankuhn 1971, s. 6 i n.; 1986; patrz też Schietzel 1981; Clarke, Ambrosiani 1991, s. 56 i n., a ze strony nauki polskiej Leciejewicz 1979, s. 120 i n.). Początki tego ważnego nadbałtyckiego ośrodka rzemiosła i wymiany dalekosiężnej sięgają 2. połowy VIII w., najbardziej aktywny był on jednak w IX-X i w 1. połowie XI w., począwszy od osadzenia tu przez duńskiego władcę Gotfreda kupców z obodrzyckiego Reriku (na temat datowania początków Haithabu na podstawie badań dendrochronologicznych patrz Eckstein, Schietzel 1977, s. 141 i n.) $)^{6}$. Podstawowy trzon mieszkańców tego polietnicznego centrum tworzyli Sasi i Danowie, przebywali tu jednak również Słowianie i przybysze z innych krajów, zwłaszcza Fryzowie i Szwedzi (na temat etnicznej atrybucji pochowanych

5 Nóż z ostrzem w postaci nakładki stalowej, o głowni osłoniętej stalową otuliną typu IV:D:1:a, odkryto w Międzyrzeczu Wielkopolskim (badania prof. dr. hab. Z. Głowackiego). Pochodzi on z warstwy datowanej na połowę XII w. Ten sposób formowania głowni ma jednak odległą tradycję sięgającą starożytności (por. Emmerling 1972, s. 283).

${ }^{6}$ Wydaje się, że sporny dotąd problem lokalizacji Reriku został ostatnio rozstrzygnięty dzięki badaniom przeprowadzonym w Gross Strömkendorf; patrz Wietrzichowski 1993, s. 43 i n. 
na cmentarzyskach w Haithabu patrz Steuer 1984, s. 189 i n.; problem obecności Fryzów omawia Ellmers 1985, s. 37). Zmienne też były losy polityczne tego ośrodka. Do końca IX w. znajdował się on we władaniu Danów, później przeszedł w ręce Szwedów, a od 934 r. znalazł się pod kuratelą niemiecką, by wreszcie w latach 80. X w. powrócić do Danii. Założony w miejscu dogodnej przewłoki między rzekami Schlei i Treene stał się najważniejszym punktem wymiany na szlaku handlowym prowadzącym z Europy Zachodniej do krajów nadbałtyckich, zwłaszcza zaś do środkowej Szwecji. Rozległe kontakty handlowe mieszkańców Hedeby poświadcza bogaty i zróżnicowany inwentarz zabytkowy, znaleziony w różnych rejonach tego zespołu osadniczego, którego centrum po opuszczeniu w 2. połowie IX w. tzw. osady południowej (Steuer 1974) znajdowało się na terenie otoczonym w 2. połowie lub końcu X w. potężnym wałem podkowiastym, obejmującym obszar o powierzchni 24 ha. Przy tej głównej osadzie znajdował się port osłonięty palisadą.

Hedeby było również znacznym ośrodkiem działalności wytwórczej, w trakcie badań wykopaliskowych odkryto liczne ślady pracowni rzemieślniczych. Jedną z ważniejszych dziedzin produkcji było kowalstwo i hutnictwo. Na terenie osady południowej żużle skupiają się w jej peryferyjnej części (Steuer 1974, s. 17), natomiast w obrębie obwałowań największą ich koncentrację stwierdzono w zachodniej części osiedla (Müller-Wille 1980, s. 131, tamże dalsza literatura). Obok metalu pozyskiwanego na miejscu, docierał tu również surowiec $z$ innych krajów, zwłaszcza zaś metal niskofosforowy (Herrmann 1982, [tekst nieczytelny]) ${ }^{7}$. Ogół przebadanych dotąd grzywien żelaznych charakteryzuje stosunkowo niska zawartość tej domieszki (Thomsen 1971, s. 16 i n.; Piaskowski 1983a, tabl. 1). Wymienić tu można dwa najbardziej prawdopodobne obszary, a mianowicie Nadrenię i Szwecję, skąd mógł napływać do Haithabu surowiec tej klasy (na temat rozmieszczenia rud niskofosforanowych w Europie patrz Björkenstam, Magnusson 1989, s. 86 i n., ryc. 2). Za szwedzką proweniencją (o rudach niskofosforowych w Szwecji patrz Arrhenius 1959, s. 1 i n.; Clarke [red.] 1979, s. 52 i n.) przemawia między innymi fakt występowania wśród gotowych wyrobów przedmiotów o podwyższonej zawartości niklu (patrz uwagi poniżej), występującego w rudach pochodzenia północnoszwedzkiego, o czym pisałem już, prezentując materiały z Helgö. Wątpliwa wydaje się też sugestia J. Piaskowskiego (1983b, s. 161), jakoby metal o obniżonej zawartości fosforu (poniżej 0,08\% P) pozyskiwano z miejscowych rud darniowych o nieco niższej niż gdzie indziej ilości tej domieszki ${ }^{8}$.

\footnotetext{
7 W krajach strefy nadbałtyckiej nie było to zjawisko rzadkie. Podobnie było na słowiańskich wybrzeżach Bałtyku; por. Herrmann 1988, s. 735-736. Kwestię tę dobrze ilustrują również wyniki przeprowadzonych ostatnio badań metaloznawczych zabytków żelaznych ze Szczecina (badania dr. Z. Hensla). Od Redakcji: związek przypisu z miejscem wskazanym w tekście jest hipotetyczny. Umiejscowienie przypisu zostało dokonane na podstawie jego treści.

8 J. Piaskowski wskazuje ponadto na nierównomierny rozkład fosforu w czasie pozyskiwania w procesie dymarkowym metalu nierównomiernie nawęglonego. Powstaje jednak pytanie, czy prze-
} 
Obok importu surowca docierali tu najpewniej również obcy rzemieślnicy wędrowni, ta bowiem grupa zawodowa odgrywała istotną rolę w dziejach dalekosiężnej wymiany.

W świetle powyższych uwag tym bardziej interesujące są wyniki badań metaloznawczych noży z Haithabu9. Rysujący się na ich podstawie obraz technologii kowalstwa znacznie odbiega od rozpoznanego na przykładzie omówionych powyżej materiałów z terenu Szwecji. Zaskakuje przede wszystkim niski odsetek noży zgrzewanych z żelaza i stali, które w kolekcji liczącej osiem egzemplarzy stanowią zaledwie $37,5 \%$. W chronologicznie zbliżonej serii birczańskiej prawie ogół noży zaliczał się do tej grupy. W Haithabu przeważają natomiast okazy wykonane w prosty i nieskomplikowany sposób. Aż cztery noże wykuto z żelaza kowalnego (Pleiner 1983, noże nr 1-3, 6), z których jeden, być może dwa poddano zabiegowi wtórnego nawęglenia (noże nr 17,3), jeden zaś to okaz o strukturze stali (nóż $\mathrm{nr}$ 4). Wszystkie noże tej grupy były niewątpliwie dziełem kowala o niskich kwalifikacjach (Pleiner 1983, s. 84 i n.).

W tym kontekście na uwagę zasługują wyniki badań składu chemicznego metalu. W dwóch przypadkach było to żelazo niskofosforowe (noże $\mathrm{nr} 1,4$ ), w trzech dalszych - metale o wyraźnie podwyższonej zawartości niklu (noże nr 1-3). Nie był to na pewno surowiec miejscowego pochodzenia. Zwiększony udział niklu mógłby wskazywać na jego szwedzką proweniencję. Jedynie jeden nóż tej serii (nr 6), datowany na $\mathrm{X}$ w., wykonano $\mathrm{z}$ metalu o śladowej zawartości niklu i miedzi, uzyskanego w czasie wytopu wysokofosforowych rud darniowych. W Haithabu należy zatem liczyć się z masowym importem żelaza, zaspokajającego w znacznym stopniu potrzeby surowcowe miejscowych wytwórców. Analizy metaloznawcze noży potwierdzałyby zatem wyniki badań grzywien żelaznych. Ze względu na raczej niskie umiejętności miejscowych kowali można sądzić, że wywodzili się oni ze środowiska wiejskiego, zapewne duńskiego i saskiego. Być może zostali tu oni osadzeni przez czynnik władzy wczesnopaństwowej, podobnie jak miało to miejsce w przypadku kupców przesiedlonych do Hedeby ze słowiańskiego Reriku. Producenci ci, w części zaopatrywani w surowiec przez księcia, kontynuowaliby tradycje produkcyjne swego warsztatu, wytwarzając wyroby w prostej i nieskomplikowanej technologii i technice. Interesujące, że zdecydowana większość noży omawianej grupy wiąże się ze starszą fazą rozwoju miasta, przypadającą na IX wiek.

W tak liczącym się ośrodku życia gospodarczego, jakim było Haithabu, działali niewątpliwie również $\mathrm{w}$ pełni profesjonalni kowale. $\mathrm{Z}$ tą grupą zawodową łączyć zapewne należy noże zgrzewane z żelaza i stali, chociaż mogły być to również - co najmniej w części importy, lub też, co się wydaje bardziej prawdo-

słanki te tłumaczą w sposób zadowalający niską zawartość fosforu w wielu zabytkach żelaznych odkrytych w Haithabu?

9 Jest to niestety seria wyjątkowo krótka, ograniczona do 8 okazów. J. Piaskowski (1983a, s. 57) liczebność próby potrzebnej dla oceny stanu technologii szacuje co najmniej na 20 egzemplarzy. 
podobne - wyroby obcego, może wędrownego rzemieślnika. Być może dziełem kowala związanego z tradycjami rzemiosła szwedzkiego jest jedyny znaleziony w Haithabu nóż wykonany w technice sandwich. Ze względu na potwierdzoną archeologicznie obecność Szwedów w tym ośrodku sugestia ta wydaje się bardzo prawdopodobna, w każdym razie brak jak dotąd danych, które wskazywałyby na masowy charakter produkcji noży tego typu Haithabu, z czym mamy niewątpliwie do czynienia w Birce.

Inną już genezę ma najpewniej nóż żelazny ze stalową nakładką tworzącą jego ostrze (nóż nr 8), datowany na $\mathrm{X}$ w. W krajach skandynawskich jest to jeden z najstarszych przykładów noży wykonanych w technice typu IV:C:1, i to w postaci w pełni wykształconej, co różni go od okazu z Helgö, zgrzanego z dwóch kawałków stali. Egzemplarz z Haithabu wiązać być może należy ze środowiskiem saskim, które mogło być jednym z pośredników w przenikaniu z Europy Zachodniej do krajów strefy nadbałtyckiej tej niewątpliwej spuścizny techniki kowalstwa prowincjonalnorzymskiego, przejętej bezpośrednio przez Franków w dobie merowińskiej (patrz uwagi i literaturę w przypisie 1). Z terytorium zajętym przez Sasów znane są też noże bojowe o wczesnej metryce zaopatrzone w stalowe nakładki łączone z żelaznym grzbietem [za pomocą - dop. Red.] ząbkowanych wkładek wykonanych z żelaza wysokofosforowego (Horstmann 1989, s. 209 i n.). Ten sposób produkcji reprezentuje jeden z bardziej rozwiniętych wariantów techniki zgrzewania żelaznego korpusu narzędzia ze stalowym ostrzem ${ }^{10}$. Zapewne też dzięki pośrednictwu Hedeby technika typu IV:C:1 pojawiła się już w 2. połowie X stulecia w Birce, z wolna wypierając w środowisku szwedzkim metodę typu sandwich, co tak dobrze ilustrują materiały z Eketorp.

Na tym zakończylibyśmy przegląd dostępnych obecnie wyników badań metaloznawczych noży z obszaru rozsiedlenia Skandynawów. Najwięcej informacji pochodzi z terenu Szwecji, zwłaszcza środkowej, zaliczającej się do rejonów o szczególnym znaczeniu w dziejach gospodarczych Normanów. W świetle danych pozyskanych na wyspie Helgö można sądzić, że u schyłku starożytności i w okresie Vendel stosowano rozmaite sposoby produkcji noży. Ta wielość schematów technologicznych była cechą charakterystyczną tej fazy rozwoju kowalstwa skandynawskiego. Produkowano również noże zgrzewane z żelaza i stali, wówczas też pojawiła się technika typu sandwich, chociaż nie zawsze stosowana z pełnym powodzeniem. Dokładne ustalenie daty jej początków w środowisku skandynawskim nie jest niestety możliwe; może opanowano ją już w okresie wędrówek ludów,

10 Technika zgrzewania polegająca na wykorzystaniu ząbkowanych wkładek z żelaza wysokofosforowego znalazła szerokie zastosowanie w krajach strefy nadbałtyckiej w produkcji grotów oszczepów. Szczegóły tego rozwiązania, często towarzyszące dziwerowaniu, są dobrze rozpoznane głównie dzięki badaniom metaloznawczym przeprowadzonym na szeroką skalę w krajach rozsiedlenia plemion bałtyjskich (Antejn 1973, s. 64 i n.; z nowszych opracowań patrz Kulakov, Tolmačeva 1987, s. 94 i n.). Technikę tę stosowano także w produkcji noży, co dobrze ilustrują wyniki badań materiałów z ziem wczesnośredniowiecznej Polski (Gdańsk, Międzyrzecz Wlkp., Młodzikowo pod Środą, Gniezno, Biskupin, Czersk, Łęczyca, Lutomiersk, Opole, Wrocław, Niemcza Śląska). 
najpewniej jednak dopiero $\mathrm{w}$ okresie Vendel w wyniku ożywionych kontaktów gospodarczych i kulturowych z Europą Zachodnią, zwłaszcza zaś z kręgiem merowińskim. W okresie wikińskim, i to już w jego początkach, ten sposób produkcji noży rozpowszechnił się na skalę nigdzie dotąd nieobserwowaną w Europie. Ukonstytuowanie się techniki typu IV:A:2 jako masowo stosowanego standardu było zatem zasługą żywiołu normańskiego. Tak było w każdym razie w ośrodkach liczących się w życiu gospodarczym Skandynawii, między innymi w Birce. Tam przez blisko dwa stulecia była to w praktyce jedyna metoda produkcji noży, typowa dla w pełni profesjonalnego kowala. W Szwecji stosowano ją co najmniej do końca XI w. U schyłku okresu wikińskiego współwystępowała ona z innymi, prostszymi i bardziej ekonomicznymi wariantami techniki zgrzewania żelaza i stali, które pojawiły się już w 2 . połowie X stulecia, najpewniej również $\mathrm{w}$ wyniku oddziaływań zachodnich.

Przedstawiony powyżej zarys dziejów kowalstwa skandynawskiego dotyczy przede wszystkim Szwecji, zwłaszcza środkowej. Ze względu na brak badań metaloznawczych noży nie wiemy niestety, jak proces ten przebiegał na terenie Norwegii i Danii, może jednak i tam w IX-XI w. dominowała technika typu sandwich (por. tu wyniki badań noży z Hagestad w Skanii, która wchodziła w obręb władztwa Duńczyków). Niektóre przesłanki pośrednie, które przedstawimy poniżej, pozwalają liczyć się z tym co najmniej na terytorium Norwegii. Poza tą strefą pozostawało natomiast Haithabu, leżące na pograniczu duńsko-niemiecko-słowiańskim. Znaleziony tam jeden nóż żelazny $\mathrm{z}$ centralnie umieszczoną wkładką stalową wiązać być może należy ze środowiskiem szwedzkim, na co wskazywałem już uprzednio.

Jak stwierdziłem na wstępie niniejszych uwag, technika typu sandwich była znana, a miejscami równie powszechnie stosowana także w innych krajach ówczesnej Europy. Powstaje zatem pytanie, czy doszło do tego w wyniku niezależnego rozwoju, czy też fakt ten należy raczej wiązać z działalnością Skandynawów w obcym im środowisku etnicznym i kulturowym. Podjęcie próby wyjaśnienia tej tak istotnej sprawy zmusza do sięgnięcia po materiały pochodzące z tych krajów, które znalazły się w strefie szczególnych zainteresowań skandynawskich wikingów, którzy tworzyli nie tylko zbrojne oddziały, w ich skład wchodziły bowiem również grupy kupców i rzemieślników. Te zbiorowości mogły być nosicielami rozmaitych doświadczeń zawodowych osiągniętych zarówno na polu wymiany, jak i w zakresie wytwórczości.

$\mathrm{Na}$ wstępie skupię swą uwagę na terytorium Anglii, gdzie już u schyłku VIII w. dotarły wyprawy Normanów (z bogatej literatury przedmiotu patrz ostatnio Wikinger 1992, s. 96 i n., a ze strony nauki polskiej Lipoński 1995, s. 196 i n.). Po pierwszych zbrojnych najazdach, nasilających się począwszy od lat 30. IX w., Skandynawowie bardzo wcześnie podjęli akcję osiedleńczą, w której partycypowali zarówno Duńczycy, jak i Norwegowie. Wkrótce opanowali oni znaczną część Anglii, na trwalej sadowiąc się w Northumbrii, Mercji i wschodniej Anglii, rządzonych odtąd według zasad prawa duńskiego (Danelaw). Ważnym centrum władz- 
twa Normanów był York. Przeważał w nim żywioł norweski. Ośrodek ten budzi szczególne nasze zainteresowanie, stąd pochodzi bowiem najliczniejsza jak dotąd z terytorium Anglii seria noży poddanych badaniom metaloznawczym.

Początki Yorku sięgają doby rzymskiej (Eboracum), później znajdował się tam ważny ośrodek anglosaskiego królestwa Northumbrii (Eoforwic). Przez Skandynawów został on opanowany w 867 r. i wkrótce stał się stolicą królestwa Jorviku, założonego przez Halfdana. Rządy normańskie trwały do 954 r., kiedy to tronu został pozbawiony ostatni z władców Yorku, norweski Eryk Krwawy Topór, a Northumbria powróciła na stałe we władanie Anglii. Wpływy Skandynawów były tu jednak nadal niezmiernie silne, wielu z nich pozostało w Yorku, aktywnie uczestnicząc w życiu gospodarczym miasta (Clarke, Ambrosiani 1991, s. 33, 92 i n.).

$\mathrm{Na}$ temat jego dziejów w okresie władztwa Normanów najwięcej informacji dostarczyły badania archeologiczne przeprowadzone w rejonie ulicy Coppergate (Clarke, Ambrosiani 1991, s. 93 i n.; Wikinger 1992, s. 101) ${ }^{11}$. Odsłonięto tam kilka działek osiedleńczych z domostwami usytuowanymi ścianami szczytowymi wzdłuż ciągów ulicznych. Pierwsze dekady pobytu Normanów znajdują dość słabe oświetlenie w materiale zabytkowym. Sytuacja zmieniła się dopiero na początku X stulecia. Odtąd York rysuje się jako ważny ośrodek wytwórczości rzemieślniczej i dalekosiężnej wymiany handlowej przybyszów ze Skandynawii. Wśród wielu uprawianych tam rzemiosł liczącą się pozycję zajmowała obróbka żelaza. Z wykopu przy ulicy Coppergate pochodzą też noże żelazne poddane badaniom metaloznawczym (McDonnell 1989, s. 373 i n.). Jest to relatywnie długa seria obejmująca 50 okazów, z których 45 wiąże się z fazami osadniczymi datowanymi od około połowy IX do 2. połowy XI w. (na temat datowania faz patrz Hall 1990, s. 375 i n.). Z nawarstwień fazy 3, przypadającej na 2. połowę IX do schyłku tego stulecia lub początków X w., badaniami metaloznawczymi objęto 8 noży, wśród których - obok dwóch egzemplarzy wykutych ze stali - odnotowano wyłącznie noże zgrzewane z żelaza i stali. Były to głównie okazy wykonane w technice typu IV:C:1, czyli noże żelazne ze stalowymi nakładkami tworzącymi ostrze narzędzia (62,5\%). Zaledwie jeden nóż reprezentuje szczególnie interesujący nas tu wariant zgrzewania typu sandwich. W zgoła innych proporcjach wystąpiły noże obydwu tych grup w dwóch chronologicznie młodszych fazach osadniczych, z których do badań pobrano dłuższe kolekcje w liczbie 18 i 19 okazów. I tak w poziomie 4, datowanym na schyłek IX lub początek X w., do około 975 r., odsetek noży z centralnie umieszczoną wkładką stalową wynosi 36,8\%, a w poziomie $5 \mathrm{z}$ ostatniej ćwierci X do 2. połowy XI w. ich udział dochodzi już do 70\%. Towarzyszył temu stały spadek frekwencji noży żelaznych ze stalowymi nakładkami od 31\% $\mathrm{w}$ poziomie 4 do zaledwie $17 \% \mathrm{w}$ poziomie 5 .

11 Opracowania materiałów z badań archeologicznych prowadzonych w Yorku publikowane są w serii pt. The Archaeology of York. Na temat źródeł związanych z okresem rządów Skandynawów patrz zwłaszcza tom 8, zeszyty 1-4, tom 16, zeszyt 5 oraz tom 17, zeszyty $3,7$. 
Są to wyniki zaskakujące. Okazało się, że w miarę upływu czasu prostszą i bardziej oszczędną technikę zgrzewania typu IV:C:1 systematycznie wypierała bardziej złożona i pracochłonna metoda produkcji typu sandwich. Zazwyczaj stwierdza się tendencję odwrotną. Tak było między innymi w Szwecji, o czym pisałem już powyżej, a do podobnego wniosku skłaniają również materiały z północnej Rusi, jak zobaczymy to w dalszej części pracy. W Anglii, na terenach znajdujących się we władaniu Normanów, rodzima - anglosaska technika produkcji noży typu IV:C:1, powszechnie stosowana już w dobie poprzedzającej pojawienie się skandynawskich przybyszów, co dobrze ilustrują wyniki badań metaloznawczych noży z Hamwic, czyli z anglosaskiego Southampton (McDonnall 1989, tab. 3; na temat tego ośrodka patrz Clarke, Ambrosiani 1991, s. 22-23, $35)^{12}$, ustąpiła miejsca nawykom produkcyjnym przyniesionym przez kowali normańskich osiadłych w Yorku. Nie przyjęli oni miejscowej techniki produkcji, wytwarzając noże zgodnie ze standardem obowiązującym w ich macierzystych warsztatach. W miarę stabilizacji $\mathrm{w}$ mieście żywiołu skandynawskiego te obce nawyki produkcyjne zyskiwały na znaczeniu, a tendencja ta utrzymała się również i później, po utracie niezależności politycznej Yorku. Tradycja ta kontynuowana była jeszcze w XII stuleciu, a zatem w okresie, w którym w Skandynawii dawno już w produkcji noży upowszechnił się, najpewniej pod wpływem impulsów docierających z Europy Zachodniej, prostszy i bardziej ekonomiczny wariant zgrzewania żelaza i stali typu IV:C:1. Jest to stwierdzenie niezmiernie ważne, można bowiem sądzić, że kowale skandynawscy działający na terenach macierzystych byli bardziej podatni na wpływy zewnętrzne niż grupy wytwórców osiadłych na obszarach obcych etnicznie. W nowym środowisku byli oni bardziej przywiązani do własnych doświadczeń produkcyjnych.

W zasiedlaniu Anglii uczestniczyli zarówno Duńczycy, jak i Norwegowie. W Yorku, o czym mówiłam już powyżej, przeważali ci ostatni. Jak dotąd brak jednak danych na temat stosowanych przez nich metod produkcji noży w ich rodzimych ośrodkach wytwórczości rzemieślniczych. Wyniki badań pozyskane z Yorku pozwalają jednak sądzić, że w Norwegii, a zatem podobnie jak na terenie Szwecji, w okresie wikińskim dominowała technika typu sandwich. Ta pośrednia droga wnioskowania wzbogaca zatem skromny dotąd zasób wiedzy na temat poziomu skandynawskiego kowalstwa. Na tym też polega między innymi wartość poznawcza rezultatów badań metaloznawczych noży odkrytych w Yorku.

Równie aktywna była działalność skandynawskich wikingów na wschodnim szlaku ich wędrówki. Na obszar Rusi pierwsze grupy Normanów dotarły w rejon ujścia Wołchowa już w 2. połowie VIII w. (Kirpičnikov, Dubov, Lebedev 1986, s. 189 i n.). Byli to zarówno kupcy, jak i współdziałający z nimi wędrowni rze-

\footnotetext{
${ }_{12}$ W Hamwic jeden z 14 badanych noży wykonano być może w technice sandwich (McDonnell 1989, tab. 3). Pamiętać jednak należy, że okolice tego anglosaskiego ośrodka miejskiego bardzo wcześnie były nawiedzane przez Normanów, którzy już w latach 60 . IX w. podjęli tam próbę stałego osiedlenia się (Lipoński 1995, s. 307, 309).
} 
mieślnicy, których obecność potwierdza odkrycie w najstarszych nawarstwieniach kulturowych Starej Ładogi warsztatu profesjonalnego kowala wywodzącego się najpewniej ze środowiska skandynawskiego (Rjabinin 1980, s. 161 i n.; 1985, s. 64). Stąd Normanowie przenikali na południe szlakiem wołchowsko-dnieprzańskim i na południowy wschód różnymi odnogami szlaku wołżańskiego. Na tym ostatnim kierunku już w IX w. znaleźli się oni w okolicach Jarosławla i Rostowa (Dubov 1982, s. 46 i n.; 1989, s. 180 i n.), a na szlaku południowym równie wcześnie osiągnęli basen jeziora Ilmen (Nosov 1990) oraz Smoleńszczyznę (Alekseev 1980, s. 81 i n.). Docierali oni także w rejon Jeziora Pskowskiego oraz na obszar południowo-wschodniego zlewiska jeziora Ładoga (por. ostatnio Boguslavskij 1993, s. 132 i n.). Działalność Skandynawów związana była głównie z osiedlami wczesnomiejskimi w Starej Ładodze (Sedov [red.] 1985), Rjurikowie (Nosov 1990), Gniozdowie (patrz ostatnio Avdusin [red.] 1991; por. też Łosiński 1992, s. 139 i n.) ${ }^{13}$, Pskowie (Beleckij 1993, s. 78 i n.; na temat elementów skandynawskich patrz Sedov 1992, s. 143 i n.), Izborsku (Sedov 1985, s. 119 i n.; Gajdukov, Fomin 1986, s. 101 i n.), Timierowie (Dubov 1982, s. 124 i n.; 1988, s. 136 i n.; 1989, s. 103 i n.), Sarskim gorodišču (Leont'ev 1974, s. 68 i n.; 1981, s. 175 i n.). Wszędzie tam jest poświadczona archeologicznie ich obecność.

Skandynawowie przenikali również na terytorium środkowego Naddnieprza, i to najpewniej już w latach 830. [w 30. latach IX w. - dop. Red.], jak wynikałoby $\mathrm{z}$ danych zamieszczonych $\mathrm{w}$ Rocznikach Bertyniańskich (na temat opisanych tam wydarzeń patrz Sacharov 1980, s. 36-46). Z tego obszaru znana jest jednak skromna liczba zespołów znalezisk o cechach kultury normańskiej. Ograniczają się one w zasadzie do Kijowa i okolic Czernihowa (por. ostatnio Mocja 1990, s. 90 i n.). Kontrastuje to z obrazem uzyskanym na ziemiach północnej Rusi. Linię demarkacyjną wyznacza przebieg południowej granicy późniejszych ziem: rostowo-suzdalskiej, smoleńskiej i częściowo połockiej. Jedynie obszary położone na północ od tej linii przesycone są inwentarzem zabytkowym typowym dla skandynawskiego kręgu kulturowego. Tam też aktywność żywiołu normańskiego była niewątpliwie najbardziej intensywna.

To rozległe terytorium zasiedlone było pierwotnie przez plemiona bałtyjskie i fińskie (Sedov 1987), na które nawarstwiły się fale osadników słowiańskich. Najwcześniej zasiedlili oni dorzecze górnego Dniepru, zlewiska Jezior Pskowskiego i Ilmeńskiego oraz dolinę rzeki Wołchow, gdzie ukształtowały się ugrupowania plemienne Krywiczów i Słowenów (Sedov 1982). Później Słowianie przemieszcza-

${ }^{13} \mathrm{~W}$ polskiej i północno-zachodnioeuropejskiej literaturze przedmiotu powszechnie używa się nazwy „Gniezdowo”. Odstępuję od tej formy, bowiem nazwa tej miejscowości w języku rosyjskim brzmi „Гнёздово”, а nie „Гнездово” (por. Avdusin [red.] 1991; Puškina, Rozanova 1992, s. 200). Zgodnie z zasadami transkrypcji (patrz Słownik ortograficzny języka polskiego, Warszawa 1977, s. 140 i n.) powinno się zatem pisać „Gniozdowo”, a nie „Gniezdovo”. Tę wykładnię zaproponowałem już dawniej (Łosiński 1992, s. 139). Można jednak w zgodzie z normami transliteracji pisać również „Gnëzdovo". Moja propozycja nie znalazła, jak dotąd, uznania, wręcz budzi opór. Okazuje się, że przywiązanie do tradycyjnej formy jest niezmiernie silne i ciągle znajduje niezłomnych obrońców. 
li się wzdłuż szlaku wołżańskiego na ziemie fińskiej Merii i Wesi (Dubov 1989, s. $194 \mathrm{i} \mathrm{n.).}$

Nie do końca jasno przedstawia się niestety sprawa chronologii tych kolejnych fal osadnictwa słowiańskiego. Do niedawna panował pogląd o stosunkowo wczesnej metryce zasiedlenia przez Słowian północnej Rusi. Dziś takie widzenie tej kwestii podaje się niekiedy $\mathrm{w}$ wątpliwość i sądzi się, że Słowianie dotarli tam najwcześniej w IX a w zasadzie dopiero w X w., kiedy to kolonizacja słowiańska miała przybrać formę bardziej zorganizowaną (Artamonov 1990, s. 271 i n.; Okulicz-Kozaryn 1993, s. 45, 116, 223). Do tego czasu o obliczu etnokulturowym tego obszaru miał decydować żywioł fiński, miejscami zaś bałtyjski. Przy przyjęciu tej wykładni pojawienie się na tych terenach przybyszów ze Skandynawii, zapoczątkowane ich osadzeniem się w 2. połowie VIII w. w Starej Ładodze, nie byłoby jednoznaczne z nawiązaniem przez nich kontaktów ze Słowianami, ale raczej z pierwszymi mieszkańcami tych ziem. Sprawa jest niewątpliwie dyskusyjna, niezmiernie jednak ważna również przy próbie oceny wyników badań metaloznawczych, stąd też sygnalizujemy te dwa wzajemnie opozycyjne punkty widzenia na temat kolonizacji słowiańskiej na obszarze północnej Rusi.

Skala badań metaloznawczych prowadzonych na terenie Rosji, a także na Ukrainie i Białorusi, nie ma w praktyce, może poza ziemiami Polski, swego europejskiego odpowiednika. Zostały one zapoczątkowane przez B.A. Kolčina (1953), autora monumentalnej monografii poświęconej dziejom hutnictwa i kowalstwa na terytorium Rusi Kijowskiej. Studium to opierało się na wynikach badań metaloznawczych 286 przedmiotów żelaznych, wśród których najliczniejszą serię tworzyły noże w liczbie 63 okazów pochodzących z 19 stanowisk archeologicznych. Dziś lista zabytków o rozpoznanej technologii wykonania obejmuje tysiące wyrobów. Są to nadal głównie noże, stanowiące imponującą kolekcję składającą się z ponad 1600 egzemplarzy, z których zdecydowana większość (1464 okazy) pochodzi $\mathrm{z}$ obszaru mieszczącego się w granicach Rusi Kijowskiej, pozostałe zaś znaleziono na terenach ościennych, znajdujących się we władaniu Chazarów, Bułgarów nadwołżańskich i plemion Finów nadkamskich (171 egzemplarzy) ${ }^{14}$.

W zbiorze noży zebranych ze stanowisk ruskich odsetek okazów zgrzewanych z żelaza i stali wynosi $55 \%$. Przeważają noże z ostrzem w postaci stalowych nakładek zgrzanych z żelaznym korpusem narzędzia. Ich odsetek dochodzi do $32 \%$. Drugie miejsce zajmują szczególnie interesujące nas tu noże wykonane w technice sandwich; stanowią one ponad 17\% ogółu badanych noży. Wcześnie okazało się, że nie są one równomiernie rozmieszczone na terenie Rusi. Najczęściej spotyka się je w kolekcjach pochodzących z północnych połaci ziem ruskich, gdzie już

\footnotetext{
${ }^{14}$ Seria noży objętych badaniami metaloznawczymi jest niewątpliwie dłuższa. Niektóre publikacje zapewne pominąłem, do innych zaś nie udało mi się dotrzeć, mimo pomocy badaczy rosyjskich, w tym dr. E. Nosova i dr. V. Kulakova, którym w tym zakresie wiele zawdzięczam. Z uwzględnienia niektórych prac świadomie jednak zrezygnowałem, jeżeli tylko istniały problemy z ustaleniem chronologii badanych kolekcji (por. np. Pobol', Gurin 1979, s. 96 i n.; 1980, s. 341 i n.).
} 
w zbiorach datowanych na starsze fazy wczesnego średniowiecza stanowią liczący się składnik zespołów. Zwróciło na to uwagę wielu badaczy (Voznesenskaja, Kovalenko 1985, s. 106 i n.; Kočkurkina, Rozanova 1987, s. 90; Zav'jalov 1989a, s. 20 i n.; Rozanova 1991, s. 220; Puškina, Rozanova 1992, s. 205-206, 218), podważając tym samym jedną z tez B.A. Kolčina, który sądził, że ten typ zgrzewania żelaza i stali był powszechnie stosowany w warsztacie profesjonalnego rzemieślnika na terenie całej Rusi.

Przegląd dostępnych obecnie materiałów w pełni potwierdza sugestię cytowanych powyżej badaczy. W kolekcji pochodzącej z południowej Rusi, liczącej ponad 500 noży, zaledwie niecałe 5\% okazów wykonano w technice trójwarstwowego pakietu. Poza Kijowem (Novoe v archeologii 1981, s. 279 i n.), gdzie wystąpiły one w nieco wyższym odsetku około 18\% (Kočkurkina, Rozanowa 1987, s. 91), są tam reprezentowane zaledwie przez pojedyncze egzemplarze. Tę niską ich frekwencję potwierdziły wyniki badań metaloznawczych noży z Ljubeča (Voznesenskaja 1965c, s. 145 i n.), Belgorodu (Mezencova, Gopak 1974, s. 74 i n.), [tekst nieczytelny] (Voznesenskaja, Kovalenko 1985, s. 108), Novgrodu Severskego (Voznenskaja, Kovalenko 1985, s. 96-98), Rjabčeva (Voznesenskaja, Kovalenko 1985, s. 105-106), Serenska (Chomutova 1973, s. 216 i n.) i Starej Rjazani (Tolmačeva 1983, s. 245 i n.). Zbiory te w większości przypadków pochodzą z X-XII lub XI-XIII w. Wszędzie tam noże zgrzewne z żelaza i stali to przede wszystkim okazy wykonane w technice typu IV:C:1, których odsetek waha się od kilkunastu do kilkudziesięciu procent, w skrajnych przypadkach dochodząc do 60\% (Slobodka, Orlovskaja obl.; por. Rozanova 1987, s. 152 i n.). Na terenie Rusi południowej okazy wykonane w technice sandwich znane są również ze stanowisk o starszej metryce, datowanych na 2. połowę I tysiąclecia n.e.; tam jednak spotyka się je dość rzadko, i to wyłącznie na obszarze międzyrzecza Dniepru i Dońca. Najstarsze z przełomu VIII i IX w. odkryto na osadzie w Volyncevo (Slavjane 1990, s. 390), chronologicznie nieco młodsze pochodzą z grodzisk kultury romeńsko-borszewskiej w Titčicha (Voznesenskaja 1965b, s. 251 i n.) i Gornal' (Voznesenskaja 1979, s. 70 i n.; Slavjane 1990, s. 392).

Zgoła inny obraz rysuje się w świetle wyników badań metaloznawczych noży ze stanowisk północnoruskich. W zbiorze składającym się z ponad 950 egzemplarzy, datowanych na 2. połowę VIII-XIII w., noży z centralnie umieszczoną wkładką stalową interesującego nas tu typu stanowią około 25\% ogółu dostępnej obecnie serii. W najwyższym odsetku spotyka się je na ziemi nowogrodzkiej (około 35\%), a zwłaszcza smoleńskiej (ponad 60\%) ${ }^{15}$, sporo jest ich również na ziemi rostowo-suzdalskiej (27\%), najmniej zaś na ziemi połockiej, gdzie ich udział dochodzi zaledwie do około 8\%, bardziej zatem odpowiada frekwencji znanej z Rusi połu-

\footnotetext{
15 Ten wysoki odsetek noży wykonanych w technice typu IV:A:2 na terenie ziemi smoleńskiej to najpewniej rezultat bardzo nierównomiernego chronologicznego rozkładu noży objętych badaniami metaloznawczymi. Zdecydowana ich większość pochodzi ze stanowisk datowanych do schyłku X lub początku XI w.
} 
dniowej niż północnej. Wszędzie tam, w tym również na ziemi połockiej, zwraca uwagę gęsta sieć punktów osadniczych i cmentarzysk, w których inwentarzu zabytkowym znajdowane są nierzadko w dość długich seriach noże analizowanej grupy. Odkryto je co najmniej na 56 stanowiskach na ogólną liczbę 76 obiektów, z których pobrano noże do badań metaloznawczych. W świetle tych danych w pełni zasadny wydaje się pogląd tych badaczy, którzy zabieg trójwarstwowego zgrzewania żelaza i stali uznali na tym rozległym terytorium za standard technologiczny powszechnie stosowany $\mathrm{w}$ produkcji noży $\mathrm{w}$ warsztacie profesjonalnego rzemieślnika.

Rozrzut noży wykonanych $\mathrm{w}$ technice sandwich koresponduje z rozmieszczeniem na terenie Rusi zespołów znalezisk o cechach charakterystycznych dla skandynawskiego kręgu kulturowego. Zbieżność w dyspersji obydwu kategorii źródeł jest wręcz uderzająca. Wcześnie na ten aspekt zagadnienia zwrócono też uwagę w rosyjskiej literaturze przedmiotu, dopuszczając możliwość skandynawskiej genezy umiejętności trójwarstwowego zgrzewania żelaza i stali na ziemiach ruskich. I w tej zatem tak istotnej kwestii zajęto stanowisko odmienne od ujęcia przedstawionego przez B.A. Kolčina (1953, s. 207), który wyeliminował Normanów z kręgu ewentualnych nosicieli tej techniki na Rusi. Pierwsza problem ten poruszyła L.S. Chomutova (1984, s. 208), opierając się na wynikach badań metaloznawczych noży ze Starej Ładogi i Gorodišča (Krutik). Później podobny był również tenor wypowiedzi szeregu innych badaczy (Zav'jalov 1989b, s. 171; Rozanova 1991, s. 220-221; Puškina, Rozanova 1992, s. 218), chociaż nadal problem ten uważa się czasami za otwarty (por. np. Gurin 1984, s. 311 i n.). Do podobnego wniosku prowadzą jednak również wyniki analizy formalno-typologicznej noży, wśród których często spotyka się okazy stanowiące ścisłe odpowiedniki form skandynawskich (noże grupy $4 \mathrm{wg}$ R.S. Minasjana). W literaturze przedmiotu zwraca się też uwagę na silne wpływy kręgu normańskiego na północnoruskie rzemiosło kowalskie, czytelne zwłaszcza w zakresie form noży (Minajsan 1980, s. 72 i n.). Przyjrzyjmy się zatem bliżej tej sprawie, sięgając przede wszystkim po serie noży pochodzące z tak ważnych stanowisk archeologicznych, jak Stara Ładoga, Sarskoje gorodišče, Krutik, Nowogród Wielki i z szeregu dalszych obiektów położonych zwłaszcza w basenie jeziora Ilmen i w zlewisku jeziora Ładoga.

Szczególnie istotne są rezultaty badań metaloznawczych noży ze Starej Ładogi (Chomutova 1984, s. 208; 1985, s. 216-217). Stąd pochodzą najstarsze na Rusi północnej okazy wykonane w technice typu sandwich. Odkryto je już w najniższych poziomach osadniczych, datowanych na 2. połowę VIII w. (na temat chronologii początków Starej Ładogi patrz ostatnio Sedov [red.] 1985, s. 72 i n.; Rjabinin, Černych 1988, s. 72 i n.). W warstwach kulturowych z tego czasu odsłonięto też wzmiankowany już powyżej warsztat kowala, wywodzącego się najpewniej ze środowiska skandynawskiego. Interesujące nas tu noże mogą zatem pochodzić z pracowni obcego rzemieślnika, w każdym razie standard typu sandwich był w Starej Ładodze powszechnie stosowaną metodą produkcji noży co 
najmniej do końca X w. i trudno byłoby sądzić, aby były to w większości wyroby sprowadzane w wyniku nawiązanych wówczas kontaktów handlowych ze Skandynawią. Grupę okazów zgrzewanych uzupełnia nóż żelazny z ostrzem stalowym wykonanym w technice typu IV:C:1. Nie jest nam niestety znana jego pozycja stratygraficzna, ze względu jednak na chronologię serii uprawniony jest sąd o stosunkowo wczesnym pojawieniu się na obszarze Rusi północnej noży wykonanych w tej prostszej formie technologii zgrzewania żelaza i stali.

Do wyrobów rzemieślnika dobrze obeznanego z umiejętnościami warsztatu kowala skandynawskiego zaliczyć można również liczne noże pochodzące z cmentarzysk kurhanowych zajmujących południowo-wschodnie zlewisko jeziora Ładoga. Osadnictwo słowiańskie było tam stosunkowo późnej daty, wcześnie natomiast dotarła w ten rejon najstarsza fala przybyszów normańskich (Sedov 1970, s. 19 i n.; 1982, s. 184; 1987, s. 57 i n.; Kirpičnikov, Dubov, Lebedev 1986, s. 197; Kirpičnikov 1988, s. 70 i n.; ostatnio patrz Boguslavskij 1993, s. 132 i n.). Badania metaloznawcze- zarówno mikro-, jak i makroskopowe (Kolčin 1953, s. 220-221; Chomutova 1985, s. 207 i n.; Ravdina 1988, nr 88, 94, 108, 231), ujawniły znaczną grupę noży (około 67\%) wykonanych w technice trójwarstwowego pakietu. W serii datowanej na 2. połowę IX do XI w. ich odsetek wynosi ponad 90\% ogółu przypadków, w tym okresie prawie całe zapotrzebowanie miejscowych wspólnot lokalnych na tak powszechne wyroby kowalstwa, jakimi były noże, pokrywały warsztaty wysoko wyspecjalizowanych rzemieślników. W kolekcji o młodszych współrzędnych chronologicznych, przypadającej na XI-XII w., frekwencja noży tej grupy spada do 33\%. Ich miejsce w tym czasie zajmują okazy z klinowatymi wkładkami typu IV:B oraz nakładkami stalowymi osadzonymi w żelaznym korpusie narzędzia typu IV:C:1.

Trudno rozstrzygnąć, czy znane stamtąd noże wykonane w technice sandwich powstały w miejscowych warsztatach, czy też pochodzą one z pracowni Starej Ładogi, z którą mieszkańcy tego obszaru utrzymywali bardzo bliskie kontakty gospodarcze (por. cyt. powyżej literaturę). Ta druga sugestia wydaje się bardziej prawdopodobna, w południowo-wschodnim zlewisku jeziora Ładoga nie odkryto bowiem jak dotąd bardziej liczącego się ośrodka rzemieślniczo-targowego.

Związek techniki typu sandwich z warsztatem rzemieślnika wywodzącego się ze środowiska skandynawskiego zdają się również potwierdzać wyniki badań metaloznawczych noży z Gniozdowa, ważnego centrum rzemiosła i handlu, w którego dziejach rola żywiołu skandynawskiego rysuje się szczególnie wyraźnie. Ostatnio oblicza się, że co najmniej 1/4 część mieszkańców tego zespołu osadniczego była pochodzenia normańskiego (Avdusin [red.] 1991, s. 215-216). Obok kupców i zbrojnej drużyny przebywali tam niewątpliwie również rzemieślnicy skandynawscy. W Gniozdowie wyjątkowo wysoki jest też udział noży wykonanych w technice typu IV:A:2 (Kolčin 1953, s. 220-221; Astaškova, Puškina, Rozanova 1985, s. 55-56; Puškina, Rozanova 1992, s. 200 i n.; patrz też Ravdina 1988, nr 52, 
gdzie wyniki obserwacji makroskopowej noży), który w kolekcji liczącej 42 egzemplarze wynosi ponad $83 \%$. Chronologicznie seria ta przypada na 2. połowę IX do przełomu X i XI w. W świetle tych danych można liczyć się z pobytem w Gniozdowie kowali skandynawskich, którzy przynieśli ze sobą nawyki i umiejętności produkcyjne powszechnie stosowane w ich macierzystych ośrodkach wytwórczości.

W kolekcji z Gniozdowa, podobnie jak w seriach ze Starej Ładogi oraz z południowo-wschodniego zlewiska jeziora Ładoga, wystąpiły także pojedyncze okazy z klinowatymi wkładkami typu IV:B i z nakładkami stalowymi typu IV:C:1, reprezentujące $\mathrm{w}$ sposobie wykonania uproszczone metody zgrzewania żelaza i stali. $\mathrm{Na}$ Rusi północnej najstarsze noże tego rodzaju można zatem datować najpóźniej na 2. połowę X i początek XI w. Dobrze koresponduje to z przedstawionymi powyżej danymi z terenu Szwecji, gdzie mniej więcej współcześnie pojawiły się podobne rozwiązania techniczne. Do kwestii tej powrócę jednak jeszcze poniżej, bowiem sprawa genezy zwłaszcza techniki typu IV:C:1 na ziemiach Rusi północnej jest bardziej złożona niż można by sądzić na podstawie dotąd zaprezentowanych materiałów.

Powstaje jednak pytanie, czy ogół noży wykonanych w technice trójwarstwowego pakietu, tak licznie reprezentowanych $\mathrm{w}$ północnoruskich kolekcjach datowanych na schyłek I. tysiąclecia n.e., można wiązać wyłącznie z działalnością obcego rzemieślnika pochodzenia normańskiego. Część noży to być może wyroby importowane bezpośrednio za Skandynawii (dalsze uwagi na ten temat patrz poniżej), część zaś z nich mogła pochodzić z warsztatów miejscowych wytwórców, którzy w miarę postępu czasu przyswoili sobie obce w swej genezie nawyki i umiejętności produkcyjne. Duże skupiska ludzkie, do których zaliczały się osiedla wczesnomiejskie, sprzyjały niewątpliwie wymianie idei, w tym i wytwórczych (Campbell 1995, s. 206), chociaż obowiązywała zapewne również zasada zachowania $\mathrm{w}$ tajemnicy stosowanych metod produkcji.

Ten aspekt zagadnienia jest szczególnie interesujący, bowiem w rosyjskiej literaturze przedmiotu technikę typu sandwich uważa się powszechnie za charakterystyczną dla warsztatu słowiańskich kowali Rusi północnej. I na tę sprawę ciekawy snop światła rzuciły wyniki prowadzonych w ostatnich latach badań metaloznawczych. Szczególnie ważne rezultaty przyniosły ekspertyzy noży pochodzących z kilku osad otwartych położonych w rejonie jeziora Ilmen. Są to wszystko stanowiska o stosunkowo wczesnej metryce, datowane głównie na IX w., są zatem mniej więcej współczesne starszym fazom funkcjonowania Starej Ładogi. Przeważa pogląd o słowiańskim pochodzeniu ich mieszkańców (por. ostatnio Nosov 1991/1992, s. 65 i n.), chociaż niekiedy terytorium to w IX w. uważa się za obszar rozsiedlenia plemion fińskich (Okulicz-Kozaryn 1993, s. 45). Z inwentarza tej grupy osad do badań metaloznawczych wybrano 26 noży (Nosov, Rozanova 1989, s. 102 i n.). Brak wśród nich okazów zgrzewanych z żelaza i stali. Były to w większości przypadków noże wykute z żelaza lub niskowęglowej stali dymarkowej, czasami również z surowca o strukturze pasmowej. W grupie 
wyrobów żelaznych spotyka się jednak również egzemplarze zgrzewane z trzech warstw, w sposobie wykonania powielające technikę typu sandwich. Przy ich produkcji nie użyto jednak stali, ale żelaza o podwyższonej zawartości fosforu, powodującego co prawda wzrost kruchości materiału, ale zwiększającego zarazem jego twardość ${ }^{16}$. Jest to wyraźne, choć nieudolne naśladownictwo techniki typu IV:A:2. Widocznie nie rozróżniano jeszcze wówczas wysokowęglowej stali od żelaza o znacznie podwyższonej zawartości fosforu. Interesujące nas tu noże to zapewne wyroby miejscowe, słowiańskich, a może fińskich kowali, którzy zetknęli się z warsztatem obcego rzemieślnika i podjęli próby naśladownictwa obcych im zabiegów technicznych i technologicznych. Była to niewątpliwie droga prowadząca w przyszłości do opanowania przez miejscowego wytwórcę tej skomplikowanej metody produkcji narzędzi.

Nie sądzę jednak, aby doszło do tego zbyt wcześnie już w starszych fazach wczesnego średniowiecza. O tym, że w tym czasie noże wykonane w technice IV:A:2 związane były głównie z warsztatem obcego rzemieślnika, zdają się świadczyć wyniki badań metaloznawczych noży z osady Krutik, założonej u schyłku IX w. nad Szeksną na terenie fińskiej Wesi, zamieszkującej zlewisko Jeziora Białego, oraz z Sarskogo gorodišča, ważnego centrum Merii, od przełomu VIII i IX w. pełniącego zarazem funkcję osiedla rzemieślniczo-handlowego na wołżańskim szla$\mathrm{ku}$ handlu dalekosiężnego.

Sarskoe gorodišče położone jest nad jeziorem Nero, w okolicach późniejszego Rostowa. Na ogół przypuszcza się, że pierwsze grupy Słowian dotarły tam, podobnie jak w rejon Jarosławla, już w IX w. (Dubov 1982, s. 39 i n.; 1988, s. 145 i n.; Kirpičnikov, Dubov, Lebedev 1986, s. 215-216; Leont'ev 1987, s. 154 i n.; Sedov 1987, s. 73 i n.; na temat kolonizacji słowiańskiej środowiska wiejskiego Merii patrz Leont'ev, Rjabnin 1980, s. 67 i n.). Niekiedy jednak podaje się w wątpliwość tezę o wczesnej kolonizacji słowiańskiej tych ziem. Na poparcie tej hipotezy przywołuje się materiały z pobliskiego Timierowa, gdzie pierwsi Słowianie mieli się pojawić dopiero w 2. połowie X stulecia (Nedošivina, Fechner 1985, s. 114; Fechner, Nedošivina 1987, s. 87; Artamonov 1990, s. 284; w literaturze przedmiotu przeważa jednak pogląd o wczesnej dacie pojawienia się Słowian w Timierowie; por. wyżej cytowane prace, zwłaszcza Dubova). Wątpliwości nie ulega natomiast udział Skandynawów w życiu gospodarczym Merii już w IX w. (na temat znalezisk pochodzenia normańskiego w Timierowie patrz Dubov 1977, s. 175 i n., a w Sar-

16 Por. Schürmann 1959, s. 122. Tę drogę eksperymentowania stwierdzono także w badaniach metaloznawczych materiałów z innych krajów; por. np. Bühler, Strassburger 1966, s. 615 i n. Powstaje zatem pytanie, na które trudno dać jednoznaczną odpowiedź, czy zastosowanie w miejsce stali żelaza wysokofosforowego wynikało jedynie z braku umiejętności rozróżniania obydwu tych surowców, czy też był to raczej wynik świadomego działania profesjonalnego wytwórcy (z tym mamy najpewniej do czynienia w przypadku dziwerowanego miecza z ostrzem w postaci nakładek wykonanych z żelaza wysokofosforowego; por. wyżej wymienieni autorzy), który w ten sposób radził sobie w sytuacji niedoboru stali. Mogło do tego dochodzić zwłaszcza w przypadku zbytu produktów na odległe rynki. 
skoe gorodišče por. Leont'ev 1981, s. 141 i n.), stamtąd też są znane wczesne skarby monet arabskich, w skład których wchodzą dirhemy znakowane skandynawskimi runami (Dobrovol'skij, Dubov, Kuz'menko 1981, s. 53 i n.; 1991).

Z Sarskogo gorodišča badaniami metaloznawczymi objęto 20 noży, pochodzących z nawarstwień kulturowych datowanych na VIII do początku XI w. (Leont'ev 1976, s. 33 i n.; patrz też Kolčin 1953, s. 222). Spotyka się wśród nich okazy o różnej genezie i formie. Część z nich to wyroby fińskiego pochodzenia, liczbowo dominujące w zespole. W niewiele krótszej serii wystąpiły jednak również noże o formie typowej dla obszaru Rusi północno-zachodniej, zaliczające się między innymi do grupy IV wg R. S. Minasjana (1980), o rodowodzie skandynawskim. Obydwie grupy noży różni technika i technologia produkcji. Pierwsze z nich to prawie wyłącznie okazy wykute z żelaza kowalnego ze śladami nierównomiernego nawęglania pierwotnego, czasami także noże o cementowanych ostrzach. Wśród drugich spotyka się głównie egzemplarze wykonane w technice typu sandwich. Stanowią one blisko 90\% ogółu tej części zbioru. Jedynie jeden okaz nawiązujący z punktu widzenia formy do wyrobów o rodzimej genezie wykonano w tej manierze, nie jest to jednak wyrób doskonały, mamy tu raczej do czynienia z przykładem naśladownictwa, $\mathrm{i}$ to dość miernej roboty.

Dość zgodnie sądzi się, że pojawienie się noży grupy drugiej należy wiązać z dotarciem na obszar Merii fali przybyszów z Rusi północno-zachodniej, którzy przynieśli ze sobą właściwe dla swego warsztatu umiejętności i nawyki produkcyjne (Chomatova 1984, s. 208; Rozanowa 1991, s. 220). Byłyby to zatem wyroby obcego rzemieślnika. Ze względu na chronologię analizowanej serii noży nie wydaje się, aby był nim kowal słowiański, najpewniej wywodzi się on ze środowiska skandynawskiego, docierając na terytorium Merii wraz z kupcem pochodzenia normańskiego.

Z dość podobną sytuacją można się liczyć również w zlewisku Jeziora Białego, na terenie fińskiej Wesi. Przemawiają za tym wyniki badań metaloznawczych 32 noży z osady w Krutik (Chomutova 1984, s. 199 i n.), datowanej na schyłek IX do 3. ćwierci X w. (Sedov 1987, s. 62 i n.; Dubov 1989, s. 90 i n.; Golubeva 1991, s. 148-149). Spotyka się wśród nich okazy o formie typowej dla środowiska fińskiego oraz noże związane z falą przybyszów, wśród których byli niewątpliwie Skandynawowie, przenikający tu z północnego zachodu, w tym być może również z rejonu południowo-wschodniego zlewiska jeziora Ładoga (Sedov [tekst nieczytelny], s. 58; czasami początki obcej kolonizacji tego obszaru wiąże się z napływem ludności z okolic późniejszego Jarosławla; por. Bulkin, Dubov, Lebedev 1978, s. 128 i n.). Ogół noży tej drugiej grupy, [tekst nieczytelny] wyraźnie dominującej, wykonano drogą zgrzewania żelaza i stali (w ponad $90 \%$ były to noże z wkładkami stalowymi typu IV:A:2). W podobny sposób wykuto noże o rodzimej genezie. Przeważają wśród nich okazy żelazne bez śladów dodatkowego utwardzania ostrzy. Towarzyszą [tekst nieczytelny] jednak pojedyncze egzemplarze w sposobie wykonania imitujące technikę typu sandwich. Mamy tu zatem do czynienia - podobnie 
jak w okolicach jeziora Ilmen i Nero - z wyraźnym naśladownictwem obcych technicznie i technologicznie bardziej zaawansowanych wyrobów pro... [tekst nieczytelny] rzemieślnika. Nic jednak nie przemawia za tym, aby w tym czasie był nim kowal słowiański, a tym bardziej fiński. Wówczas podejmowali oni dopiero pierwsze próby opanowania obcych um[iejętności - dop. Red.] wytwórczych. Mogło do tego dojść jednak wyłącznie wskutek stałego kontaktu miejscowych producentów z warsztatem obcego [tekst nieczytelny]. Jest to stwierdzenie niezmiernie istotne, wspiera ono bowiem proponowaną powyżej interpretację analizowanych zbiorów noży, [tekst nieczytelny] których okazów wykonanych w technice typu sandwich nie zaliczono do grupy importów, lecz do wyrobów powstałych na miejscu w kuź[niach - dop. Red.] obcych rzemieślników.

Na tym zakończylibyśmy przegląd materiałów chronologicznie wiązanych w całości lub znacznej części ze starszymi fazami wczesnego średniowiecza. Zdecydowanie liczniejszy jest zasób źródeł z XIII w. Najciekawsze wyniki przyniosły badania metaloznawcze z Nowogrodu Wielkiego, którymi objęto serię liczącą 540 egzemplarzy datowanych na X-XV w. (Kolčin, Janin 1982, s. 119). W naszej [tekst nieczytelny] ograniczymy się jedynie do kolekcji składającej się ze 118 schronologizowanych do końca XIII stulecia (Kolčin 1959, s. 48 i n.). Pochodzą one z poziomów osadniczych dobrze datowanych dzięki badaniom dendrochronologicznym (Kolčin, Černych 1977, s. 105 i n.).

Prawie ogół noży wchodzących w skład tej kolekcji zgrzano z żelaza i stali. W zbiorze chronologicznie najstarszym, datowanym na 2. połowę X do końca XI w., były to wyłącznie okazy żelazne z centralnie umieszczoną wkładką stalową, chociaż sporadycznie i tu spotyka się wśród nich braki, w których warstwę stali zastąpiono prętem żelaznym. W tej starszej fazie rozwoju Nowogrodu w produkcji noży panował zatem niepodzielnie jeden standard technologiczny, typowy dla wysoko wyspecjalizowanego, profesjonalnego rzemieślnika.

Na ogół sądzi się, że w latach 20.-30. XII w. doszło do zasadniczych zmian w technologii tej gałęzi wytwórczości (Kolčin 1959, s. 52 i n.; 1982, s. 164, ryc. 4; 1985, s. 243 i n.; Kolčin, Janin 1982, s. 120). Najpierw pojawiły się noże z klinowatymi wkładkami stalowymi typu IV:B, niewiele zaś później okazy z ostrzami w postaci stalowych nakładek typu IV:C:1. Od schyłku XII w. ten ostatni sposób produkcji absolutnie zdominował warsztat nowogrodzkiego nożownika.

Wyniki uzyskane w Nowogrodzie Wielkim wywarły istotny wpływ na poglądy wielu badaczy dotyczące dziejów kowalstwa na obszarze Rusi Kijowskiej. Zwrócono przede wszystkim uwagę na powszechność występowania w X-XI w. noży wykonanych w technice sandwich. Wcześnie ten sposób produkcji uznano za charakterystyczny dla rzemiosła miejskiego w starszej fazie jego rozwoju, przy czym wytwórcę tej grupy noży identyfikowano zazwyczaj z kowalem słowiańskim, który w wyniku długotrwałego rozwoju, jak sądził B.A. Kolčin (1953), miał opanować technologię zgrzewania żelaza i stali, w tym i szczególnie interesującą nas tu technikę typu sandwich. 
W przypadku Nowogrodu Wielkiego tę etniczną interpretację zdają się wspierać wyniki analizy innych kategorii źródeł. I tak na przykład ocena zabytków wykonanych z metali kolorowych wskazuje na sporadyczną zaledwie obecność Skandynawów w tym ośrodku (Sedova 1981, s. 181, ryc. 13). Ostatnio wyraża się jednak obawy, czy jest to pogląd w pełni zasadny (Nosov 1990, s. 163), Normanowie w X w. mogli zamieszkiwać terytorialnie wyodrębnioną część miasta, dotąd archeologicznie nierozpoznaną. Sugestia ta wydaje się bardzo prawdopodobna.

Przy próbie rozwiązania tej sprawy istotne są również przesłania natury ogólniejszej. W świetle przeprowadzonej niedawno analizy skarbów srebrnych z terenu Rusi północnej okazało się, że około połowy X stulecia związki gospodarcze Skandynawii ze Słowiańszczyzną wschodnią uległy wyraźnemu osłabieniu (Łosiński 1992, s. 144 i n.). W tym czasie mobilne dotąd grupy Waregów zaangażowanych $\mathrm{w}$ handel $\mathrm{z}$ arabskim Wschodem dalsze swe losy powiązały w sposób bardziej trwały z wschodnioeuropejskimi osiedlami wczesnomiejskimi, osiedlając się w nich na stałe. W tej sytuacji szybko mogło dojść do asymilacji i aktualizacji żywiołu normańskiego w miejscowym, słowiańskim środowisku. Wprawdzie też na Rusi północnej proces ten jest dość wyraźnie czytelny w dostępnych obecnie materiałach, począwszy od około połowy X stulecia (Kirpičnikov, Dubov, Lebedev 1986, s. 216 i n., s. 228 i n., s. 235 i n.; Dubov 1989, s. 180 i n.; Petruchin 1983, s. 177 i n.; 1990, s. 207 i n.; inaczej zapatruje się na tę sprawę J.E. Žarnov, który na podstawie materiałów z Gniozdowa wyklucza myśł o możliwości asymilacji Skandynawów w środowisku słowiańskim; patrz Avdusin [red.] 1991, s. 219). Podobnie może być również w Nowogrodzie, a dotyczyć osiadłych tam rzemieślników, w tym i wysoko wykwalifikowanych kowali.

$\mathrm{Z}$ drugiej strony zwraca uwagę wyjątkowo długie utrzymywanie się w Nowogrodzie tradycji skandynawskiego sposobu produkcji noży. Umasowienie się techniki typu IV:C:1 jest tu wyjątkowo późnej daty. Jak pokazują omówione powyżej materiały ze Starej Ładogi i Gniezdowa, noże wykonane w tym standardzie pojawiły się na terenie Rusi północnej stosunkowo wcześnie, najpóźniej u schyłku $\mathrm{X}$ lub na początku XI w. W Nowogrodzie technika typu IV:C:1 nie znalazła jednak wówczas uznania, tam [bowiem - dop. Red.] długo, bo aż do schyłku pierwszej tercji XII stulecia, nadal masowo produkowano noże ze stalowymi wkładkami. Stare tradycje wytwórcze były widocznie zbyt głęboko zakorzenione. Sprzyjało temu zapewne znaczne ograniczenie dopływu nowych fal przybyszów normańskich, którzy przynieśliby ze sobą nowe idee produkcyjne, zadomowione już w tym czasie na terenie Skandynawii. W Nowogrodzie mielibyśmy zatem do czynienia z sytuacją dość zbliżoną do stwierdzonej w anglosasko-skandynawskim Yorku, gdzie stare metody produkcji przetrwały dłużej niż w macierzystych, skandynawskich ośrodkach wytwórczości rzemieślniczej.

Wydaje się, że upowszechnienie się w Nowogrodzie w XII w. techniki produkcji polegającej na łączeniu stalowego ostrza w postaci nakładki z żelaznym grzbietem narzędzia ma też inny niż skandynawski rodowód. Niezmiernie pouczające 
w ocenie tej sprawy są wyniki badań metaloznawczych 92 noży z Suzdala (Rozanova 1991, s. 220, tab. 1-2), założonego na terytorium dawnej Merii, w zasiedleniu której obok osadników z Rusi północno-zachodniej uczestniczyły także plemiona południowego odłamu Słowian Wschodnich (Sedov 1982, s. 190). Badana seria pochodzi z nawarstwień datowanych na XI-XIII w. Szczególnie interesująca jest grupa noży o najstarszej metryce $\mathrm{Z}$ XI stulecia. Wśród okazów zgrzewanych z żelaza i stali najliczniej są reprezentowane noże z wkładkami stalowymi (34,15\%). Współwystępują z nimi jednak, i to w stosunkowo wysokiej frekwencji, noże wykonane w technice typu IV:B (9,76\%) i IV:C:1 (17,07\%). Pojawienie i umasowienie się w Suzdalu tego ostatniego typu zgrzewania żelaza i stali poprzedziłoby zatem w czasie o ponad stulecie podobne zjawisko stwierdzone w Nowogrodzie. Gdyby uznać za słuszny domysł B.A. Kolčina (1953, s. 81; 1975, s. 53 i n.; 1985, s. 243 n.; Kolčin, Janin 1982, s. 118 i n.), a i innych badaczy wyrażających podobny pogląd (por. np. Voznesenskaja, Chomutova 1972, s. 178; Gurin 1987, s. 97; Kočkurkina, Rozanova 1987, s. 92; Zav'jalov 1989a, s. 24; 1989b, s. 174), wiążący umasowienie się standardu typu IV:C:1 z podjęciem produkcji na szeroki rynek, wyznaczającym nowy etap w rozwoju stosunków towarowo-pieniężnych na terenie Rusi, wówczas należałoby Suzdal zaliczyć do ośrodków zdecydowanie bardziej dynamicznie rozwijających się od Nowogrodu. Byłaby to sugestia dość karkołomna. Sprawa wydaje się o wiele prostsza. Suzdal wcześniej od Nowogrodu znalazł się najpewniej w strefie wpływów Rusi południowej, gdzie technikę typu IV:C:1 stosowano już dość powszechnie w X-XI w., a pojawiła się tam ona $\mathrm{w}$ dobie wczesnosłowiańskiej na stanowiskach kultury typu Korčak i Pieńkowka (por. ostatnio Slavjane 1990, s. 387 i n., ryc. 85) ${ }^{17}$.

Interpretację tę zdają się potwierdzać również rezultaty badań metaloznawczych 50 noży z zespołu osadniczego położonego nad rzeką Menka, datowanego na schyłek IX do początku, najpóźniej do połowy XI w. (Gurin 1987, s. 35 i n.). Wokół funkcji tego zespołu toczy się od lat niesłabnąca dyskusja. Według jednych badaczy tam właśnie należy lokalizować najstarszy Mińsk, w źródłach pisanych wzmiankowany jednak dopiero w 1067 r. (Štychov 1978, s. 63 i n.), według innych była to rozległa, ale nieumocniona osada o wiejskim charakterze z nikłymi śladami działalności typu rzemieślniczego (Zagorul'skij 1982, s. 30 i n.). Za słusznością pierwszej z tych koncepcji przemawia zarówno wielkość zespołu, zajmującego wraz z otaczającymi go osadami powierzchnię kilku hektarów, jak i liczny i urozmaicony inwentarz zabytkowy występujący w nawarstwieniach kulturowych. Z sąsiedztwa znane są ponadto trzy skarby monet arabskich (Štychov 1978, s. 64). Mamy tu zatem najpewniej do czynienia z przykładem wczesnego osiedla rzemieślniczo-targowego, uczestniczącego w wymianie dalekosiężnej, być może z najstarszym Mińskiem.

17 Wystąpienie noży wykonanych w technice typu IV:C:1 na stanowiskach tych kultur tłumaczyć zapewne należy przetrwaniem w środowisku wczesnosłowiańskim „czerniachowskich” tradycji wytwórczych (por. uwagi w przypisie 1). 
W kolekcji z osady położonej nad Menką przeważają noże wykute z żelaza i stali. Towarzyszą im egzemplarze o strukturze pasmowej i o nawęglanych ostrzach. Udział okazów zgrzewanych z żelaza i stali wynosi zaledwie 33\%. W tej grupie, obok noży wykonanych $\mathrm{w}$ technice sandwich $(12,5 \%)$, spotyka się także okazy z nakładkami stalowymi typu IV:C:1 (14,5\%). Na Rusi północnej po Suzdalu jest to drugi tak dobrze udokumentowany przykład stanowiska, na którym noże tego ostatniego typu wystąpiły $\mathrm{w}$ tak wysokim odsetku $\mathrm{w}$ zespołach datowanych na X i początek XI w. Można zatem sądzić, że okolice Mińska, położone na południowych peryferiach ziemi połockiej, zaliczały się do tych obszarów, gdzie stosunkowo wcześnie zadomowiły się umiejętności produkcyjne typowe dla warsztatu profesjonalnego kowala związanego ze środowiskiem południoworuskim. Zdecydowanie później, dopiero w XII stuleciu, idea ta dotarła do Nowogrodu Wielkiego. Tam do tego czasu stare tradycje wytwórcze o obcej skandynawskiej genezie decydowały o wyborze techniki produkcji noży.

W świetle przedstawionych powyżej danych wydaje się, że pojawienie się na Rusi północnej techniki typu IV:C:1 było rezultatem kontaktów z dwoma zgoła odmiennymi środowiskami kulturowymi. Jednym z nich była niewątpliwie Skandynawia. Stamtąd umiejętność ta dotarła w 2. połowie lub u schyłku X w. wraz $\mathrm{z}$ ostatnimi falami Waregów. To źródło inspiracji nie spowodowało jednak istotniejszych zmian w warsztacie północnoruskiego kowala. Wskazują na to materiały za Starej Ładogi i Gniozdowa, a zwłaszcza z późniejszego Nowogrodu. Bardziej ważące okazały się idee wytwórcze docierające tu z Rusi południowej, które wcześniej znalazły większe uznanie wszędzie tam, gdzie słabsza była rola podmiotu skandynawskiego, długo kultywującego stare tradycje w warunkach załamania się kontaktów z macierzystymi ośrodkami produkcji kowalskiej. Przywiązanie do starych nawyków wytwórczych okazało się zatem silniejsze od uwarunkowań gospodarczych, którym B.A. Kolčin oddaje palmę pierwszeństwa w procesie umasowienia się na terenie Rusi północnej techniki typu IV:C:1. Wtórnej roli czynników gospodarczych nie można jednak nie doceniać, konieczność uproszczenia zabiegów technologicznych była bowiem wymuszana ciągle rosnącym zapotrzebowaniem rynków lokalnych na wyroby rzemiosła kowalskiego.

Miejscami jednak stare nawyki produkcyjne utrzymały się wyjątkowo długo. Tak było zwłaszcza na obrzeżach Rusi północnej, między innymi w Karelii, zajmującej północno-zachodnią część zlewiska jeziora Ładoga. Terytorium to, nominalnie jedynie wchodzące w skład Rusi, pozostawało pod silnym wpływem oddziaływań gospodarczych i kulturowych Nowogrodu Wielkiego (Sedov 1987, s. 44 i n.). W Karelii, podobnie jak w ośrodku nadilmeńskim, powszechnie stosowano technologię zgrzewania i stali. Potwierdzają to wyniki badań metaloznawczych 43 noży z grodziska Passo (XII-XIII w.) i Tiwersku (XII?-XIV w.). W kolekcjach tych udział okazów zgrzewanych z żelaza i stali jest wyjątkowo wysoki, jak na rangę tych ośrodków, przekracza bowiem 86\% ogółu noży (Kočkurkina, Rozanova 1987, s. 88 i n.). Ze względu na późną chronologię obydwu 
obiektów szczególną uwagę zwraca wysoki odsetek okazów wykonanych w technice typu sandwich. W Passo stanowią one ponad połowę analizowanej kolekcji, w Tiwersku zaś ich liczebność dochodzi do 20\%. Na obszarze Rusi północnej są to jedynie przykłady serii o tak późnej metryce, w których noże żelazne ze stalowymi wkładkami są reprezentowane tak licznie. Można zatem sądzić, że w tej peryferycznie położonej krainie tempo przemian w technologii produkcji kowalskiej było spowolnione, tam dłużej niż gdzie indziej kultywowano stare tradycje produkcyjne, przyniesione tu zapewne przez kowali wywodzących się z Nowogrodu Wielkiego, którzy w tym nowym środowisku dłużej niż w ośrodku macierzystym stosowali dawne metody produkcji.

W świetle ogółu przedstawionych powyżej danych w pełni uzasadniony wydaje się pogląd o skandynawskiej genezie techniki typu sandwich na terenie Rusi północnej. Nosicielami tej metody produkcji noży byli kowale normańscy, którzy wespół z kupcami dotarli na te ziemie już w 2. połowie VIII w., osiedlając się w Starej Ładodze. Stąd wzdłuż szlaków handlu dalekosiężnego przenikali oni w głąb kraju, działając głównie w powstających w tym czasie osiedlach rzemieślniczo-handlowych. Rola rzemieślników nie sprowadzała się jednak wyłącznie do technicznej obsługi kupców, na ich barkach leżały znacznie ważniejsze zadania. Byli oni przede wszystkim producentami wysokojakościowych wyrobów zbywanych wśród miejscowej ludności w zamian za towary stanowiące przedmiot szczególnego zainteresowania kupców. W środowisku północnoruskim towarem tym były zapewne głównie skóry i produkty gospodarki leśnej, a także niewolnicy, dostarczani zarówno na rynki Wschodu, jak i do krajów strefy nadbałtyckiej. Wyroby rzemieślnicze pełniły funkcję ekwiwalentu wymiany, i to - jak sądzę w większym stopniu niż srebro arabskie, które w obrocie towarowym było powszechnie stosowane jako znaki pieniężne jedynie w rejonach znajdujących się w strefie bezpośrednich oddziaływań osiedli rzemieślniczo-handlowych, gdzie wcześnie dochodziło do przełamywania autarkii gospodarczej. Jedynie tam dirhemy pełniły w pełnym tego słowa znaczeniu funkcję środków płatniczych, wkraczając również do obrotu lokalnego, którego zakres wyznaczały potrzeby wynikające z uczestnictwa w handlu dalekosiężnym. Monety arabskie przenikały także na bardziej odległe terytoria, tam jednak długo były one traktowane jako towar, choć o wyjątkowej wartości, ich posiadanie podnosiło bowiem prestiż społeczny właścicieli kruszcu. W życiu codziennym bardziej pożądane były jednak wyroby rzemiosła, takimi zaś przedmiotami były niewątpliwie noże żelazne niezbędne w każdym gospodarstwie domowym. Znajdowały też one powszechny zbyt wśród lokalnych społeczności. Na tym - jak sądzę - polegał mechanizm funkcjonowania w IX-X w. wymiany organizowanej przez obcych kupców działających na rozległych obszarach Rusi północnej. Dobrze tłumaczy to masowy napływ na te tereny rzemieślników skandynawskich, w tym między innymi kowali. Działali zapewne i inni specjaliści, zwłaszcza producenci paciorków szklanych oraz grzebennicy. 
Obcy rzemieślnicy, aktywnie uczestniczący w życiu gospodarczym osiedli wczesnomiejskich, byli zarazem nosicielami umiejętności wytwórczych nieznanych w miejscowym warsztacie. W miarę upływu czasu rodzimy kowal podjął jednak trud przyswojenia sobie obcych mu nawyków produkcyjnych. Nadal jednak działał, i to na szeroką skalę, rzemieślnik pochodzenia normańskiego, którego pozycja zmieniła się dopiero $\mathrm{w} 2$. połowie $\mathrm{X}$ w. wraz z załamaniem się kontaktów gospodarczych Rusi ze Skandynawią. Wówczas to szybko wrastał on w miejscowe środowisko etniczne, z wolna zatracając również świadomość swego pochodzenia. Kultywował on jednak stare nawyki produkcyjne, pokrywając rosnące zapotrzebowanie rynku lokalnego wraz z kształtowaniem się w pełni zurbanizowanych ośrodków miejskich, których byt ekonomiczny w silniejszym niż dotąd stopniu warunkowały związki z zapleczem wiejskim. Na znaczeniu zyskiwała również wymiana między poszczególnymi ziemiami Rusi Kijowskiej, której głównymi ośrodkami życia gospodarczego w X-XII w., obok Nowogrodu Wielkiego, Pskowa, Jarosławla i Rostowa Suzdalskiego na północy, stały się Kijów, Czernihów, Lubecz, Wyszogród i Nowogród Siewierski. Z Południa przenikały też na Północ nowe umiejętności produkcyjne, w tym technika typu IV:C:1. Z wolna wypierała ona stare, bardziej skomplikowane metody produkcyjne, mniej przydatne w warunkach rosnącego zapotrzebowania rynku na wyroby rzemiosła miejskiego. Na Północy tradycyjne metody wytwarzania, o obcej genezie, długo jednak - niezależnie od zmian gospodarczych - znajdowały powszechnie uznanie. Przywiązanie do tradycji było niekiedy silniejsze od uwarunkowań ekonomicznych. Dobrze ilustruje to skalę oddziaływań rzemiosła skandynawskiego na rozwój miejscowej wytwórczości kowalskiej.

Powstaje jednak postawione już powyżej pytanie, czy ogół noży wykonanych $\mathrm{w}$ technice sandwich, pochodzących zwłaszcza z chronologicznie starszych zespołów znalezisk, należy wiązać wyłącznie z działalnością obcego, początkowo głównie wędrownego rzemieślnika. Część noży to być może importy wywodzące się ze skandynawskich ośrodków wytwórczości rzemieślniczej. Ciekawy snop światła na tę sprawę rzuciły wyniki badań składu chemicznego noży wykonanych w technice trójwarstwowego pakietu. Tego rodzaju badanie przeprowadzono na przykładzie materiałów z ziemi połockiej (Gurin 1982, s. 80 i n.; 1984, s. 315 i n. 1987, s. 100 i n.). Okazało się, że wśród noży interesującej nas tu grupy występują między innymi okazy z wkładkami stalowymi o podwyższonej zawartości niklu. Był to niewątpliwie surowiec obcego pochodzenia, domieszki tej nie spotyka się bowiem w rudach darniowych i błotnych na terenie Rusi Północnej. Nikiel występuje natomiast dość często w skandynawskich złożach rud żelaznych, o czym pisałem już powyżej. Obcej proweniencji mogą być zatem również noże wykonane $\mathrm{z}$ takiego materiału. Brak podobnych badań kolekcji z innych stanowisk archeologicznych nie pozwala na ocenę skali tego zjawiska. Można tu zaledwie przypomnieć wyniki dawno już wykonanych ekspertyz materiałów z gniozdowskiego zespołu osadniczego, wśród których część wyrobów żelaznych wykuto z metalu 
o podwyższonej zawartości niklu (Kolčin 1953, 47, tab. 5, s. 136). Wywołało to już wówczas dyskusję na temat pochodzenia przedmiotów żelaznych z tego obiektu (Arne 1962). Może jednak ma rację M.F. Gurin dopuszczający możliwość importu nie tyle gotowych wyrobów, ile raczej stali, w tym również ze Skandynawii. W krajach strefy nadbałtyckiej handel żelazem był w tym czasie zjawiskiem nagminnym, podobnie mogło być zatem również na interesującym nas obszarze. Jest to jednak zaledwie domysł, chociaż bardzo prawdopodobny odnośnie do Gniozdowa, gdzie niewątpliwie działali kowale skandynawscy, wątpliwy natomiast jeśli chodzi o ziemię połocką. Noże wykonane w technice sandwich spotyka się tam co prawda na licznych stanowiskach, z zasady jednak znajdowane są one zaledwie w pojedynczych egzemplarzach, niewiele jest ich również w tak liczących się ośrodkach wytwórczości rzemieślniczej, jak Połock (Gurin 1987, s. 27 i n., ryc. 5:1-15) i Witebsk (Gurin 1987, s. 30 i n., ryc. 6:1-32). Bardziej prawdopodobna wydaje się nam zatem myśl o imporcie gotowych wyrobów niż surowca stalowego. Wyroby te mogły docierać zarówno z pobliskiego Gniozdowa, jak i z centrów gospodarczych położonych na terenie Skandynawii. Stwierdzenie to nie osłabia jednak poprzednio sformułowanej hipotezy o liczącym się udziale kowali skandynawskich w działalności produkcyjnej co najmniej niektórych północnoruskich osiedli rzemieślniczo-handlowych, co tak czytelnie ukazały materiały ze Starej Ładogi, Gniozdowa, Sarskogo gorodišča i Krutik.

Przy przyjęciu tej wykładni wyjaśnienia wymaga kwestia pochodzenia noży wykonanych w technice sandwich, występujących zazwyczaj w pojedynczych jedynie egzemplarzach w zbiorach południoworuskich. Jak wspominaliśmy już powyżej, najstarsze okazy tej grupy znaleziono na stanowiskach kultury volyncevskiej (Slavjane 1990, s. 390) i romeńsko-borszewskiej (Voznesenskaja 1965b, s. 251 i n.; 1979, s. 70 i n.; Slavjane 1990, s. 392). Mieszkańcy ziem, na których rozwijały się te obydwie jednostki kulturowe, utrzymywali bliskie kontakty z ludnością kultury sałtowo-majackiej (Problemy 1978, s. 108 i n., s. 124 i n.; Sedov 1982, s. 137; Slavjane 1990, s. 334; Vinnikov 1990, s. 124 i n.), do powstania której doszło na terytorium władztwa Chazarów (Pletneva 1981, s. 62 i n.; Slavjane 1990, s. 331 i n.). Badania metaloznawcze zabytków żelaznych ze stanowisk tej kultury ujawniły obecność noży zgrzewanych z żelaza i stali, towarzyszących okazom wykutym z żelaza lub ze stali oraz z materiału o strukturze pasmowej (Micheev, Stepan'ka, Fomin 1973, s. 90 i n.; Gopak, Suchobukov 1978, s. 60 i n.; Tolmačeva 1989a, s. 146 i n.; 1989b, s. 107 i n.). Zwłaszcza te ostatnie są tam dość licznie reprezentowane. Wśród okazów zgrzewanych brak natomiast noży wykonanych w klasycznej technice sandwich, chociaż czasami spotyka się egzemplarze o strukturze trójwarstwowej, o nietypowym jednak rozkładzie pasm metalu ${ }^{18}$. Nie wydaje się

${ }_{18}$ Bardzo prawdopodobny jest natomiast udział „sałtowo-majackich” ośrodków wytwórczości rzemieślniczej w upowszechnieniu się na obszarze Rusi południowej techniki typu IV:C:1. Mógł to być drugi po „,czerniachowskim” impuls sprzyjający wprowadzeniu tam tej techniki produkcji. 
zatem, aby noże wykonane w tej technice znane ze stanowisk kultury volyncevskiej i romeńsko-borszewskiej związane były z kręgiem sałtowo-majackim. Mogły one natomiast dotrzeć z Rusi północnej, przenikając na południe szlakiem, którym ku północy przemieszczały się dzięki pośrednictwu Chazarii dwie najstarsze fale srebra kufickiego (Łosiński 1988, s. 96 i n.). Związki Rusi północnej z terytorium kultury sałtowo-majackiej potwierdzają też wywodzące się stamtąd zabytki znajdowane w rejonie Starej Ładogi i w zlewisku jeziora Ilmen (Davidan 1976, s. 115; Dubov 1989, s. 73; Nosov 1990, s. 148; 1991/1992, s. 71, 82; Boguslavskij 1993, s. 140). Kontakty były zatem ożywione, dzięki nim mogły też już u schyłku VIII i w IX w. przenikać daleko na południe wyroby kowali skandynawskich działających w ośrodkach wczesnomiejskich Rusi północnej. Datowanie najstarszych południoworuskich noży wykonanych w technice trójwarstwowego pakietu, przypadających na przełom VIII i IX w. (Slavjane 1990, s. 390), nie stoi w opozycji do tej sugestii. W każdym razie technika ta nie znalazła również i później szerszego zastosowania w produkcji noży na obszarze Rusi południowej. Znane stamtąd z kolekcji datowanych na X-XIII w. nieliczne noże tej grupy to zapewne wyroby wywodzące się z ośrodków rzemieślniczo-handlowych Rusi północnej, chociaż mógł tam działać także obcy rzemieślnik, najpewniej głównie skandynawskiego, a później również słowiańskiego pochodzenia. Z jego obecnością można liczyć się zwłaszcza w Kijowie, gdzie noże wykonane w technice sandwich odnotowano w dość wysokim, jak na stosunki południoworuskie, odsetku około 18\% (Novoe v archeologii 1981, s. 279 i n.).

Podobnie jak na kierunku południowym również ku wschodowi dalej rozchodziły się noże wykonane w technice sandwich. Powszechnie spotyka się je na terytorium zasiedlonym przez Finów nadkamskich, zwłaszcza zaś na obszarze kultury czepieckiej, przypisywanej Udmurtom (Sedov 1987, s. 135 i n.). Na grodzisku w Idna-kar, datowanym na koniec IX-XIII w., okazy interesującej nas tu grupy stanowią ponad 65\% ogółu zbadanych noży (Zav'jalov 1985, s. 37 i n.). Spory ich odsetek $(21 \%)$ to okazy nieudolnie wykonane, najpewniej zatem miejscowe naśladownictwa obcych wyrobów. Produkty lokalnego rzemiosła reprezentują proste standardy technologiczne, były to głównie noże wykute ze stali dymarkowej lub z żelaza, rzadziej zgrzewane z dwóch warstw metalu. Mamy tu zatem do czynienia z sytuacją zbliżoną do dobrze nam znanego z weskiego Krutiku i mariańskiego Sarskogo gorodišča. Na obszarze Udmurtów technika trójwarstwowego pakietu okazała się niezmiernie żywotna, powszechnie stosowano ją jeszcze w końcu XII i w XIII w. Widocznie nie docierały tam, podobnie jak na obszar Karelii, nowe impulsy kulturowe i idee wytwórcze wraz z załamaniem się dalekosiężnego handlu. W wymianie tej Udmurci byli zapewne dostarczycielami przede wszystkim wysokiej klasy łupieży zwierząt futerkowych, które zbywali za wyroby rzemiosła, w części być może sprowadzane, w części zaś - i to zapewne sporej - będące dziełem obcego kowala docierającego wraz z kupcem z ośrodków Rusi północno-zachodniej. Trwałe osadnictwo słowiańskie było tu stosunkowo późnej daty, prak- 
tycznie dopiero w 2. połowie XII w. nabrało ono charakteru bardziej masowego. Sądzi się, że w zasiedleniu tych ziem uczestniczyli głównie kupcy i rzemieślnicy (Dubov 1989, s. 200).

Dość podobnie było również na jeszcze bardziej odległych terytoriach, zamieszkanych przez plemiona fińskie, między innymi w dorzeczu Wyczegdy, gdzie w IX-XIV w. rozwijała się kultura wymska, spadkobierczyni kultury wanwizdińskiej (Sedov 1987, s. 116 i n.). I na tych obszarach odnotowano obecność noży wykonanych w technice sandwich (Zav’jalov, Česnokova 1991, s. 208 i n.). Przypuszcza się, że ta umiejętność zgrzewania żelaza i stali zadomowiła się tam dzięki kontaktom z ziemią nowogrodzką lub też dzięki pośrednictwu ziem położonych w dorzeczu dolnej Kamy. Jej geneza jest w każdym razie obcego pochodzenia.

Możemy zatem przystąpić do próby podsumowania naszych wniosków:

1. Technika typu sandwich ma w krajach Europy odległą tradycję, dopiero jednak w Skandynawii, dzięki jej kontaktom z ośrodkami zachodnioeuropejskimi, przede wszystkim z kręgiem merowińskim, ukonstytuowała się ona jako standard powszechnie stosowany w produkcji noży. Doszło do tego najpewniej w okresie Vendel, w każdym razie w IX-X w. technika ta zdominowała warsztat profesjonalnego rzemieślnika.

2. Dzięki Skandynawom znajomość tej techniki upowszechniła się w wielu krajach ówczesnego świata. Nosicielami tej umiejętności byli normańscy rzemieślnicy, którzy wraz z kupcami przemieszczali się na szlakach wędrówki skandynawskich wikingów, zarówno na zachodnim, jak i na wschodnim kierunku ich penetracji. Dostarczali oni olbrzymiej ilości wyrobów rzemiosła, zbywanych w społecznościach lokalnych w zamian za produkty miejscowej gospodarki. Był to jeden z ważniejszych mechanizmów funkcjonowania gospodarki w okresie rozkwitu handlu dalekosiężnego, organizowanego przez osiedla rzemieślniczo-handlowe, których zasięg działania daleko wykraczał poza środowisko lokalne.

3. Skandynawscy kowale działający w obcym środowisku nie podlegali wpływom miejscowej wytwórczości rzemieślniczej, i to zarówno na obszarach liczących się w dziejach gospodarczych Europy, między innymi na terenach anglosaskiej Anglii, jak i na ziemiach pozostających dotąd na peryferiach dawnego Barbaricum, w tym zwłaszcza położonych w strefie leśnej Europy Wschodniej. Tam wszędzie kontynuowali oni tradycje warsztatu typowe dla macierzystych ośrodków wytwórczości rzemieślniczej.

4. Na obszarach obcych etnicznie, przede wszystkim na terenach gospodarczo mniej zaawansowanych, obecność skandynawskiego rzemieślnika sprzyjała przejmowaniu przez miejscowych kowali umiejętności zgrzewania żelaza i stali w interesującym nas tu wariancie. Z wolna ten sposób produkcji noży stał się zdobyczą wszechobecną w działalności wytwórczej osiedli rzemieślniczo-handlowych. Praktycznie nie jest też możliwa ocena przynależności etnicznej kowali stosujących technikę typu sandwich w późniejszych fazach rozwoju miast wczesnośredniowiecznych. 
5. W Skandynawii u schyłku X w. pojawił się uproszczony standard zgrzewania żelaza i stali typu IV:C:1, z wolna wypierający skomplikowaną technikę sandwich. $\mathrm{Na}$ terenach obcych etnicznie stare nawyki produkcyjne z zasady utrzymały się jednak dłużej, tam kontynuowano tradycyjne sposoby wytwarzania. Załamanie się bliskich kontaktów z ośrodkami macierzystymi, w wyniku osłabienia roli dalekosiężnej wymiany, leżało zapewne u źródeł tego zjawiska. Zmiany wymusiły dopiero czynniki gospodarcze, miejscami jednak długo przetrwały tradycyjne metody produkcji mimo ogólnego postępu w ekonomice, związanego z nowym etapem rozwoju gospodarki towarowo-pieniężnej, ukierunkowanej w znacznym stopniu na wymianę lokalną. Wtórna rola uwarunkowań gospodarczych w dziejach kowalstwa jest tam wszędzie dość wyraźnie czytelna.

6. We wczesnym średniowieczu znajomość techniki typu sandwich nie ograniczała się wyłącznie do krajów skandynawskich i pozostających w kręgu bardziej intensywnych ich zainteresowań. Stosowano ją również w innych częściach ówczesnego świata (por. przypis 2), nigdzie tam jednak technika ta nie stała się standardem tak masowo stosowanym w produkcji noży, jak w rejonach objętych działalnością normańskich wikingów.

Poznań, w listopadzie 1995 r.

\section{ZAŁĄCZNIK NR 1}

\section{Technika i technologia produkcji noży. Próba klasyfikacji}

Badania metaloznawcze noży prowadzone w różnych krajach Europy ujawniły spore zróżnicowanie w technice i technologii wytwórczości tej tak powszechnej formy narzędzia. W literaturze przedmiotu wcześnie też podjęto próbę wydzielenia podstawowych standardów technologicznych stosowanych w produkcji noży w warsztacie wczesnośredniowiecznych kowali. Pierwszą w pełni udaną próbę ich zgeneralizowanej klasyfikacji przedstawił B.A. Kolčin (1953, s. 71 i n.). Do jego ustaleń nawiązywali później nie tylko badacze rosyjscy, białoruscy, ukraińscy, litewscy i estońscy, ale i uczeni z innych krajów Europy, zwłaszcza środkowej i północnej. Z doświadczeń B.A. Kolčina korzystali także badacze polscy. Ze strony nauki polskiej wyszła też próba uporządkowanego i uszczegółowionego systemu klasyfikacji technologii i techniki wykonywania noży. Jej autorem jest J. Piaskowski (1974a, s. 83 i n., ryc. 6), który wydzielił typy, rodzaje, odmiany i klasy technik produkcji noży.

Na podobnych zasadach zbudowano też system, który prezentujemy poniżej. Jest on jednak bardziej rozbudowany, uwzględniający niektóre rzadziej spotykane sposoby produkcji, inne jest też oznakowanie i usystematyzowanie wydzielonych jednostek taksonomicznych. Sądzę, że rekomendowany system podziału jest 
czytelny w odbiorze i dobrze może służyć w procesie analizy materiału źródłowego. Czy jest to przekonanie słuszne, oceni krytyka naukowa, w każdym razie autorowi niniejszych słów służył on lepiej od propozycji zgłoszonej przez J. Piaskowskiego.

W ramach systemu wydzielono następujące jednostki podziału: grupa, typ, odmiana, pododmiana i wariant. Oznakowano je w sposób następujący: grupa - cyfry rzymskie, typ - duże litery alfabetu, odmiana - cyfry arabskie, pododmiana - małe litery, wariant - cyfry arabskie. Wydzielono:

\section{GRUPA I - noże żelazne:}

Typ A - noże wykute $\mathrm{z}$ jednego kawałka metalu:

Odmiana 1:a - noże wykonane z ferrytycznego żelaza ze śladami lokalnego nawęglania pierwotnego,

Odmiana 2 - noże wykonane z pręta żelaznego zgiętego we dwoje w kształcie litery U, wzdłuż osi wzdłużnej głowni.

Typ B - noże zgrzewane $\mathrm{z}$ dwóch lub kilku warstw metalu, w przekroju poprzecznym głowni biegnących wertykalnie:

Odmiana 1 - noże zgrzewane $\mathrm{z}$ dwóch warstw metalu,

Odmiana 2 - noże zgrzewane $\mathrm{z}$ trzech warstw metalu, wykonane $\mathrm{w}$ technice sandwich,

Odmiana 3 - noże zgrzewane z kilku warstw metalu.

Typ C - noże zgrzewane $\mathrm{z}$ dwóch lub kilku warstw metalu, w przekroju poprzecznym głowni rozmieszczonych horyzontalnie lub po skosie:

Odmiana 1 - noże zgrzewane $\mathrm{z}$ dwóch warstw surowca,

Odmiana 2 - noże zgrzewane $\mathrm{z}$ trzech warstw żelaza,

Odmiana 3 - noże zgrzewane z kilku warstw metalu.

Typ D - noże zgrzewane z kilku nieregularnie rozmieszczonych warstw metalu.

GRUPA II - noże stalowe:

Typ A - noże wykute z niskowęglowej stali lub z surowca o nierównomiernym rozkładzie węgla.

Typ B - noże wykute z jednego kawałka średnio- lub wysokowęglowej stali.

Typ C - noże zgrzewane $\mathrm{z}$ dwóch lub trzech warstw stali, w przekroju poprzecznym głowni biegnących wertykalnie:

Odmiana 1 - noże dwuwarstwowe,

Odmiana 2 - noże trójwarstwowe, wykonane techniką sandwich.

Typ D - noże zgrzewane $\mathrm{z}$ dwóch warstw stali, w przekroju poprzecznym głowni biegnących w układzie horyzontalnym lub po skosie.

Typ E - noże zgrzewane z kilku nieregularnie rozmieszczonych warstw stali.

GRUPA III - noże wykonane z surowca o strukturze pasmowej i nierównomiernym rozkładzie węgla i fosforu:

Typ A - noże ,żelazne” o niskiej zawartości węgla i słabym zróżnicowaniu w jego rozkładzie w poszczególnych pasmach metalu. 
Typ B - noże „stalowe” o dużej różnicy w zawartości węgla i fosforu w poszczególnych pasmach metalu.

Według jednych badaczy, a jest ich zdecydowanie przewaga, są to wyroby zgrzewane $\mathrm{z}$ licznych cienkich pasm żelaza i stali lub też wykute ze specjalnie przygotowanego półfabrykatu, czasami również ze złomu metalowego, według innych zaś, do których wśród badaczy polskich zalicza się przede wszystkim J. Piaskowski, struktura pasmowa powstała już w procesie wytopu metalu w wyniku nierównomiernego rozkładu węgla i fosforu, przy czym między tymi dwoma domieszkami dochodziło do korelacji ujemnej. Sprawa jest zatem nadal otwarta, a jej ostateczne wyjaśnienie spoczywa wyłącznie w rękach metaloznawców. Rozstrzygnięć trudno w każdym razie oczekiwać ze strony archeologów.

GRUPA IV - noże zgrzewane $\mathrm{z}$ żelaza i stali:

Typ A - noże zgrzewane $\mathrm{z}$ dwóch lub kilku warstw metalu, w przekroju poprzecznym głowni biegnących wertykalnie:

Odmiana 1:a - noże zgrzewane $\mathrm{z}$ dwóch prętów, [to znaczy - dop. Red.] z warstwy stali i żelaza,

Odmiana 1:b - noże zgrzewane $\mathrm{z}$ warstwy żelaza i stali, przy czym pręt stalowy nie dochodzi do grzbietu noża,

Odmiana 2:a - noże zgrzewane $\mathrm{z}$ trzech warstw metalu, a mianowicie $\mathrm{z}$ centralnie umieszczonej wkładki stalowej i dwóch bocznych warstw żelaza (klasyczny przykład techniki sandwich).

Odmiany 2:b i 2:c - noże z centralną wkładką, wychodzącą na ostrze wykonaną z żelaza (często wysokofosforowego); boczne warstwy tworzą pręty stalowe (odmiana 2:c) lub też pręt żelazny i stalowy (odmiana 2:b). Okazy wykonane $\mathrm{w}$ technice 2:b i 2:c uznaje się zazwyczaj za braki lub wyroby powstałe w warsztacie kowala o niepełnych kwalifikacjach,

Odmiana 3 - noże zgrzewane z 5 warstw żelaza i stali, przy czym wkładkę centralną i dwie boczne warstwy zewnętrzne tworzy metal o podwyższonej zawartości węgla (stal),

Odmiana 4 - noże zgrzewane z 7 warstw, w tym z trzech warstw stali i czterech warstw żelaza. Ostrze narzędzia tworzy centralnie umieszczona wkładka stalowa.

Typ B - noże o żelaznym grzbiecie, w którym osadzone jest stalowe ostrze w postaci klinowatej wkładki, niedochodzącej do tylca narzędzia:

Odmiana 1 - noże z grzbietem wykonanym z jednego kawałka metalu,

Odmiana 2 - noże z grzbietem zgrzanym z dwóch kawałków metalu.

Typ C - noże ze stalowymi nakładkami, tworzącymi ostre narzędzia, zgrzanymi z grzbietem wykutym z jednego lub kilku kawałków metalu, biegnących najczęściej w układzie horyzontalnym lub po skosie:

Odmiana 1 - klasyczne przykłady noży ze stalowymi ostrzami w postaci nakładki; grzbiet wykonany z jednego kawałka metalu. Szew zgrzewczy biegnie najczęściej po skosie (odmiana 1:b), rzadziej prostopadle do osi przekroju poprzecznego głowni (odmiana 1:a). Niekiedy płaszczyzna zgrzewania jest postrzę- 
piona (odmiana 1:c), czasami zaś ukształtowana półkoliście (odmiana 1:e). Spotyka się także nakładki stalowe w postaci litery V (odmiana 1:d) o krótkich (wariant 1:d:1) lub wydłużonych ramionach, dochodzących do tylca (wariant $1: d: 2)$.

Odmiana 2 - noże ze stalowymi nakładkami o grzbiecie zgrzewanym z dwóch kawałków metalu. Są to bądź wyłącznie pręty żelazne (odmiana 2:a), bądź też żelazne i stalowe (odmiana 2:b-c), przy czym warstwa stali umieszczona jest albo w centralnej części głowni (odmiana 2:c), albo też wzdłuż tylca noża (odmiana 2:b). Czasami spotyka się również okazy z warstwą stali zajmująca środkową część głowni, przy czym nakładkę tworzącą ostrze narzędzia wykonano z żelaza (wariant 2:c:2). Wyroby te uznać chyba należy za braki, ten rozkład warstw żelaza i stali nie ma bowiem technicznego uzasadnienia.

Odmiana 3 - noże ze stalowymi nakładkami, tworzącymi ostrze, i z grzbietem zgrzewanym z trzech warstw żelaza i stali, biegnących w układzie horyzontalnym lub po lekkim skosie. Układ warstw stanowił podstawę wydzielenia pododmian a i b.

Odmiana 4 - noże ze stalowymi nakładkami o grzbiecie wykonanym z czterech warstw żelaza i stali lub wyłącznie z żelaza, rozmieszczonych w układzie horyzontalnym w różnej kolejności (pododmiany a-c).

Odmiana 5 - noże ze stalowymi nakładkami o grzbiecie zgrzewanym z wielu warstw żelaza i stali.

Krawędź stalowych nakładek noży odmian 3-5, czasami również odmiany 2, jest z zasady, u jej styku z grzbietową partią noża, ukształtowana faliście, tworząc jakoby zęby. Podobnie też uformowana jest krawędź warstwy metalu, bezpośrednio przylegającej do stalowego ostrza noża. To pasmo metalu wykonane jest z reguły z żelaza o podwyższonej zawartości fosforu.

Typ D - noże ze stalowymi nakładkami o grzbiecie zgrzewanym z dwóch lub kilku kawałków metalu, przy czym szwy zgrzewcze usytuowane są zarówno w układzie pionowym, jak w przypadku noży typu IV:A, jak i w układzie horyzontalnym, jak w przypadku noży typu IV:C. Grzbiety zgrzewane są z dwóch lub kilku warstw metalu, zarówno z żelaza, jak i ze stali (odmiana 1:a-b); czasami warstwa stali tworzy zewnętrzną otulinę żelaznego jądra grzbietu noża (odmiana 1:c).

Typ E - noże dziwerowane z ostrzami w postaci stalowych nakładek. Dziwer tworzy pojedyncze (odmiana 1-2) lub podwójne pasmo (odmiana 3-4). Poszczególne warstwy w grzbietowej części noży, rozmieszczone są w układzie horyzontalnym lub po lekkim skosie, podobnie jak w przypadku noży typu IV:C.

GRUPA V - noże wykute z żelaza i poddane procesowi cementacji. Poszczególne odmiany różni zasięg nawęglania. Czasami obejmuje ono wyłącznie partię ostrza (odmiana 1), czasami ostrze i tylec (odmiana 2), niekiedy zaś utwardzano cały jeden (odmiana 3) lub obydwa boki noża (odmiana 4). Spotyka się także noże wykute z pręta zgiętego wzdłuż osi wzdłużnej w kształcie litery U, uprzednio poddanego jednostronnej cementacji. 


\section{ZAŁĄCZNIK nr 2}

\section{Zestawienie źródel ${ }^{19}$}

\section{Zawartość haseł:}

A: liczebność badanej serii noży (badania metaloznawcze - M, powierzchniowa obserwacja makroskopowa-O),

B: odsetek noży zgrzewanych z żelaza i stali,

C: technika wykonania noży zgrzewanych z żelaza i stali (klasyfikacja według załącznika),

D: literatura,

E: uwagi.

\section{SZWECJA}

1. Helgö, Ekerö sn, Uppland
A: 15 noży (M).
B: $26,67 \%$.
C: IV:A:2 (3 egz.), IV:B (1 egz.), a ponadto m.in. II:C:2 (1? egz.) i II:D:1 (1 egz).
D: Tomtlund 1973, s. 42 i n.; Modin, Pleiner 1978, s. 102 i n.

2. Birka, Uppland
A: 12 noży ( $\mathrm{M}$ - 10 egz., $\mathrm{O}-2$ egz.).
B: $91,67 \%$.
C: IV:A:2 (8 egz.), IV:B (1 egz.), IV:C:1 (1 egz.), a ponadto I:B:2 (1 egz.).
D: Arrhenius 1989, s. 79 i n.

\section{Eketorp III, Öland}
A: 25 noży (M - 24 egz., $\mathrm{O}-1$ egz.).
B: $96 \%$.
C: IV:A:2 (8 egz.), IV:B (7 egz.), IV:C:1 (6 egz.), IV:D (2 egz.), IV:C (1 egz. najpewniej z ząbko- waną wkładką z żelaza wysokofosforowego, osadzoną między ostrzem a grzbietem głowni).
D: Arrhenius 1988, s. 97 i n.
E: nie ustalono techniki produkcji jednego noża za względu na daleko posunięty proces korozji. I ten okaz mógł być zaopatrzony w stalową nakładkę, tworzącą jego ostrze. W tym przypadku ogół noży zaliczałby się do wyrobów zgrzewanych.

\section{Hagestad, Skåne}
A: 2 noże (M).
C: IV:A:2 (1 egz.).
D: Thomson 1968, s. 136, 138.

\section{DANIA}

\section{Lousgaard, Bornholm}
A: 4 noże (M).
C: 2 okazy zgrzewane z żelaza i stali.
D: Jonttijärvi, Lyngstrøm 1990, s. 59 i n.

${ }_{19}$ Od Redakcji: w maszynopisie artykułu znajdują się informacje, na podstawie których należy wnosić, iż Autor planował zilustrować niniejsze zestawienie źródeł mapą. Mapa ta nie została dołączona jednak do maszynopisu artykułu. Brak jej również w archiwum prywatnym prof. W. Łosińskiego, które znajduje się obecnie w Ośrodku Archeologii Średniowiecza Krajów Nadbałtyckich Instytutu Archeologii i Etnologii PAN w Szczecinie. Najprawdopodobniej mapy nie wykonano.

Wśród literatury cytowanej w zestawieniu źródeł znajdują się pozycje, które nie zostały wykazane w bibliografii. 
E: cmentarzysko datowane jest od 2. połowy VI do początku okresu wikińskiego (po 775/800 r.). Noże pochodzą z grobów o bliżej nieustalonej chronologii.

\section{NIEMCY}

\section{Haithabu}
A: 8 noży (M).
B: $37,5 \%$.
C: IV:A:2 (1 egz.), IV:B:2 (1 egz.), IV:C:1 (1 egz.).
D: Pleiner 1983, s. 63 i n.

\section{ANGLIA}

7. York (Coppergate)
A: 50 noży (M), w tym 45 [egz. - dop. Red.] z połowy IX-2. połowy XI w.
B: $79,6 \%$.
C: IV:A:2 (23 egz. - 46,9\%), IV:C:1 (14 egz. - 28,6\%).
D: McDonnell 1989, s. 373 i n.

\section{BIAŁORUŚ, MOŁDOWA, ROSJA, UKRAINA}

\section{Paaso}
A: 23 noże (M).
B: $100 \%$.
C: IV:A:2 (12 egz.), IV:B (8 egz.), IV:C:1 (3 egz.).
D: Kočkurkina, Rozanova 1987, s. 88 i n.

9. Tiversk, Priozerskij rej.
A: 20 noży (M).
B: $70 \%$.
C: IV:A:2 (4 egz.), IV:B (5 egz.), IV:C:1 (5 egz.).
D: Kočkurkina, Rozanova 1987, s. 88 i n.

\section{Staraja Ladoga}
A: 8 noży $(M)$.
B: $87,5 \%$.
C: IV:A:2 (6 egz.), IV:C:1 (1 egz.).
D: Chomutova 1984, s. 208; 1985, s. 216-217.

11. Krasnaja Zarja, Tichvinski rej.
A: 2 noże (O).
C: IV:A:2 (2 egz.).
D: Ravdina 1988, s. 77, nr 108.

\section{Il'ino}
A: 1 nóż $(\mathrm{O})$.
C: IV:A:2.
D: Ravdina 1988, s. 66, nr 88.

13. Ščukovščina, Volchovskij rej.
A: 1 nóż $(\mathrm{O})$.
C: IV:A:2.
D: Ravdina 1988, s. 131-132, nr 231.

14. Karlucha, Lodejnopol'skij rej.
A: 1 nóż $(\mathrm{O})$
C: IV:A:2.
D: Ravdina 1988, s. 69-70, nr 94. 
15. Mergino, Lodejnopol'skij rej.
A: 4 noże (M).
C: IV:A:2 (3 egz.), IV:C:1 (1 egz.).
D: Chomutova 1985, s. 208-209.

16. Šangeniči, Lodejnopol'skij rej.
A: 4 noże (M).
C: IV:A:2 (2 egz.), IV: B (1 egz.).
D: Chomutova 1985, s. 210-212.

17. Akulova Gora, Lodejnopol'skij rej.
A: 1 nóż $(\mathrm{M})$.
C: IV:B.
D: Chomutova 1985, s. 213.

18. Kjargino-Garnjaki, Lodejnopol'skij rej.
A: 2 noże (M).
C: IV:C:1 (2 egz.).
D: Chomutova 1985, s. 212.

19. Njubiniči, Lodejnopol'skij rej.
A: 1 nóż (M).
C: IV:A:2.
D: Chomutova 1985, s. 212.

20. Igokiniči [Lodejnopol'skij rej. - dop. Red.]
A: 1 nóż $(\mathrm{M})$.
C: IV:B.
D: Chomutova 1985, s. 213.

21. Południowo-wschodnie zlewisko jeziora Ladoga
A: 3 noże (M).
C: IV:A:2 (3 egz.).
D: Kolčin 1953, s. 220-221, 252 nr 1-3.

\section{Beloeozero}
A: 15 noży (M).
B: $100 \%$.
C: IV:C:1.
D: Kočkurkina, Rozanova 1987, s. 92.

23. Krutik (Gorodišče), Vologodskaja obl.
A: 32 noże (M).
B: $84,4 \%$.
C: IV:A:2 (22 egz.), IV:B (2 egz.), a także I:B:2 (3 egz.).
D: Chomutova 1984, s. 199 i n.

24. Boltinskaja, Vologodskaja obl.
A: 3 noże $(O)$.
C: IV:A:2 (3 egz.).
D: Ravdina 1988, s. 27, nr 18.

25. Volodino, Vologodskaja obl.
A: 2 noże $(\mathrm{O})$. 


\author{
C: IV:A:2 (2 egz.). \\ D: Ravdina 1988, s. 35-36, nr 37.
}

26. Dubino, Vologodskaja obl.
A: 1 nóż $(\mathrm{O})$.
C: IV:A:2.
D: Ravdina 1988, s. 53, nr 66.

27. Vladimirskoe, Jaroslavskaja obl.
A: 2 noże (O).
C: IV:A:2 (2 egz.).
D: Ravdina 1988, s. 34-35, nr 34.

28. Krivec, Jaroslavskaja obl.
A: 1 nóż (M).
C: brak okazów zgrzewanych z żelaza i stali.
D: Kolčin 1953, s. 80, 254 nr 1.

29. Michajlovskoe, Jaroslavskaja obl.
A: 1 nóż $(\mathrm{M})$
C: IV:A:2.
D: Kolčin 1953, s. 221, 253 nr 1.

30. Vozdvižen'e, Jaroslavskaja obl.
A: 2 noże (O).
C: IV:A:2 (1 lub 2 egz.).
D: Ravdina 1988, s. 35, nr 35.

31. Timerëvo, Jaroslavskaja obl.
A: 1 nóż $(\mathrm{O})$
C: IV: A:2.
D: Ravdina 1988, s. 114, nr 204.

\title{
32. Sarskoe Gorodišče
}
A: 20 noży (M).
B: $50 \%$.
C: IV:A:2 (9 egz.), IV: B (1 egz.), a także I:C:1 (1 egz.).
D: Leont'ev 1976, s. 33 i n.
E: w grupie noży o obcej genezie odsetek okazów zgrzewanych z żelaza i stali (IV:A:2) wynosi $88,9 \%$

\section{Vladimir}
A: 5 noży $(\mathrm{M})$.
C: IV:A:2 (2 egz.), IV:C:1 (2 egz.), w tym jeden typu IV:C:1:d:1, oraz IV:A:1:a (1 egz.).
D: Kolčin 1953, s. 221, 224-225, 253 nr 1-5.

\section{Suzdal'}
A: 92 noże (M).
B: $55,4 \%$.
C: IV:A:2 (22 egz.), IV:B (6 egz.), IV:C:1 (23 egz.).
D: Rozanova 1991, tab. 1-2.

\section{Jaropolč Zalesskij}

A: 45 noży $(\mathrm{M})$. 

B: $35,5 \%$.
C: IV:A:2 (1 egz.), IV:B (5 egz.), IV:C:1 (10 egz.).
D: Chomutova 1978b, s. 147 i n.

\section{Podbolot'e}
A: 1 nóż $(\mathrm{M})$.
C: IV:C:1 (?).
D: Kolčin 1953, s. 225, 255 nr 1.

37. Maksimovka, Vladimirskaja obl.
A: 2 noże (M, O).
C: IV:A:2 (1 egz.)
D: Kolčin 1953, s. 80, 255 nr 1; Ravdina 1988, s. 82, nr 121.

38. Grechov Ručej, Jaroslavskaja obl.
A: 2 noże $(\mathrm{O})$.
C: IV:A:2 (2 egz.).
D: Ravdina 1988, s. 49, nr 58.

39. Pleškovo, Kalininskaja obl.
A: 1 nóż $(\mathrm{O})$
C: IV:A:2.
D: Ravdina 1988, s. 99, nr 165.

40. Gliniki, Kalininskaja obl.
A: 1 nóż $(\mathrm{O})$.
C: IV:A:2.
D: Ravdina 1988, s. 40-41, nr 50.

41. Ust'e, Kalininskaja obl.
A: 1 nóż $(\mathrm{O})$.
C: IV:A:2.
D: Ravdina 1988, s. 120-121, nr 212.

42. Zabor'e, Kalininskaja obl.
A: 1 nóż $(\mathrm{O})$
C: IV:A:2.
D: Ravdina 1988, s. 55, nr 7.

43. Zagor'e, Kalininskaja obl.
A: 3 noże $(O)$.
C: IV:A:2 (3 egz.).
D: Ravdina 1988, s. 55, nr 72.

44. Izbriž'e, Kalininskaja obl.
A: 1 nóż $(\mathrm{O})$
C: IV:A:2.
D: Ravdina 1988, s. 63-66, nr 87.

\section{Evenigorod Moskovskij}
A: 13 noży (M).
B: $84,6 \%$.
C: IV:A:2 (2 egz.), IV:C:1 (9 egz.)
D: Juško, Chomutova 1981, s. 116 i n. 
E: badaniami metaloznawczymi objęto także noże pochodzące z poziomów osadniczych datowanych na XIV-XVII w. Nie uwzględniono ich w zestawieniach statystycznych.

46. Berezoveckij mogil'nik, Kalininskaja obl.
A: 1 nóż $(\mathrm{O})$
C: IV:A:2.
D: Ravdina 1988, s. 25-27, nr 14.

47-49. Cholopij Gorodok, Zolotoe Koleno, Selco, Novgorodskaja obl.
A: 26 noży $(\mathrm{M})$.
C: brak okazów typu IV:A:2; odnotowano natomiast noże wykonane w technice typu I:B:2 (3 egz.) z centralnymi wkładkami z żelaza o podwyższonej zawartości fosforu.
D: Nosov, Rozanova 1989, s. 102 i n.

\section{Novgorod Velikij}
A: 118 noży (M).
B: $98,3 \%$.
C: IV:A:2 (32 egz.), IV:A:3 (4 egz.), IV:C:1 (64 egz.), IV:B (11 egz.), IV:E (1 egz.), a także I:B:2 (5 egz.).
D: Kolčin 1953, s. 79-80, 251 nr 1-9; 1959, s. 48 i n.
E: w powyższym zestawieniu uwzględniono jedynie okazy datowane do końca XIII w.; pominięto natomiast noże pochodzące z poziomów osadniczych o młodszej chronologii.

51. Derevjanicy, Novgorodskaja obl.
A: 1 nóż $(\mathrm{O})$.
C: IV:A:2.
D: Ravdina 1988, s. 50, nr 63.

52. Chreple, Novgorodskaja obl.
A: 1 nóż $(\mathrm{O})$
C: IV:A:2
D: Ravdina 1988, s. 123, nr 217.

53. Novgorodskaja zemlja [ziemia nowogrodzka - dop. Red.] (cmentarzyska)
A: 2 noże (M).
C: IV:C:1 (1 egz.).
D: Kolčin 1953, s. 224, 228, 252 nr 1-2.

54. Samolva, Pskovskaja obl.
A: 1 nóż $(\mathrm{O})$.
C: IV:A:2 (1 egz.).
D: Ravdina 1988, s. 110, nr 189.

\section{Pskov}
A: 9 noży (M).
C:IV:A:2 (2 egz.), IV:C:1 (4 egz., w tym trzy wykonane w technice IV:C:1:d:1).
D: Kolčin 1953, s. 80, 221, 222, 228, 254 nr 1-9.

\section{Izborsk}
A: 29 noży (M).
B: $62,1 \%$
C: IV:A:1 (2 egz.), IV:A:2 (1 egz.), IV:C:1 (15 egz.).
D: Chomutova 1983, s. 30-31. 
57. Lužensko, Vitebskaja obl.
A: 2 noże (M).
C: brak okazów wykonanych w technice IV:A:2.
D: Gurin 1987, s. 57, ryc. 19:27, 28.

\section{Vitebsk / Witebsk}
A: 32 noże (M).
B: $75 \%$.
C: IV:A:1 (1 egz.), IV:A:2 (4 egz.), IV: B (2 egz.), IV:C:1 (15 egz.), IV:C:2 (1 egz.), IV:E (1 egz.).
D: Gurin 1987, s. 30 i n., ryc. 6:1-32.

\section{Polock}
A: 15 noży (M).
B: $47,7 \%$.
C: IV:A:2 (1 egz.), IV:C:1 (5 egz.), IV:D:1:b (1 egz.).
D: Gurin 1987, s. 27 i n., ryc. 5:1-15.

60. Maskoviči, Vitebskaja obl.
A: 126 noży (M).
B: $61,1 \%$.
C: IV:A:2 (1 egz.), IV:B (9 egz.), IV:C:1 (60 egz.). IV:C:2-4 (7 egz.).
D: Gurin 1987, s. 42 i n., ryc. 14:1-26; 15:27-54; 16:55-127; 17:128-153; 18:154-221.

61. Ratjunki, Vitebskaja obl.
A: 8 noży (M).
C: IV:A:2 (1 egz.), IV:C:1 (1 egz.).
D: Gurin 1987, s. 46 i n. ryc. 20:1-8.

62. Postavy, Vitebskaja obl.
A: 1 nóż $(\mathrm{M})$.
C: IV:C:1.
D: Gurin 1987, s. 51, ryc. 19:29.

63. Lesnaja, Vitebskaja obl.
A: 2 noże (M).
C: IV:A:2 (2 egz.).
D: Gurin 1987, s. 51, ryc. 19:30-31.

64. Glinišče, Vitebskaja obl.
A: 1 nóż (M).
C: IV:A:2.
D: Gurin 1987, s. 53, ryc. 20:9.

65. Plusy, Vitebskaja obl.
A: 3 noże (M).
C: IV:A:2 (2 egz.).
D: Gurin 1987, s. 53, ryc. 20:10-12.

66. Slobodka, Vitebskaja obl.
A: 1 nóż $(\mathrm{M})$.
C: IV:A:2.
D: Gurin 1982, tab. 10:322; 1987, s. 54, 102, 136.

67. Zakur'e, Vitebskaja obl.
A: 1 nóż (M) 


\author{
C: IV:A:2 \\ D: Gurin 1982, tab. 10:318; 1987, s. 54, 102, 137.
}

68. Lukoml', Vitebskaja obl.
A: 64 noże (M).
B: $60,9 \%$.
C: IV:A:2 (1 egz.), IV:B (1 egz.), IV:C:1 (35 egz.), IV:C:2-4 (2 egz.).
D: Gurin 1982, tab. 10:319-321; 1987, s. 38 i n., ryc. 11:1-24; 12:25-47; 13:1-20.

69. Bagrinovo, Vitebskaja obl.
A: 1 nóż $(\mathrm{O})$
C: IV:A:2.
D: Ravdina 1988, s. 22, nr 7.

70. Logojsk, Minskaja obl.
A: 7 noży (M).
C: IV:C:1 (3 egz.).
D: Gurin 1987, s. 50, ryc. 19:10-16.

71. Staro-Borisov, Minskaja obl.
A: 6 noży (M).
C: IV:C:1 (3 egz.).
D: Gurin 1987, s. 50-51, ryc. 19:17-22.

\title{
72. Minsk / Mińsk
}
A: 34 noże (M).
B: $58,8 \%$.
C: IV:A:2 (1 egz.), IV:B ( 1 egz.), IV:C:1 (13 egz.), IV:C:2-4 (4 egz.), IV:E? (1 egz.).
D: Gurin 1987, s. 30 i n., ryc. 7:1-34.
E: według Gurina badaniami metaloznawczymi objęto 38 noży; o 4 okazach brak bliższych danych.

73. Stročicy (Menka), Minskaja obl.
A: 48 noży $(\mathrm{M})$.
B: $33,3 \%$.
C: IV:A:1 (1 egz.), IV:A:2 (6 egz.), IV:B (2 egz.), IV:C:1 (7 egz.).
D: Gurin 1982, tab. 10:325-327; 1987, s. 35 i n., ryc. 9:1-33; 10:34-49.

74. Zaslavl', Minskaja obl.
A: 16 noży (M).
B: $81,3 \%$.
C: IV:A:1 ( 3 egz.), IV:A:2 (5 egz.), IV:C:1 (5 egz.).
D: Gurin 1982, tab. 10:323-324; 1987, s. 33 i n., ryc. 8:1-16.

75. Dvorišče, Minskaja obl.
A: 1 nóż (M).
C: brak okazów zgrzewanych z żelaza i stali.
D: Gurin 1987, s. 54, ryc. 20:13.

\section{Volkovysk}
A: 5 noży (M).
C: IV:A:2 (1 egz.), IV:B (1 egz.), IV:C:1 (3 egz.).
D: Voznesenskaja, Chomutova 1972, s. 177 i n.

77. Višenki, Černigovskaja obl.
A: 1 nóż (M). 
C: brak okazów zgrzewanych z żelaza i stali.

D: Kolčin 1953, s. 228, 257 nr 1.

78. Rogačev, Gomel'skaja obl.
A: 1 nóż $(M)$.
C: IV:A:2.
D: Gurin 1982, tab. 10:300.

79. Čaplin, Gomel'skaja obl.
A: 5 noży $(M)$.
C: IV:A:2 (2 egz.), IV:C:3 (1 egz.).
D: Gurin 1982, tab. 10:261, 264, 274, 282-283.

80. Kopys', Vitebskaja obl.
A: 9 noży (M).
B: $66,7 \%$.
C: IV:C:1 (4 egz.), IV:C:2 (2 egz.).
D: Gurin 1987, s. 49-50, ryc. 19:1-9.

81. Orša, Vitebskaja obl.
A: 4 noże (M).
C: IV:C:1 (1 egz.).
D: Gurin 1987, s. 51, ryc. 19:23-26.

82. Poreč'e, Smolenskaja obl.
A: 1 nóż $(\mathrm{M})$.
C: IV:A:2.
D: Kolčin 1953, s. 221, 253 nr 1.

83. Gnëzdovo, Smolenskaja obl.
A: 42 noże $(\mathrm{M}-41, \mathrm{O}-1)$.
B: $90,5 \%$.
C: IV:A:2 (36 egz., w tym 1 typu I:B:2), IV:B (1 egz.), IV:C:1:d:1 (1 egz.).
D: Kolčin 1953, s. 220-221, 252 nr 1-3; Ravdina 1988, s. 41, nr 5; Puškina, Rozanova 1992, s. 200 i n.; Astaškova, Puškina, Rozanova 1985, s. 55-56.

84. Smolensk / Smoleńsk
A: 15 noży (M).
B: $33,3 \%$.
C: IV:C:1 (5 egz.).
D: Astaškova, Puškina, Rozanova 1985, s. 55-56.

\section{Staraja Rjazan}
A: 95 noży (M).
B: $29,5 \%$.
C: IV:A:2 (1 ewentualnie 2 egz.), IV:B (1 egz.), IV:C:1 (25 egz., w tym 5 okazów wykonanych w technice IV:C:1:d:1).
D: Tolmačeva 1983, s. 245 i n.; Rozanova 1991, s. 211 i n.
E: dalsze cztery noże zbadał B.A. Kolčin (1953, s. 220, 226, 228, 251 nr 1-4), wśród których jeden wykonano w technice IV:A:2. Noży tych nie uwzględniono w zestawieniach statystycznych.

\section{Serensk}
A: 50 noży $(\mathrm{M})$.
B: $58 \%$. 


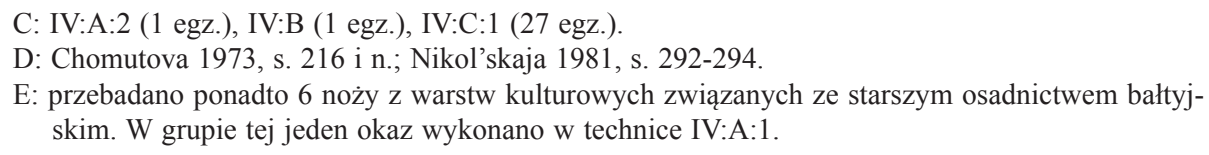

E: przebadano ponadto 6 noży z warstw kulturowych związanych ze starszym osadnictwem bałtyjskim. W grupie tej jeden okaz wykonano w technice IV:A:1.

\section{Fedjaševo}
A: 1 nóż $(\mathrm{M})$.
C: brak okazów zgrzewanych z żelaza i stali.
D: Kolčin 1953, s. 80, 257 nr 1 .

88. Slobodka, Orlovskaja obl.
A: 18 noży $(\mathrm{M})$.
B: $66,7 \%$.
C: IV:B (1egz.), IV:C:1 (11 egz., w tym IV:C:1:d:1).
D: Rozanova 1987, s. 152 i n.

\section{Vščiž}
A: 2 noże (M).
C: IV:C:1 (2 egz.).
D: Kolčin 1953, s. 226, 256 nr 1-2.

90. Starodub, Brjanskaja obl.
A: 1 nóż (M).
C: brak okazów zgrzewanych z żelaza i stali.
D: Voznesenskaja, Kovalenko 1985, s. 105.

91. Rjabcevo, Brianskaja obl.
A: 9 noży (M).
B: $44,4 \%$.
C: IV:A:1 (1 egz.), IV:2 (1 egz.), IV:C:1 (1 egz.), IV:C:2:b (1 egz.).
D: Voznesenskaja, Kovalenko 1985, s. 105-106.

\section{Novgorod Severskij}
A: 19 noży $(\mathrm{M})$.
B: $21,5 \%$.
C: IV:A:2 (1 egz.), IV:C:1 (3 egz., w tym 1 okaz typu IV:C:1:d:1).
D: Voznesenskaja, Kovalenko 1985, s. 96-98.

93. Celikov Bugor, Černigovskaja obl.
A: 3 noże (M).
C: IV:C:1:c (1 egz.).
D: Gopak, Gorjunova 1991, s. 241-242.

94. Sivolož, Černigovskaja obl.
A: 4 noże (M).
C: brak okazów zgrzewanych z żelaza i stali.
D: Voznesenskaja, Kovalenko 1985, s. 100.

95. Blistovo, Černigovskaja obl.
A: 6 noży (M).
C: IV:C:1 (2 egz.).
D: Voznesenskaja, Kovalenko 1985, s. 104.

96. Sednev, Černigovskaja obl.
A: 1 nóż $(\mathrm{O})$. 

C: IV:A:2
D: Ravdina 1988, s. 110-111, nr 190.

97. Sednev, Černigovskaja obl.
A: 1 nóż (M).
C: brak okazów zgrzewanych z żelaza i stali.
D: Voznesenskaja, Kovalenko 1985, s. 99.

98. Sednev, Černigovskaja obl.
A: 2 noże (M).
C: brak okazów zgrzewanych z żelaza i stali typu IV:A:2.
D: Voznesenskaja, Kovalenko 1985, s. 99.

\section{Suberež Černigovskij}
A: ?
C: IV:A:2 (1 egz.), IV:C:1 (3 egz.).
D: Voznesenskaja, Kovalenko 1985, s. 108.
E: brak dokładnych danych na temat liczby noży przekazanych do badań metaloznawczych. Łącznie analizie tego typu poddano 50 zabytków.

100. Malyj Listven, Černigovskaja obl.
A: 1 nóż $(\mathrm{M})$
C: IV:C:2:b
D: Voznesenskaja, Kovalenko 1985, s. 101.

101. Malyj Listven, Černigovskaja obl.
A: 5 noży $(\mathrm{M})$.
C: IV:B (1 egz.), IV:C:1 (1 egz.).
D: Voznesenskaja, Kovalenko 1985, s. 101-102.

\section{Ljubeč}
A: 40 noży (M).
B: $65 \%$.
C: IV:A:2 (3 egz.), IV:B (3 egz.), IV:C:1(20 egz.).
D: Voznesnskaja 1965c, s. 145 i n.; Voznesenskaja, Kovalenko 1985, s. 99; Rozanova 1991, s. 213.

103. Rogošč, Černigovskaja obl.
A: 5 noży (M).
C: IV:C:1 (2 egz.)
D: Voznesenskaja, Kovalenko 1985, s. 100-101.

104. Bobrovica, Černigovskaja obl.
A: 2 noże (M).
C: brak okazów zgrzewanych z żelaza i stali.
D: Voznesenskaja, Kovalenko 1985, s. 103.

105. Šestovicy, Černigovskaja obl.
A: 1 nóż $(\mathrm{O})$.
C: IV:A:2.
D: Ravdina 1988, s. 129-131, nr 229.

106. Morovsk, Černigovskaja obl.
A: 3 noże (M). 
C: IV:C:1 (1 egz.).

D: Voznesenskaja, Kovalenko 1985, s. 100.

107. Lutava, Černigovskaja obl.
A: 5 noży (M).
C: IV:C:1 (1 egz.)
D: Voznesenskaja, Kovalenko 1985, s. 102.

\section{Vyšgorod}
A: 4 noże (M).
C: IV:C:1 (4 egz., w tym IV:C:1:d:1).
D: Kolčin 1953, s. 225, 255 nr 1-4.

\section{Kiev / Kijów}
A: 31 noży (M).
B: $32,3 \%$.
C: IV:A:2, IV:B, IV:C:1.
D: Novoe v archeologii 1981, s. 273, 279 i n.; Kočkurkina, Rozanova 1987; Rozanova 1991, s. 213.

\section{Belgorod}
A: 15 noży $(\mathrm{M})$.
B: $26,7 \%$.
C: IV:A:2 (1 egz.), IV:C:1 (3 egz.).
D: Mezencova, Gopak 1974, s. 73 i n.

111. Korčak, Žitomirskaja obl.
A: 2 noże (M).
C: IV:C:1 (1 egz.).
D: Voznesenskaja 1967, s. 124 i n.; 1978, s. 61 i n.; Slavjane 1990, s. 388.

\section{Teterovka I}
A: 3 noże (M).
C: IV:C:1 (2 egz.).
D: Voznesenskaja 1967, s. 124 i n.; 1978, s. 61 i n.; Slavjane 1990, s. 388.

\section{Rajki}
A: 4 noże (M).
C: IV:C:1 (2 egz.)
D: Kolčin 1953, s. 80, 226, 228, 255 nr 1-4.

\section{Goliki}
A: 3 noże (M).
C: IV:A:2:c (2 egz.).
D: Gopak 1976, s. 46 i n.; 1987, s. 37.

\section{Chrenevka}
A: 4 noże (M).
C: brak okazów zgrzewanych z żelaza i stali.
D: Gopak 1976, s. 46 i n.; 1987, s. 37.

116. Sažki, Vinnickaja obl.
A: 10 noży (M).
C: brak okazów zgrzewanych z żelaza i stali.
D: Gopak 1973, s. 99-100; Gopak, Chavljuk 1973, s. 33 i n. 
117. Červone, Vinnickaja obl.

A: ?

C: brak okazów zgrzewanych z żelaza i stali.

D: Gopak 1973, s. 99-100; 1987, s. 37.

E: brak dokładnych danych na temat liczby noży rozpoznanych pod [względem - dop. Red.] metaloznawczym; wiadomo jedynie, że do badań tego typu wybrano 22 przedmioty żelazne (Gopak 1987, s. 37).

118. Gorodok
A: 5 noży (M).
C: brak noży zgrzewanych z żelaza i stali.
D: Gopak 1976, s. 46 i n.; 1987, s. 37.

\section{Goroševo}
A: 2 noże (M).
C: brak okazów zgrzewanych z żelaza i stali.
D: Gopak 1976, s. 46 i n.; 1987, s. 37.

120. Grinčuk, Chmelnickaja obl.
A: 12 noży (M).
B: $25 \%$.
C: IV:C:1 (2 egz., w tym IV:C:1:d:1) oraz IV:A:1 (1 egz.).
D: Pačkova, Gopak 1981, s. 54 i n.

121. Chanska II, Mołdowa
A: 9 noży (M).
C: brak okazów zgrzewanych z żelaza i stali typu IV:A: 2 , IV:B i IV:C
D: Voznesenskaja 1972b, s. 239 i n.

122-123. Balyko-Ščučina i Ržiščev, Kievskaja obl.
A: 7 noży (M).
C: IV:C:1 (3 egz.).
D: Blaževič, Nedopako, Proleeva 1985, s. 109 i n.

\section{Monastyrek}
A: 7 noży (M).
C: IV:A:1 (1 egz.).
D: Gopak 1976, s. 46 i n.; 1982, s. 100 i n.; 1987, s. 37.

125. Kanevskoe poselenie
A: 14 noży (M).
B: $7,14 \%$.
C: IV:C:1 (1 egz.).
D: Gopak 1975, s. 15 i n.; 1976, s. 46 i n.; 1987, s. 37.

126. Sachnovka, Čerkaskaja obl.
A: 1 nóż (M).
C: brak okazów zgrzewanych z żelaza i stali.
D: Gopak 1975, s. 16; 1987, s. 37.

\section{Knjažaja Gora}
A: 3 noże $(M)$.
C: IC:C:1 (1 egz.)
D: Kolčin 1953, s. 80, 225, 228, 254 nr 1-3. 
E: po badaniach B.A. Kolčina przeanalizowano kolejne 30 przedmioty; patrz Gopak 1987, s. 37. Nie dotarłem do szczegółowszych danych na temat wyników tych badań.

\section{Pastyrskoe gorodišče}
A: 9 noży $(\mathrm{M})$.
C: brak noży zgrzewanych z żelaza i stali.
D: Gopak 1975, s. 15 i n.; 1976, s. 46 i n.; 1987, s. 37.
E: badaniami metaloznawczymi objęto 10 noży; o technologii wykonania wiadomo jednak więcej odnośnie do 9 okazów.

129. Stecovka, Čerkaskaja obl.
A: 2 noże $(\mathrm{M})$.
C: brak okazów zgrzewanych z żelaza i stali.
D: Gopak 1975, s. 15 i n.; 1976, s. 46 i n.; 1987, s. 37; Slavjane 1990, s. 389.
E: wśród nożyc jeden okaz wykonano w technice IV:C.

130. Pen'kovka, Kirovogradskaja obl.
A: 11 noży (M).
B: $9,09 \%$.
C: IV:C:1 (1 egz.).
D: Gopak 1975, s. 15 i n.; 1976, s. 46 i n.; 1987, s. 37.

131. Chitcy, Poltavskaja obl.
A: 8 noży (M).
C: IV:A:1? (1 egz.).
D: Gopak, Gorjunova 1991, s. 238 i n.

132. Mackovka, Poltavskaja obl.
A: 1 nóż (M).
C: brak okazów zgrzewanych z żelaza i stali.
D: Gopak, Gorjunova 1991, s. 240-241.

133. Vovki, Poltavskaja obl.
A: 1 nóż (M).
C: brak okazów z żelaza i stali.
D: Gopak, Gorjunova 1991, s. 242.

134. Volyncevo, Sumskaja obl.
A: ?
C: IV:A:2 ( 1 egz.).
D: Suchobukov, Voznesenskaja, Prijmak 1989, s. 99, 100; Slavjane 1990, s. 390.

135. Gornal', Kurskaja obl.
A: 36 noży $(\mathrm{M})$.
B: $11,11 \%$.
C: IV:A:2 (4 egz.)
D: Voznesenskaja 1979, s. 70 i n.; Slavjane 1990, s. 392.

\section{Kartamyševo I}

A: 1 nóż (M).

C: brak okazów zgrzewanych z żelaza i stali.

D: Gopak, Gorjunova 1991, s. 240.

\section{Dmitrovskoe}
A: 16 noży (M). 

B: $43,75 \%$.
C: IV:A:1 (3 egz.), IV:A:2:c (2 egz.), IV:C:2-4? (2 egz.).
D: Tolmačeva 1989a, s. 151.

138-139. Netajlovka, Verchnij Saltov
A: 10 noży (M).
C: IV:A:1 (2 egz.), IV:B (1 egz.).
D: Gopak, Suchobukov 1987, s. 60 i n.

\section{Jutanovskij mogil’nik}
A: 2 noże $(\mathrm{M})$.
C: IV:C:1 (1 egz.).
D: Tolmačeva 1989a, s. 146 i n.; 1989b, s. 107 i n.

\section{Nižne-Lubjanskoe}
A: 9 noży (M).
C: IV:A:1 (1 egz.), IV:C:1 (1 egz.).
D: Tolmačeva 1989a, s. 151.

\section{Majackoe}
A: 13 noży (M).
C: IV:A:1 (1 egz.), IV:C (2 egz.).
D: Tolmačeva 1989a, s. 150-151.
E: wśród innych narzędzi wystąpiły okazy wykonane w technice IV:A:1-2.

\section{Titčicha}
A: 20 noży (M).
B: $25 \%$.
C: IV:A:2 (2egz.), IV:C:1 (3 egz.).
D: Voznesenskaja 1965b, s. 251 i n.

144-145. Majaki i Pravoberežnoe Cimljan'skoe gorodišče
A: 44 noże (M).
C: IV:A:1 (2 egz.), a ponadto II:C:1 (5 egz.) i II:E (1 egz.).
D: Micheév, Stepans'ka, Fomin 1973, s. 90 i n.

146. Muromskij gorodok, Kujbyševska obl.
A: 18 noży (M).
B: $66,7 \%$.
C: IV:B ( 6 egz.), IV:C:1 (5 egz.).
D: Tolmačeva 1982, s. 56 i n.

\section{Glazov}
A: 4 noże $(M)$.
C: IV:A:2 (1 egz.), IV:C:1:d:1 (2 egz.).
D: Kolčin 1953, s. 222, 226-228, 255 nr 1-4.

148. Lozym, Syktyvdinskij rej.
A: 14 noży (M).
B: $57,14 \%$.
C: IV:A:2 (5 egz.), IV:A:3 (1 egz.), IV:C:1 (2 egz.), a ponadto I:B:2 (1 egz.).
D: Zav'jalov, Česnokova 1991, s. 208 i n.

149. Idna-kar, Glazovskij rej.
A: 43 noże (M). 
B: $74,4 \%$.

C: IV:A:1 (2egz.), IV:A:2 (28 egz.), IV:A:3 (1 egz.), IV:B (1 egz.).

D: Zav'jalov 1985, s. 37 i n.

\section{LITERATURA}

Alekseev L.V. 1980, Smolenskaja zemla v IX-XIII vv. Očerki istorii Smolenščiny i Vostočnoj Belorussii, Moskva.

Alekseeva E.M., Rozanova L.S., Terechova N.N. 1994, Gorgippija: produkcja železodelatel'nogo $i$ železoobrabotyvajuščego remesla, „Rossijskaja Archeologija”, No 3, s. 157-176.

Ambrosiani B., Arrhenius B., Danielsson K., Kyhlberg O., Werner G. 1973, Birka. Svarta jordens hamnoråde. Arkeologisk undersökning 1970-1971, Stockholm.

Ambrosiani B., Clarke H. (red.) 1992, Early Investigations and Future Plans. Investigations in the Black Earth, vol. 1, Stockholm.

Antejn A.K. 1973, Damasskaja stal 'v stranach bassejna Baltijskogo morja, Riga.

Arne T.J. 1962, Was bedeutet das Vorkommen von Nickel in frühgeschichtlichen eisernen Gegenständen?, „Fornvännen“, vol. 57, s. 335-337.

Arrhenius B. 1988, Knives from Eketorp. An evidence of the growing influence of the centralized production from medieval town communities, „Laborativ Arkeologi“, vol. 3, s. 97-124.

- 1989, Arbeitsmesser aus den Gräbern von Birka. Mit einem Appendix, w: Birka II:3. Systematische Analysen der Gräberfunde, Stockholm, 79-92.

Arrhenius O. 1959, Die Grundlagen unserer älteren Eisenherstellung, „Antikvariskt Arkiv“, vol. 13, s. 1-46.

Artamonov M.I. 1990, Pervye stranicy russkoj istorii v archeologičeskom osviščenii, „Sovetskaja Archeologija", No 3, s. 271-290.

Astaškova N.I., Puškina T.A., Rozanova L.S. 1985, Sravnitel'nyj analiz technologii železoobrabotki Gnëzdova i Smolenska (k probleme vozniknovenija goroda), w: Archeologija i istorija Pskova i Pskovskoj zemli, Pskov, s. 55-56.

Avdusin D.A. (red.) 1991, Smolensk i Gnëzdovo (k istorii drevnerusskogo goroda), Moskva.

Baran V.D., Gopak V.D. 1986, Zalizni virobi z poselennja černjachivskoi kul'turi poblizu s Teremci u Pridnistrov'i, „Archeologija”, vol. 55, s. 68-76.

Beleckij S.V. 1993, Drevnij Pskov po danny archeologii, w: Drevnosti Severo-Zapada Rossii, Sankt-Peterburg, s. 78-97.

Bgažda O.C., Terechova N.N., Rozanova L.S. 1990, Kuznečnye izdelija iz pamjatnikov cebel'dinskoj kul'tury, „Sovetskaja Archeologija”, № 3, s. 184-195.

Biborski M. 1978, Miecze z okresu wpływów rzymskich na obszarze kultury przeworskiej, „Materiały Archeologiczne", t. 18, s. 53-165.

Biborski M., Kaczanowski P., Kędzierski Z., Stępiński J. 1982a, Metallographische Untersuchungen als Kriterium einer Identifikation römischer Schweter, w: J. Piaskowski, M. Biborski (red.), Ancient Iron Manufacture Centres in Northern Central Europe. Archaeologia Interregionalis, Kraków, s. 65-98.

1982b, Miecze obosieczne z cmentarzysk kultury przeworskiej w Chmielowie Piaskowym, woj. Kielce, i Gaci, woj. Przemyśl, w świetle analizy archeologicznej i badań metaloznawczych, „Sprawozdania Archeologiczne", t. 33, s. 99-133.

BIRKA I: 1940, H. Arbman, Birka I. Die Gräber. Tafeln, Uppsala.

I: 1943, H. Arbman, Birka I. Die Gräber. Text, Uppsala.

II:/1: 1984, G. Arwidsson (red.), Birka II:1. Systematische Analysen der Gräberfunde, Stockholm.

II/2: 1986, G. Arwidsson (red.), Birka II:2. Systematische Analysen der Gräberfunde, Stockholm.

II/3: 1989, G. Arwidsson (red.), Birka II:3. Systematische Analysen der Gräberfunde, Stockholm.

III: 1938, A. Geijer, Birka III. Die Textilfunde aus den Gräbern, Stockholm.

IV: 1980, A.S. Gräslund, Birka IV. The Burial Customs. A study of the graves on Björkö, Stockholm.

V: 1985, W. Duczko, Birka V. The Filigree and Granulation Work of the Viking Period, Stockholm. 
Björkenstam N., Magnusson G. 1989, Ore as a factor for the development of the indirect process, w: Dal basso fuoco all'altoforno, Varese, s. 83-103.

Boguslavskij O.I. 1993, Južnoe Priladož’e v sisteme transevrazijskich svjazej IX-XII vv., w: Drevnosti Severo-Zapada Rossii (slavjano-finno-ugorskoe vzaimodejstvie, russkie goroda Baltiku), Sankt-Peterburg, s. 132-157.

Borg K. 1976, Bebauungsplan und Bauweise der Burg Eketorp im frühen Mittelalter, w: G. Svahnström (red.), Häuser und Höfe der handeltreibenden Bevölkerung im Ostseegebiet und im Norden vor 1500, Visby (,Acta Visbyensia“, vol. 5), s. 203-218.

Böhne C. 1963, Die Technik der damaszierten Schwerter, „Archiv für das Eisenhüttenwesen“, vol. 34, s. $227-234$.

Böhne C., Dannheimer H. 1961, Studien an Wurmbuntklingen des frühen Mittelalters, „Bayerische Vorgeschichtsablätter", vol. 26, s. 107-122.

Bühler H.E., Strassburger Ch. 1966, Werkstoffkundliche Untersuchungen an zwei fränkischen Schwertern aus dem 9. Jahrhundert, „Archiv für das Eisenhüttenwesen“, vol. 37, s. 613-619.

Bulkin V.A., Dubov I.V, Lebedev G.S. 1978, Archeologičeskie pamjatniki Drevnej Rusi IX-XI vekov, Leningrad.

Callmer J. 1977, Trade beads and bead trade in Scandinavia ca. 800-1000, Lund.

- 1988, Slawisch-skandinavische Kontakte am Beispiel der slawischen Keramik in Skandinavien während des 8. und 9. Jahrhunderts, "69. Bericht der Römisch-Germanischen Kommission", s. 654-674.

- 1994 Early urbanism in Southern Scandinavia ca. 700-1100 AD. Trading places, central settlements and new model centres in continuity and change, „Archaeologia Polona“, t. 32, s. 73-93.

Campbell B. 1995, Ekologia człowieka. Historia naszego miejsca w przyrodzie od prehistorii do czasów wspótczesnych, Warszawa.

Clarke H. (red.) 1979, Iron and Man in Prehistoric Sweden, Stockholm.

Clarke H., Ambrosiani B. 1991, Towns in the Viling Age, Leicester-London.

Chomutova L.S. 1973, Technika kuznečnogo remesla v drevneruskom gorode Serenske (vtoraja polovina $X I I-X I V$ v.), „Sovetskaja Archeologija”, № 2, s. 216-224.

- 1978a. Metallobrabotka na poselenijach D’jakovskoj kultury, „Sovetskaja Archeologija”, № 2, s. $62-77$

- 1978b, Rezul'taty mikrostrukturnogo issledovanija kuznečnych izdelii, w: M.V. Sedova, Jaropolč Zalesskij, Moskva, s. 147-150.

- 1984, Kuznečnaja technika na Zemle drevnej vesi v X v. (po materialam poselenija $u$ d. Gorodišče), „Sovetskaja Archeologija”, No 1, s. 199-209.

- 1985, Metallografičeskoe issledovanie struktury železnych veščej iz kurganov Jugo-Vostočnogo Priladož’ja, w: S.I. Kočkurkina, A.M. Linovskij, Kurgany letopisnoj vesi X-načala XIII v., Petrozavodsk, s. 207-217.

Davidan O.I. 1976, Stratigrafija nižnego sloja staroladožskogo gorodišča i voprosy datirovki, „Archeologičeskij Sbornik", vol. 17, s. 101-118

D'JAKOVSKAJA KUL'TURA 1974, D'jakovskaja kul tura, Moskva.

Dobrovol'skij I.G., Dubov I.V., Kuz'menko Ju.K. 1981, Klassifikacija i interpretacija graffiti na vostočnych monetach, „Trudy Gosudarstvennogo Ermitaža”, vol. 21, s. 53-77.

- 1991, Graffiti na vostočnych monetach. Drevnaja Rus'i sopredel'nye strany, Leningrad.

Dubov I.V. 1977, Skandinavskie nachodki v Jaroslavskom Povolže, „Skandinavskij Sbornik”, vol. 22, s. $175-186$.

- 1982, Severo-Vostočnaja Rus'v epochu rannego srednevekov'ja (istoriko-archeologičeskie očerki), Leningrad.

- 1988, Jaroslavskoe Povolže v IX-XIII vv. (veduščie issledovateli i osnovnye problemy), w: Slavjano-russkie drevnosti, Leningrad, s. 136-150.

- 1989, Velikij Volžskij put', Leningrad.

Dubynin A.F. 1970, Troickoe gorodišče, w: Drevnee poselenie v Podmoskov'e, Moskva, s. 5-98.

Eckstein D., Schietzel K. 1977, Zur dendrochronologischen Gliederung und Datierung der Baubefunde von Haithabu, w: Bericht über die Ausgrabungen in Haithabu, Bericht 11, Neumünster, s. 141-164. 
EKETORP 1976, Eketorp. Fortification and Settlement on Öland/Sweden, Stockholm.

Ellmers D. 1985, Die Bedeutung der Friesen für die Handelsverbindungen des Ostseeraums bis zur Wikingerzeit, „Acta Visbyensia“, vol. 7, s. 7-54.

Emmerling J. 1972, Technologische Untersuchungen an eisernen Bodenfunde, „Alt-Thüringen“, vol. 12, s. 267-320.

- 1978, Technologische Untersuchungen an kaiserzeitlichen Schwertern aus Buchhain (Buchowien), „Alt-Thüringen“, vol. 15, s. 92-102.

Fechner M.V., Nedošivina N.G. 1987, Etnokul'turnaja charakteristika timerevskogo mogil'nika po materialam pogrebal'nogo inventarja, „Sovetskaja Archeologija“, No 2, s. 70-89.

France-Lanord A. 1949, La fabrication des épées damassées aux époques mérovingiennes et carolingiennes, „Le Pays Gaumais“, vol. 10, s. 19-45.

Gajdukov P.G., Fomin A.V. 1986, Monetnye Nachodki Izborska, „Kratkie Soobščenija”, vol. 183, s. 101-110.

Golubeva L.A. 1991, Litejnoe delo na poselenii Krutik v Belozer'e, w: Materialy po srednevekovoj archeologii Severo-Vostočnoj Rusi, Moskva, s. 148-164.

Gopak V.D. 1984, Koval’ska sprawka u meškanciv Chodosivs’kogo gorodišča na rubež našoi eri, „Archologija", vol. 48, s. 88-92.

Gopak V.D., Chavljuk P.I. 1972, Technologija obrobki zaliza u zarubinec'kich plemen Pivdennogo Pobužžja, „Archeologija”, vol. 6, s. 90-96.

Gopak V.D., Suchobokov O.V. 1978, Pro saltivs'ke zalizoobrobne remeslo, „Archeologija”, vol. 25 , s. $60-70$.

Gopak V.D., Šovkopljas A.M. 1983, Černyj metall zarubineckogo poselenija na Oboloni v Kieve, „Sovetskaja Archeologija", No 4, s. 154-160.

Gopak V.D., Zavernjaev F.M. 1981, Železnyje izdelija Počepskogo selišča, „Sovetskaja Archeologija”, $\mathrm{N}^{\circ} 1$, s. 181-191.

Gurin M.F. 1982, Drevnee železo Belorusskogo Podneprov'ja (I tysjačeletie n.e.), Minsk.

- 1984, Issledovanie trechpolosnych nožej Polockoj zemli, „Slovenská Archeológia“, vol. 32, s. 311-326.

- 1987, Kuznečnoe remeslo Polockoj zemli IX-XIII vv., Minsk

Hall R.A. 1990, Archeological Introduction, w: A.J. Mainman, Anglo-Scandinavian Pottery from 16-22 Coppergate, w: The Archaeology of York, vol. 16, No 5, s. 377-385.

Hansson T., Modin S. 1973, A Metallographic Examination of Some Iron Findings with a High Nickel and Cobalt Content, „Antivariskt Arkiv“, vol. 50, s. 5-23.

HELGÖ I: 1961, Excavation at Helgö I. Report for 1954-1956, Stockholm.

II: 1964, Excavations at Helgö II. Report for 1957-1959, Stockholm.

III: 1970, Excavations at Helgö III. Report for 1960-1964, Stockholm.

IV: 1972, Excavations at Helgö IV: Workshop, Part I, Stockholm.

V: 1978, Excavations at Helgö V. Workshop, Part II, Stockholm.

VI: 1981, Excavations at Helgö VI. The Mälaren Area, Stockholm.

VII: 1981, Excavations at Helgö VII. Glass-Iron-Clay, Stockholm.

IX: 1984, Excavations at Helgö IX. Finds, Features and Functions, Stockholm.

X: 1986, Excavations at Helgö X. Coins, Iron and Gold, Stockholm.

XI: Excavations at Helgö XI, Stockholm.

XII: Excavations at Helgö XIII, Stockholm.

Herrmann J. 1982, Slawen und Wikinger in der Frügeschichte der Ostseevölker, w: J. Herrmann (red.), Wikinger und Slawen. Zur Frügeschichte der Ostseevölker, Berlin, s. 10-148.

- 1988, Zur Struktur von Handel und Handelsplätzen im südwestlichen Ostseegebiet vom 8.-10. Jahrhundert, „69. Bericht der Römisch- Germanischen Kommission“, s. 720-739.

Holmquist Olausson L. 1993, Aspects on Birka. Investigations and surveys 1976-1989, Stockholm.

Holmqvist W. 1974, Helgö, eine Vortform der Stadt?, w: H. Jankuhn, W. Schlesinger, H. Steuer (red.), Vor- und Frühformen der europäischen Stadt im Mittelalter, Teil 2, Göttingen, s. 21-29.

- 1976a, Die Ergebnisse der Grabungen auf Helgö (1954-1974), „Prähistorische Zeitschrift“, vol. 51, s. $127-177$.

- 1976b, Die frühmittelalterliche Siedlung auf Helgö, „Acta Visbyensia“, vol. 5, s. 35-48. 
Horstmann D. 1989, Metallographische Untersuchungen an Saxen mit gezahnter Zwischenlage, „Die Kunde NF“, vol. 40, s. 209-211.

Høeg E. 1952, Mikroskopiske undersøgelser af Vimosesvaerd, „Aarbøger for Nordisk Oldkyndighed og Historie", s. 218-223.

Jankuhn H. 1971, Typen und Funktionen vor- und frühwikingerzeitlicher Handelsplätze im Ostgebiet, Wien.

- 1986, Haithabu. Ein Handelsplatz der Wikingerzeit, wyd. 8, Neumünster.

Jensen S. 1991, Ribe zur Wikingerzeit, Ribe.

Jonttijärvi A., Lyngstrøm H. 1990, Fire maend og deres jernknive - en arkaeologisk/metallurgisk undersøgelse, „Aarbøger for Nordisk Oldkyndighed og Historie“, s. 59-67.

Kaczanowski P. 1992a, Importy broni rzymskiej na obszarze europejskiego Barbaricum, Kraków.

- 1992b, Bemerkungen zu Chronologie des Zustroms römischen Waffenimport in das europäische Barbaricum, w: K. Godłowski, R. Madyda-Legutko (red.), Probleme der relativen und absoluten Chronologie ab Latènezeit bis zum Frühmittelalter, Kraków, s. 171-186.

- 1994, Aus den Forschungen an der territorialen Differenzierung des Zustroms römischer Waffenimporte im Barbaricum, w: C. von Carnap-Bornheim (red.), Beiträge zu römischer und barbarischer Bewaffnung in den ersten vier nachchristlichen Jahrhunderten, Lublin, s. 207-222.

Kędzierski Z., Stępiński J. 1981, Badania metaloznawcze miecza żelaznego z Gostomii, woj. Radom, „Sprawozdania Archeologiczne”, t. 21, s. 65-75.

Kirpičnikov A.N. 1988, Ladoga i Ladožskaja zemlja VIII-XIII vv., w: Slavjano-russkie drevnosti, vypusk 1: Istoriko-archeologičeskoe izučenije Drevnej Rusi, Leningrad, s. 38-79.

Kirpičnikov A.N., Dubov I.V., Lebedev G.S. 1986, Rus'i varjagi (russko-skandinavskie otnošenija domongol'skogo vremenii), w: Slavjane i skandinavy, Moskva, s. 189-297.

Kočkurkina S.I., Rozanova L.S. 1987, Itogi technologičeskogo izučenija kuznečnoj produkcii Drevnej Karely (po materialam gorodišč Paaso i Tiversk), „Kratkie Soobščenija”, vol. 190, s. 88-94.

Kolčin B.A. 1953, Černaja metallurgija i metalloobrabotka v Drevnej Rusi, Moskva.

- 1959, Železoobrabatyvajuščee remeslo Novgoroda Velikogo, w: Trudy Novogorodskoj Archeologičeskoj Ekspedicii, vol. 2, Moskva, s. 7-120.

- 1975, Stanovlenie remesla drevnego Novgoroda, w: Tezisy dokladov Sovetskoj delegacii na III Meždunarodnyj Kongress Slavjanskoj Archeologii, Moskva, s. 53-58.

- 1982, Chronogija novogrodskich drevnostej, w: Novgorodskij sbornik. 50 let raskopok Novgoroda, Moskva, s. 156-177.

- 1985, Remeslo, w: B.A. Kolčin (red.), Drevnjaja Rus'. Gorod, zamok, selo, Moskva, s. 243-297.

Kolčin B.A., Černych N.B. 1977, Dendrochronologija Vostočnoj Evropy, Moskva.

Kolčin B.A., Janin V.L. 1982, Archeologii Novgoroda 50 let, w: Novgorodskij sbornik. 50 let raskopok Novgoroda, Moskva, s. 3-136

Kulakov V.I., Tolmačeva M.M. 1987, Technologija izgotovlenija kopii prussov, „Kratkie Soobščenija”, vol. 190, s. 94-101.

Leciejewicz L. 1963, Z badań nad poczatkami osad miejskich nad Bałtykiem we wczesnym średniowie$c z u$, ,Archeologia Polski”, t. 8, s. 332-345.

- 1979, Normanowie, Wrocław.

Leont'ev A.E. 1974, O vremenii vozniknovenija Sarskogo gorodišča, „Vestnik Moskovskogo Universiteta", vol. 29, No 5 , s. 68-74.

- 1976, Klassifikacija nožej Sarskogo gorodišča, „Sovetskaja Archeologija”, № 2, s. 33-45.

- 1981, Skandinavskie vešči v kollekcii Sarskogo gorodišča, „Skandinavskij Sbornik”, vol. 26, s. 141-150.

- 1987, Rostov. Prednosylki voznikonovenija drevnerusskogo goroda, w: Trudy V Meždunarodnogo Kongressa Slavjanskoj Archeologii, vol. 1, № 2a, Moskva, s. 151-157.

Leont'ev A.E., Rjabinin E.A. 1980, Etapy i formy assimiljacii letopisnoj meri (postanovka voprosa), „Sovetskaja Archeologija”, No 2, s. 67-79.

Linder Welin U.S. 1973, Myntbestämningar, w: B. Ambrosiani, B. Arrhenius, K. Danielsson, O. Kyhlberg, G. Werner, Birka. Svarta jordens hamnområde. Arkeologisk undersökning 1970-1971, Stockholm, s. 197-199. 
Lipoński W. 1995, Narodziny cywilizacji Wysp Brytyjskich, Poznań.

Lund Hansen U. 1994, Zum Verhältnis von zivilem Und militärischem Import in der römischen Kaiserzeit, w: C. von Carnap-Bornheim (red.), Beiträge zu römischer und barbarischer Bewaffung in den ersten vier nachchristlichen Jahrhunderten, Lublin, s. 189-206.

Lundsrtöm A. 1968, Helgö als frühmittelalterlicher Handelsplatz in Mittelschweden, „Frümittelalterliche Studien“, vol. 2, s. 278-290.

Lundström A. (red.) 1988, Thirteen Studies on Helgö, Stockholm.

Łosiński W. 1988, Chronologia napływu najstarszej monety arabskiej na terytorium Europy, „Slavia Antiqua“, t. 31, s. 93-181.

- 1992, Miejsce Gniozdowa w rozwoju kontaktów Skandynawii z Rusia Kijowska, „Przegląd Archeologiczny", t. 39, s. 139-152.

- 1995, Zur Genese der frühstädtischen Zentren bei den Ostseeslawen, w: H. Brachmann (red.), Burg - Burgstadt - Stadt. Zur Genese mittelalterlicher nichtagrarischer Zentren in Ostmitteleuropa, Berlin, s. 68-91.

Mamzer H. 1988, Studia nad metalurgia żelaza na terenie pótnocno-wschodniej Butgarii we wczesnym średniowieczu, Wrocław.

McDonnell G. 1989, Iron and its alloys in fifth to eleventh centuries AD in England, „World Archaeology“", vol. 20, № 3, s. 373-380.

Mezencova G.G., Gopak V.D. 1974, Zalizni wyroby z starodavnego Belgoroda, „Archeologija”, vol. 14, s. 73-81.

Micheév V.K., Stepans'ka R.B., Fomin L.D. 1973, Noži saltiv'koi kul turi ta ich virobnictvo, „Archeologija“, vol. 9, s. 90-99.

Minasjan P.S. 1980, Četyre gruppy nožej Vostočnoj Evropy epochi rannego srednevekov'ja (k voprosu o pojavlenii slavjanskich form v lesnoj zone), „Archeologičeskij Sbornik”, vol. 21, s. 68-74.

Mocja O.P. 1990, Pochovannja skandinaviv na Pivdni Kiivs'koi Rusi, „Archeologija”, vol. 4, s. 90-97.

Modin S., Pleiner R. 1978, The metallographic examinations of locks, keys and tools, w: Excavations at Helgö V:1, Stockholm, s. 81-109.

Müller-Wille M. 1973, Eisengeräte aus Haithabu (Ausgrabungen 1963-1964), w: Bericht über die Ausgrabungen in Haithabu, Bericht 6, Neumünster, s. 23-37.

- 1980, Ein Barrenhort aus Haithabu, „Offa“, vol. 37, s. 129-145.

Nedošivina N.G., Fechner M.V. 1985, Pogrebal'nyj obrjad timerevskogo mogil'nika, „Sovetskaja Archeologija“", No2, s. 101-115.

Neumann B. 1927, Römischer Damaststahl, „Archiv für das Eisenhüttenwesen“, vol. 1/3, s. 241-254.

Nosov E.N. 1990, Novgorodskoe (Rjurikovo) gorodišče, Leningrad.

- 1991/1992, Novye dannye o slavjanskich poselenijach novgorodskoj okrugii, „Slavia Antiqua“, t. 33, s. 65-93.

Nosov E.N., Rozanova L.S. 1989, Technologija obrabotki železa na poselenijach Priil'men 'ja v IX-Xvv., „Kratkie Soobščenija”, vol. 198, s. 102-106.

NOVOE V ARCHEOLOGII 1981, Novoe v archeologii Kieva, Kiev.

Nylén E. 1982, Schwedische Wikingerzeit und frühes Mittelalter, w: J. Herrmann (red.), Wikinger und Slawen. Zur Frühgeschichte der Osteseevölker, Berlin, s. 191-212.

Okulicz-Kozaryn Ł. 1993, Finowie Zachodni, Warszawa.

Petersen J. 1951, Vikingtidens redskaper, Oslo.

Petruchin V.Ja. 1983, Ob osobennostjach slavjano-skandinavskich etničeskich otnošenij v rannefeodal'nyj period (IX-XI vv.), w: Drevnejšie gosudarstva na territorii SSSR. Materialy i issledovanija, 1981 god, Moskva, s. 174-181.

1990, O načal'nych etapach formirovanija drevnerusskoj narodnosti i rasprostranenii nazvanija Rus' $v$ svete dannych pogrebal'nogo obrjada, w: Issledovanija v oblasti balto-slavjanskoj duchovnoj kul'tury. Pogrebal'nyj obrjad, Moskva, s. 207-216.

Piaskowski J. 1959, Metaloznawcze badania wyrobów żelaznych z cmentarzysk ciatopalnych Wielkopolski z okresu halsztackiego, „Fontes Archaeologici Posanienses”, t. 10, s. 202-228.

- 1961, Badania żelaznych wyrobów celtyckich z Larnoczy, Sobociska i Głownina (Dolny Ślask), „Silesia Antiqua”, t. 3, s. 88-102. 
- 1964a, Metaloznawcze badania przedmiotów żelaznych z osady w Nowej Hucie-Mogile z okresu rzymskiego, „Materiały Starożytne”, t. 10, s. 169-186.

- 1964b, Metaloznawcze badania przedmiotów żelaznych z Wyżnego Kubina i Pobedimia (Stowacja), „Acta Archaeologica Carpathica”, t. 6, s. 133-140.

- 1965, Technologia żelaza i stali u starożytnych Celtów, „Z otchłani Wieków”, t. 31, s. 264-268.

- 1969a, Cechy materiatowo-technologiczne wyrobów żelaznych jako kryteria kulturowo-chronologiczne, „Wiadomości Archeologiczne”, t. 34, s. 332-354.

- 1969b, Metallkundliche Untersuchungen an archäologischen Eisengegenständen der vorrömischen Eisen und der römischen Kaiserzeit aus dem Nordosten der DDR, „Ethnographisch-Archäologische Zeitschrift", vol. 10, s. 301-332.

- 1970, Metaloznawcze badania zapinek celtyckich znalezionych na ziemiach Polski, „Archeologia Polski“", t. 15, s. 387-417.

- 1972, Technologia przedmiotów żelaznych ludności kultury łużyckiej i pomorskiej na ziemiach Polski, „Wiadomości Archeologiczne”, t. 37, s. 72-89.

- 1973, Eisen- und Stahltechnologie der Völkerwanderungszeit im Gebiet zwischen Weichsel und Oder, „Antikvariskt Arkiv“, vol. 53, s. 29-41.

- 1974a, Untersuchungen der früh-mittelalterlichen Eisen- und Stahltechnologie der Slawen in den Gebieten zwischen Weichsel und Oder, „Archaeologia Polona“, t. 15, s. 67-96.

- 1974b, O stali damasceńskiej, Wrocław.

- 1974c, Metallkundliche Untersuchungen an Eisengegenständen aus dem Gräberfeld von Környe, „Acta Archaeologica Academiae Scientiarum Hungaricae“, vol. 26, s. 117-130.

- 1981, Technologia żelaza plemion baltyjskich u schytku czasów starożytnych i w początku wczesnego średniowiecza (I w. p.n.e.-VII w. n.e.), „Rocznik Białostocki”, t. 15, s. 11-42.

- 1982, Classification and evaluation of the technological level of ancient and early medieval iron manufacture centres, w: J. Piaskowski, M. Biborski (red.), Ancient Iron Manufacture Centres in Northern Central Europe. Archaeologia Interregionalis, Kraków, s. 7- 27.

- 1983a, Metallographische Untersuchungen zur Eisen- und Stahltechnologie in Haithabu, w: Bericht über die Ausgrabungen in Haithabu, Bericht 18, Neumünster, s. 45-62.

- 1983b, Hypothetische Eigenschaften des Schleswig-Holstein geschmolzenen Rennfeuerreisens, „Offa“, vol. 40, s. 157-162.

- 1987, Projekt klasyfikacji postaci znalezisk żużla i innych pozostałości starożytnego i średniowiecznego wytopu żelaza dymarkowego, „Sprawozdania Archeologiczne“, t. 39, s. 331-337.

- 1991, The Technology of Iron Implements on the Territory of Poland in the Late La Tene and Roman Period (2-1 cent.B.C. - 5 cent.A.D.), ,Materiały Archeologiczne“, t. 26, s. 41-52.

- Pleiner R. 1962, Staré evropské kovářrstvi. Stav metalografického výzkumu, Praha.

- 1967, Die Technologie des Schmiedes in der Grossmährischen Kultur, „Slovenská Archeológia“, vol. 15 , № 1 , s. 77-188.

- 1969, Středověké sídliště s kovárnami u Mutějovic, „Památky Archeologické“, vol. 60, № 2, s. 533-571.

- 1970, Zur Schmiedetechnik im römerzeitlichen Bayern, „Bayerische Vorgeschichtsblätter“, vol. 35, s. $113-141$.

- 1974, K otázce jakosti keltských zbrani na základě hrobevého nálezu z Třebohostic, „Archeologické Rozhledy“, vol. 26, s. 461-467.

- 1975, Eisenschmiede im frühmittelalterlichen Zentraleuropa. Die Wege zur Erforschung eines Handwerkszweiges, „Frühmittelalterlichen Studien“, vol. 9, s. 79-92.

- 1979a, K vývoji slovanské nožǐrské techniky v Čechách, „Archeologické Rozhledy“, vol. 31, s. $245-256$.

- 1979b, Die Technik des Schmiedehandwerks im 13. Jahrhundert im Dorf und in der Stadt, w: H. Jankuhn, R. Wenskus (red.), Geschichtswissenschaft und Archäologie, Sigmaringen, s. 393-410.

- 1982a, Untersuchungen zur Schmiedetechnik auf den keltischen Oppida, „Památky Archeologické“, vol. 73 , s. 86-173.

- 1982b, Exkurs. Techniky kovářské výroby. Metalografické a chemické rozbory, w: M. Richter, Hradišt 'ko u Davle, méstečko ostrovského kláštera, Praha, s. 268-287. 
- 1983, Zur Technik von Messerklingen aus Haithabu, w: Berichte über die Ausgrabungen in Haitha$b u$, Bericht 18, Neumünster, s. 63-92.

- 1989, The Technology of Medieval Blacksmiths in Praque, w: Dal basso fuoco all'altoforno, Varese, s. 77-82.

- 1993, Die Technologie der Messerherstellung in der frühmittelalterlichen Fürstenburg von Budeč, Böhmen, „Památky Archeologické“, vol. 84, s. 69-92.

- Pleiner R., Plzák F., Quadrat O. 1956, Poznámky k výrobni technice staroslavanských čepelí, „Památky Archeologické“, vol. 47, s. 314-334.

- Pletneva S.A. 1981, Stepi Evrazii v epochu srednevekov'ja, Moskva.

- Pobol' L.D., Gurin M.F. 1979, Metallografični doslidženija zaliznich virobiv z poselennja I tysjačolittja n.e. u Verchn'omu Podniprovï, „Archeologija“, vol. 31, s. 96-103.

- 1980, Metallografičeskie issledovanija železnych izdelii iz Tajmanova Bychovskogo rajona Belorusskij SSR, w: Rapports du III Congrès International d'Archéologie Slave, vol. 2, Bratislava, s. 341-358. PROBLEMY 1978, Problemy etnogeneza slavjan, Kiev.

Puškina T.A., Rozanova L.S. 1992, Kuznečnyje izdelija iz Gnëzdova, „Rossiskaja Archeologija”, №2, s. 200-220.

Randsborg K. 1980, The Wiking Age in Denmark, London.

Ravdina T.V. 1988, Pogrebenija X-XI vv. s monetami na territorii Drevnej Rusi. Katalog, Moskva.

Rjabinin E.A. 1980, Skandinavskij proizvodstvennyj kompleks VIII veka iz Staroj Ladogi, „Skandinavskij Sbornik", vol. 25 , s. 161-178

Rjabinin E.A., Černych N.B. 1988, Stratigrafija, zastrojka i chronologija nižnego sloja Staroladožkogo Zemljannogo gorodišča v svete novych issledovanii, „Sovetskaja Archeologija”, № 1, s. 72-100.

Rosenqvist A.M. 1967/1968, Sverd med klinger ornert med figurer $i$ kooperlegeringer fra eldre jernalder i Universitetets Oldsaksamling, „Årbok“, s. 143-200.

Rozanova L.S. 1987, Izučenie technologii železnych izdelii, w: T.N. Nikol'skaja, Gorodišče Slobodka XII-XIII vv., Moskva, s. 152-161.

- 1991, Kuznečnaja produkcija i technika eё proizvodstva na Severo-Vostoke Rusi v X-XIII vv., w: Materialy po srednevekovoj archeologii Severo-Vostočnoj Rusi, Moskva, s. 202-225.

Rusanova I.P., Symonovič E.A. (red.) 1993, Slavjane i ich sosedi v konce I tysjačeletija do n.e. - pervoj polovine I tysjačeletija n.e., Moskva.

Sacharov A.N. 1980, Diplomatija Drevnej Rusi. IX-pervaja polovina X v., Moskva.

Salin E. 1957, La civilisation mérovingienne, t. 3: Les techniques, Paris.

Schaaber O. 1963, Beiträge zur Frage des nordischen Eisens. Metallkundliche Grundlagen und Untersuchungen an Funden vom Magdalensberg, „Carinthia I“, vol. 153, s. 129-278.

Schnietzel K. 1981, Stand der siedlungsarchäologischen Forschung in Haithabu - Ergebnisse und Probleme, w: Bericht über die Ausgrabungen in Haithabu, Bericht 16, Neumünster.

Schnurbein S., von 1994, Römische Handwerk in der Germania Magna. Diskussionsbeitrag, w: C. von Carnap-Bornheim (red.), Beiträge zu römischer und barbarischer Bewaffnung in den ersten vier nachchristlichen Jahrhunderten, Lublin, s. 377-378.

Schürmann E. 1959, Untersuchungen an Nydam-Schwertern, „Archiv für das Eisenhüttenwesen“, vol. 30, s. 121-126.

Sedov V.V. 1970, Slavjane i plemena jugo-vostočnogo regiona Baltijskogo morja, w: II. Internationaler Kongress für slawische Archäologie, Band I, Berlin, s. 11-23.

- 1982, Vostočnye slavjane v VI-XIII vv., Moskva.

- 1985, Izborsk v 8-10 vekach, w: Novoe v archeologii Pribaltiki i sosednych territorij, Tallin, s. 119-128.

- 1987, Finno-ugry i balty v epochu srednevekov'ja, Moskva.

- 1992, Skandinavische Elemente im frühmittelalterlichen Pskov, „Studia Baltica Stockholmiensia“, vol. 9, s. 143-154.

Sedov V.V. (red.) 1985, Srednevekovaja Ladoga. Novye archeologičeskie otkrytija i issledovanija, Leningrad.

Sedova M.V. 1981, Juvelirnye izdelija drevnego Novgoroda (X-XV vv.), Moskva.

Selling D. 1955, Wikingerzeitliche und frühmittelalterliche Keramik in Schweden, Stockholm.

SLAVJANE 1990, Slavjane Jugo-Vostočnoj Evropy v predgosudarstvennyj period, Kiev. 
Spehr R. 1971, Die Rolle der Eisenverarbeitung in der Wirtschaftsstruktur des Steinsburg- Oppidums, „Archeologické Rozhledy“, vol. 23, s. 486-503.

Stankus J. 1970, Geležies dirbiniu gamybos Lietuvoje V-VIII amžiais technologija, „Lietuvos TSR Mokslu akademijos darbai“, A serija, vol. 3 (34), s. 57-75.

- 1975, Technologija železnych izdeli baltov vo II-XIII vv., w: Tezisy dokladov Sovetskoj delegacii na III Meždunarodnom Kongresse Slavjanskoj Archeologii, Moskva, s. 43-44.

- 1984, Žemaičiu plokštiniu kapinynu geležies, dirbiniu metalografine analize, „Lietuvos Archeologija“, vol. 3, s. 135-141.

- 1985, Issledovanie proizvodstva železa i kuznečnogo dela v Litve, w: Novoe v archeologii Pribaltiki $i$ sosednych territorij, Tallin, s. 131-139.

- 1988, Geležies dirbiniu metalografine analize, „Lietuvos Archeologija“, vol. 6, s. 65-76.

Stenberger M. 1974, Eketorp. Entwicklung und wirtschaftliche Bedeutung, w: H. Jankuhn, W. Schlesinger, H. Steuer (red.), Vor- und Frühformen der europäischen Stadt im Mittelalter, Teil 2, Göttingen, s. 7-18.

Steuer H. 1974, Die Südsiedlung von Haithabu. Studien zur frühmittelalterlichen Keramik im Nordseeküstenbereich und in Schleswig-Holstein, Neumünster.

- 1984, Zur ethnischen Gliederung der Bevölkerung von Haithabu anhand der Gräberfelder, „Offa“, vol. 41, s. 189-212.

Šramko B.A., Fomin L.D., Solncev L.A. 1971, Novye issledovanija techniki obrabotki železa v Skifii, „Sovetskaja Archeologija”, No 4, s. 140-153.

Šramko B.A., Solncev L.A., Fomin L.D. 1963, Technika obrabotki železa v lesostepnoj i stepnoj Skifii, „Sovetskaja Archeologija”, No 4, s. 36-57.

Šramko B.A., Solncev L.A., Stepanskaja R.B., Fomin L.D. 1974, K voprosu o technike izgotovlenija sarmatskich mečej i kinžalov, „Sovetskaja Archeologija”, № 1, s. 181-190.

Štychov G.V. 1978, Goroda Polockoj zemli (IX-XIII vv.), Minsk.

Thomsen R. 1968, Undersøgelse af jernalderslagger og jerngenstande fra Hagestad i Skåne, „Kuml“, s. $124-142$.

- 1971a, Metallografische Untersuchungen an wikingerzeitlichen Eisenbarren aus Haithabu, w: Berichte über die Ausgrabungen in Haithabu, Bericht 5, Neumünster, s. 9-29.

- 1971b, Metallografische Untersuchungen einer wikingerzetlichen Lanzenspitze aus Haithabu, w: Berichte über Ausgrabungen in Haithabu, Bericht 5, s. 58-82.

- 1994, Metallografiske undersøgelser af svaerd og spydspidser fra mosefundene i Illerup og Nydam, „Aarbøger for Nordisk Oldkyndighed og Historie 1992“, s. 281-310.

Thålin L. (Thålin-Bergman L.) 1967, Metallografisk undersökning av ett vendeltida praktsvärd, „Fornvännen“, vol. 62, s. 225-240.

- 1973, Notes on the Ancient Iron Currency Bars of Northern Sweden and the Nickel Alloys of Some Archeological Objects, „Antikvariskt Arkiv“, vol. 50, s. 24-41.

- 1979, Blackmithing in Prehistoric Sweden, w: Iron and Man in Prehistoric Sweden, Stockholm, s. $99-133$.

- 1983, Techniques and Craftsmanship in the Vendel Period, w: Vendel Period Studies, Stockholm, s. $151-162$.

Tolmačeva M.M. 1983, Technologija kuznečnogo remesla Staroj Rjazani, „Sovetskaja Archeologija”, No 1 , s. 245-258.

- 1989a, Technologija obrabotki železa v lesostepnom regione saltovskoj kul'tury, w: Estestvennonaučnyje metody $v$ archeologii, Moskva, s. 146-168.

- 1989b, Kuznečnye izdelija saltovo-majackoj kul 'tury po materialam jutanovskogo mogil'nika, „Kratkie Soobščenija", vol. 198, s. 107-112.

Tomtlund J.E. 1973, Metallographic Investigation of 13 Knives from Helgö, „Antikvariskt Arkiv“, vol. 50, s. 42-63.

Vinnikov A.Z. 1990, Kontakty donskich slavjan s alano-bolgarskim mirom, „Sovetskaja Archeoligija“, No 3, s. 124-137.

Voznesenkaja G.A. 1965a, Metall Trojickogo gorodišča, w: Archeologija i estestvennyje nauki, Moskva, s. 129-139. 
- 1965b, Obrabotka černogo metalla na gorodišče Titčicha, w: A.N. Moskalenko, Grordišče Titčicha, Voronež, s. 251-261.

- 1965c, Stal'nyje noži drevnego Ljubeča, „Kratkije Soobščenija”, vol. 104, s. 145-149.

- 1970a, Obrabotka železa u plemen černiachovskoj kul’tur'e, „Kratkije Soobščenija”, vol. 121, s. 34-38.

- 1970b, Metallografičeskoe issledovanie kuznečnych izdelij Troickogo gorodišča, w: Drevnee poselenie v Podmoskov'e, Moskva, s. 192-199.

- 1972, Technika obrabotki železa i stali, w: Metall černiachovskoj kul 'ury, Moskva, s. 8-49.

- 1979, Technika kuznečnogo proizvodstva u vostočnych slavjan v VIII-X vv., ,Sovetskaja Archeologija", No 2, s. 70-76.

- 1984, Metaloobrabotka na pozdnelatenskom poselenii Galliš-Lovačka, „Sovetskaja Archeologija”, No 4 , s. $163-175$.

Voznesenskaja G.A., Chomutova L.S. 1972, Metallografičeskoe izučenie kuznečnych izdelij drevnnego Volkovyska, w: Belaruskija starožytnasti, Minsk, s. 177-185.

- 1974, Technika i technologia kuznečnogo proizvodstva na gorodišče Marica, „Sovetskaja Archeologija", No 4, s. 180-188.

Voznesenskaja G.A., Kovalenko V.P. 1985, O technike kuznečnogo proizvodstva v gorodach ČernigovoSeverskoj zemli, w: Zemli Južnoj Rusi v XI-XIII vv., Kiev, s. 95-109.

Warnke D. 1988, Frühstädtische Zentren bei den Nordwestslawen, „Fennoscandia Archaeologica”, vol. 5, s. 69-77.

Wietrzichowski F. 1993, Untersuchungen zu den Anfängen des frühmittelalterlichen Seehandels im südlichen Ostseeraum unter besonderer Berücksichtigung der Grabungsergebnisse von Gross Strömkendorf, w: Wismarer Studien zur Archäologie und Geschichte, vol. 3.

WIKINGER 1992, Wikinger - Waräger - Normannen. Die Skandinavier und Europa 800-1200. Ausstellungskatalog, Berlin-Uddevalla.

Zagorul'skij E.M. 1982, Vozniknovenie Minska, Minsk

Zav'jalov V.I. 1985, Noži gorodišča Idna-kar, w: Materialy srednevekovych pamjatnikov Udmurtii, Ustinov, s. 37-47.

- 1989a, O regional'nych različijach v vostočnoevropejskom kuznečnom remesle X-XIV vv., „Kratkie Soobščenija”, vol. 195, s. 20-25.

- 1989b, Technologičeskie schemy železnych nožej X-XIV vv. iz Vostočnoj Evropy, w: Estestvennonaučnye metody $v$ archeologii, Moskva, s. 168-176.

Zav'jalov V.I., Česnokova N.N. 1991, Železnye predmety Lozymskogo poselenija (vanvizdinskaja kul'tura), ,Sovetskaja Archeologija”, No 2, s. 208-216. 
